
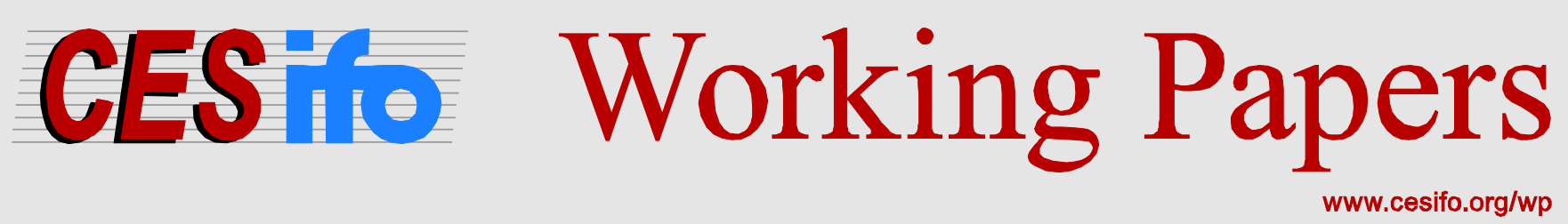

\title{
Minorities, Human Capital and Long-Run Development: Persistence of Armenian and Greek Influence in Turkey
}

\author{
Cemal Eren Arbatli \\ Gunes Gokmen
}

\author{
CESIFO WORKING PAPER NO. 6268 \\ CATEGORY 12: EMPIRICAL AND THEORETICAL METHODS \\ DECEMBER 2016
}

An electronic version of the paper may be downloaded

- from the SSRN website:

- from the RePEc website:

- from the CESifo website:

www.SSRN.com

www.RePEc.org

www.CESifo-group.org/wp 


\title{
Minorities, Human Capital and Long-Run Development: Persistence of Armenian and Greek Influence in Turkey
}

\begin{abstract}
We study the long-term economic legacy of highly-skilled minorities a century after their wholesale expulsion. Using mass expulsions of Armenian and Greek communities of the Ottoman Empire in the early 20th century as a unique natural experiment of history, we show that districts with greater presence of Armenian and Greek minorities at the end of the 19th century are systematically more densely populated, more urbanized, and more developed today. Results are robust to accounting for an extensive set of geographical and historical factors of development and minority settlement patterns. Matching type estimators, instrumental variable regressions, and a sub-province level case study corroborate our findings. Importantly, we provide evidence on the channels of persistence. Armenian and Greek contribution to long-run development is largely mediated by their legacy on local human capital accumulation. In comparison, the mediating effect of minority asset transfer on development appears less important.
\end{abstract}

JEL-Codes: O100, O430, P480, N400, Z120.

Keywords: human capital, economic development, expulsion, minorities, ethnicity, Armenians, Greeks, persistence.

\author{
Cemal Eren Arbatli \\ Faculty of Economic Sciences, NRU \\ Higher School of Economics \\ 26 Shabolovka St. \\ Moscow / Russia \\ earbatli@gmail.com
}

\author{
Gunes Gokmen \\ New Economic School \\ 100 Novaya Street \\ Skolkovo \\ Moscow / Russia \\ gunesgokmen@gmail.com
}

\footnotetext{
November 2016

We thank Daron Acemoglu, Quamrul Ashraf, Sascha Becker, Kristian Behrens, Jeanet Bentzen, Eric Chaney, Nurhan Davutyan, Ruben Enikolopov, Oded Galor, Selim Gulesci, Erik Hornung, Murat Iyigun, Sergei Izmalkov, Grigory Kosenok, Timur Kuran, Andrea Matranga, Stelios Michalopoulos, Timur Natkhov, Ömer Özak, Şevket Pamuk, Maria Petrova, Jean-Philippe Platteau, Dimitra Politi, Nico Voigtländer, Hosny Zoabi; the seminar participants at Brown University, Universityof Copenhagen, Copenhagen Business School, Toulouse School of Economics, Stockholm Institute of Transition Economics, University of Gothenburg, IMT Lucca, New Economic School, Higher School of Economics, and the conference participants at the Econometric Society Meeting, European Economic Association Meeting, CESifo Political Economy Workshop, ASREC, 6th Annual Workshop on Growth, History and Development, Workshop on Institutions, Individual Behavior and Economic Outcomes, Armenian Economic Association, and the Nordic Conference in Development Economics for valuable comments.
} 


\section{Introduction}

The role of productive minorities in the emergence of modern economies and the long-term prosperity of their home locations has been an important subject of study. The literature so far has largely focused on the direct role of Protestant and Jewish communities. ${ }^{1}$ Yet, no empirical study distinguishes the long-term legacy of highly-skilled minorities from their ongoing contribution to local development. In particular, we know little about the influence of highly productive groups on modern development long after they were forced out of their homes en masse. Most post-expulsion studies are based on anecdotal evidence or descriptive historical statistics that do not allow a systematic assessment of minority legacy. This paper fills this gap in the literature.

There are three main determinants of minority footprint on contemporary regional income differences after a long period of absence. First, whether minorities create differences in regional economic potential prior to their expulsions, i.e. the initial conditions, plays an important role. Second, economic forces that may amplify or erode this historical influence in the post-expulsion period are another factor relating to persistence channels. For example, the nature of inter-group interaction and the subsequent human capital spillovers between minorities and the majority could be crucial for the degree of persistence. Finally, under certain conditions, the adverse shock of the expulsion in high-minority regions may unleash economic forces with long-term repercussions. Consequently, how the net effect plays out over the years is an empirical question that, so far, has not been addressed by studies on skilled migration and on the role of human capital for economic development. The goal of this paper is to answer this broad question by utilizing the mass expulsions of Armenian and Greek communities of the Ottoman Empire in the early 20th century as a unique natural experiment of history.

Historical records and anecdotal evidence suggest that Ottoman Armenians and Greeks had higher levels of human capital and wealth, and disproportionately high representation in modern economic sectors. Therefore, until their departure, they arguably had a bigger impact on the development of their home regions than the Muslim majority (Üngör and Polatel, 2011; Kuran,

\footnotetext{
${ }^{1}$ Some of the prominent qualitative work on the subject are Weber et al. (1930); Weber (1968); Sombart (1951); Braudel (1982). For quantitative studies, see, for example, Becker and Woessmann (2009); Hornung (2014); Acemoglu et al. (2011); Waldinger (2012); Botticini and Eckstein (2012b); Spitzer (2015a); Pascali (2016); Johnson and Koyama (2016).
} 
2004a; Der Matossian, 2007; Kévorkian, 2011). ${ }^{2}$ Forced displacement of Armenians from their homelands following the onset of the First World War, and the expulsion of Greek minorities with the Greek-Turkish Population Exchange in 1923 virtually put an end to centuries of cohabitation and socioeconomic interaction between Muslim and non-Muslim subjects of the Ottoman Empire. This historical episode provides us with an ideal setup to empirically assess the long-run legacy of Ottoman Armenians and Greeks on regional development in modern Turkey. ${ }^{3}$

To empirically evaluate long-term minority influence, we exploit novel data with district level variation in the 1893 population shares of Armenians and Greeks prior to their departure, and various proxies for historical and contemporary development in Turkey. We find that districts with greater Armenian and Greek concentration before the expulsions are today more densely populated, more urbanized and enjoy higher economic welfare measured by the intensity of lights at night. ${ }^{4}$ For example, a move from the 10th to the 90th percentile in the historical Armenian share distribution implies an increase in district level luminosity by almost 25 percent, while the same effect is around 32 percent for Greeks. The changes in income at the province level implied by these magnitudes are economically meaningful. Back of the envelope calculations suggest that, conditional on our baseline controls, a modern province with a 20 percent (90th percentile) historical Armenian share is estimated to have 11 percent higher gross regional product per capita in 2000 than a province with no historical Armenian presence; and this effect corresponds to about $\$ 260$ per capita at the average province income. Similarly, a modern province with a 26 percent (90th percentile) historical Greek share is estimated to have more than 14 percent higher gross regional product per capita in 2000 than another province with no historical Greek presence, an effect of more than $\$ 335$ per capita.

Our results hold under alternative specifications and estimation strategies. Firstly, our findings are robust to the inclusion of numerous geographic and climatic factors of economic activity. In addition, we carefully check the sensitivity of the estimates to various potential drivers of

\footnotetext{
${ }^{2}$ For example, commerce was heavily controlled by Armenians in the East and by Greeks in the West. Trade with Europe was almost entirely intermediated by these minorities, and they also dominated the financial sectors. Even craftsmanship was to a large extent a Greek and Armenian occupation.

${ }^{3}$ Unlike the Greeks and Armenians, the Ottoman Jews did not experience a systematic and large scale expulsion. This is the main reason why our analysis is confined to Armenian and Greek legacy. In any case, Jewish population shares and their geographical variation were too small to conduct a meaningful statistical analysis.

${ }^{4}$ Light intensity at night, or luminosity, is a widely used proxy for economic activity when more direct indicators of development are not available at the local level.
} 
historical and contemporary development. The results are also robust to unobserved time-invariant determinants of development at the sub-region and province levels. Altonji et al. (2005) ratios suggest that selection on unobservables would have to be 19.5 and 4.2 times as large as selection on observables to explain away our Armenian and Greek estimates of minority legacy, respectively. Moreover, to have more comparable treatment and control units, we carry out matching type estimations. Importantly, instrumental variable analysis exploiting ancient minority settlement patterns more than two millennia ago confirms our main findings, and thus, gives us more confidence for a causal interpretation. Last but not least, we offer a sub-province level case study of Armenian and Greek influence in Kayseri Province of Turkey. We complement our discussion with a set of regressions that exploit township/village level variations in luminosity, educational attainment and proximity to old minority buildings. This local analysis corroborates our district-level findings.

We explore two potential channels of persistence that may explain our findings. First, minority human capital could have played a role in raising the level of human capital within the Muslim populace. This channel can work either directly, through intergroup human capital spillovers (e.g. diffusion of know-how, expertise, entrepreneurial spirit) during the long co-existence and interaction of the two communities, or more indirectly through the creation of an economic environment with greater returns to human capital. A second channel could be the role of physical capital Armenians and Greeks had accumulated, and the way this capital was redistributed to Muslim population in the aftermath of the expulsions. Confiscation of minority assets might have contributed to wealth concentration and facilitated capital accumulation during the early years of the republic. Thus, the minority capital that was transferred to the local Muslim elite might have facilitated the emergence of a Muslim bourgeoisie and provided a foundation for the creation of a modern national economy (Kévorkian, 2011; Üngör and Polatel, 2011).

Our findings on potential channels suggest that the legacy of Armenians and Greeks on economic development largely operates through their contribution to local human capital of the Muslim population. We show that, in the past, Muslims in historically high-minority areas had greater levels of human capital than Muslims in low-minority areas; and this difference persists to date. Importantly, Sobel-Goodman tests suggest that the human capital channel is highly relevant in mediating the minority influence on current economic activity. In comparison, the mediating 
effect of asset transfer on economic development appears less important. Our case study on Kayseri Province also corroborates the importance of human capital channel.

Besides the usual identification issues such as the endogeneity of the settlement patterns, scholars who aim to isolate the long-term legacy of a particular community often face additional obstacles that relate to migration features. Generally, one main difficulty is partial and selective out-migration. Most migration happens voluntarily, and voluntary migration dynamics depend on the preferences, skills and economic opportunities of emigrants. Even exogenous shocks like conflicts, natural disasters or state policies typically spur involuntary out-migration for only a select sub-group in a given community. In either scenario, as some group members may choose (or be allowed) to stay while others leave, there is no marked end to minority presence. Thus, disentangling the legacy of previous generations from the ongoing effect of the remaining co-ethnics will be difficult. Additionally, as the timing of voluntary migrations typically differs across regions, ${ }^{5}$ so does the duration of treatment, i.e., the period of cohabitation in each region.

Our historical setting is largely immune to these problems. Both Greeks and Armenians were forced to leave their homelands in Anatolia as a result of the official state policies that were motivated partly by the ongoing wars and partly by the ideological orientations of the ruling elite. Implementation was highly uniform: the mass expulsions of Armenians and Greeks led to an almost complete removal of these communities from all the regions of modern Turkey (with the exception of Istanbul) over a short time period (1915-1917 for Armenians and 1919-1923 for Greeks). Around 1893, Armenians and Greeks, respectively, constituted about eight and ten percent of the Ottoman population in the territories that roughly correspond to Turkey today (Karpat, 1985). By 1927, however, 99 percent of Turkey's population was registered as Muslim (excluding Istanbul). ${ }^{6}$ Hence, unlike many other cases, return migration is not an issue to be accounted for in our setting. ${ }^{7}$ More importantly, the fact that none of the regions in our sample was spared from the expulsions allows

\footnotetext{
${ }^{5}$ Spitzer and Zimran (2014); Spitzer (2015b).

${ }^{6}$ One reason was the government law issued in May 1927 which authorized the exclusion of Turkish nationality to anyone who had not taken part in the War of Independence and had remained abroad between 24 July 1923 and 27 May 1927.

${ }^{7}$ Also note that, as of $2016,99.8 \%$ of Turkey is registered as Muslim.
} 
us to use the sub-national variation in the presence of Armenians and Greeks of the late Ottoman period as a proxy for the long-run exposure of each region to minorities. ${ }^{8}$

Any indirect impact of more prosperous ethnic groups on contemporary regional development would presumably be more pronounced when they are more established in their homelands and interact longer with other groups. Thus, another advantage of our setting is that both Armenians and Greeks were more native to their respective homelands in Asia Minor, compared to Turks and other Muslim groups who arrived in the region much later. ${ }^{9}$ Moreover, both communities lived together with Muslims in their respective homelands over a considerably long period of about eight centuries. Also, by conducting a sub-national analysis over a territory ruled by the Ottoman Empire for more than six centuries until the expulsions, and consequently by the Turkish Republic after 1923, we are able to largely avoid the influence of institutional heterogeneity that would plague identification in a cross-national analysis. Finally, since both Armenians and Greeks were sizable communities in the region that were subject to mass expulsions around the same period, we are able to make a reasonable comparison between the two ethnic groups with respect to their long-term legacies on Turkish development.

Taken together, our results bear significance beyond their particular historical context. They suggest that a social and institutional environment that is conducive to peaceful co-existence of different ethno-religious groups can foster beneficial outcomes for the society at large. More specifically, positive human capital externalities and spillovers across groups can have long-lasting effects that go beyond their originators. While a large body of empirical work on ethnic diversity generally points to its adverse consequences at global and national levels, our results seem to lend qualified support to an optimistic view of historical diversity over the long-run.

The next section places the paper in the literature. Section 3 provides information about the economic position and the legal status of Greeks and Armenians in the Ottoman Empire, and offers a brief historical summary of the events leading up to deportations of the Armenians and the Greek-Turkish Population Exchange. Section 4 describes our data and the empirical methodology. Section 5 presents our main findings and the robustness checks, while Section 6 offers evidence on

\footnotetext{
${ }^{8}$ We make the implicit assumption that the ethnic composition in the region was fairly persistent prior to the Ottoman census of 1881-1893, and deviations from the observed ethnic distribution far back in history had a negligible impact on contemporary regional outcomes.

${ }^{9}$ Armenians and Greeks are thought to be settled in the region around 7 th and 8 th century BC, respectively (Khachikyan, 2010; Burckhardt, 1998), whereas Seljuk Turks penetrated the area in the 11th century.
} 
the channels of persistence. Section 7 presents a case study and gives local level evidence. Section 8 concludes the paper.

\section{Related Literature}

Firstly, this paper contributes to the literature on the socioeconomic and political legacy of various ethno-religious groups. Such legacy presumably depends on the particular historical context, the interacting groups, and the type of outcomes under study. Our study focuses on Greeks and Armenians of the Ottoman Empire who have so far received very little attention in empirical work on minorities. ${ }^{10}$ To the best of our knowledge, our paper is the first systematic attempt to identify the contribution of Greeks and Armenians to local development in Turkey, and to offer evidence about the likely channels.

Some studies look at outcomes in the aftermath of persecutions and expulsions of minority groups to assess the importance of human capital spillovers or to test various economic theories. For example, Waldinger (2012) investigates the effect of the expulsion of Jewish academics on German universities as a negative shock to human capital spillovers in academia. He finds no evidence of peer effects at the local level. Our paper differs in terms of general motivation and the type of spillovers involved. Instead of evaluating the effect of expulsions as a shock, we aim to trace the potential legacy of intergroup spillovers that took place prior to expulsions. Also, unlike Waldinger (2012) who is concerned with scientific output in academia as an outcome, our interest is to measure minority influence on educational attainment and economic development at large. In a recent study, Chaney and Hornbeck (2015) use the expulsion of about 130,000 Moriscos (Spain's converted Muslims) from the Kingdom of Valencia in 1609 as a quasi-natural experiment to study the Malthusian convergence dynamics following this population shock. They find that even two centuries after the expulsions, population was lower and income per capita was higher in former-Morisco areas than in former-Christian areas, suggesting that Malthusian convergence was significantly delayed. In contrast, our study investigates persistence of initial conditions over a period, from late 1920s until 2000s, that cannot be classified as Malthusian, and hence our results cannot be interpreted in the same spirit. Focusing on a more recent period, Acemoglu

\footnotetext{
${ }^{10}$ Grosjean (2011) is an exception.
} 
et al. (2011) provide evidence on how the persecution of Jews by the Nazis in the WWII left a persistent impact on the social fabric and education of Russian cities. They show that cities where the Holocaust was more severe have worse economic and political outcomes than other cities. Again in contrast to these two papers, we are interested neither in assessing the direct effect of the expulsions nor in evaluating the speed of recovery after the historical shocks. Instead, we compare districts with high and low minority presence before the expulsions to estimate the longterm contribution of Armenians and Greeks to contemporary local development. ${ }^{11}$ We argue that, in the short- to medium-run, expulsions possibly had negative repercussions on affected regions. However, centuries-long co-existence may have generated aggregate positive spillovers in minority regions which last even long after the originators are gone. In this sense, our work is more related to Grosfeld et al. (2013) who focus on the Pale of Settlement area where Jews were allowed to live in the Russian Empire, and show that current residents of the Pale of Settlement exhibit higher antimarket attitudes, lower entrepreneurship and higher trust. In contrast to the negative legacy of the forced co-existence of Jewish and Christian groups on the aforementioned outcomes in the Pale of Settlement, we find a positive legacy of unforced co-existence of Greek and Armenian communities with their Muslim neighbors on the level of development. Pertinently, it is important to emphasize the context of the Ottoman millet system which tolerated diversity, allowed minorities to prosper, and thus, paved the way to human capital and technology spillovers from the minorities to the local Muslims through peaceful interaction. In the case of the Jewish communities in Europe, the institutional setup did not always allow such positive interaction and spillovers. Relatedly, Johnson and Koyama (2016) argue that Jewish presence had contributed to urban development in pre-industrial Europe especially in cities with greater religious tolerance towards Jews.

The literature on minorities largely emphasized the role of human capital in development (Glaeser et al., 2004), and, in particular, the role of the human capital possessed by ethno-religious minorities with occupational specialization, higher education and knowhow (Botticini and Eckstein, 2007). In this strand, Becker and Woessmann (2009) provide evidence that Prussian counties with a higher concentration of Protestants were more prosperous in the late 19th century, and they show this effect to be driven by Luther's promotion of education. Hornung (2014) studies the

\footnotetext{
${ }^{11}$ Yet, we believe that our findings are informative, at least qualitatively, about the counterfactual trajectory that Turkish economy might have followed if the expulsions had not happened.
} 
long-term effects of skilled-worker immigration on productivity focusing on Huguenots' migration to Prussia. He identifies the causal effect of Huguenot settlements on the productivity of textile manufactories hundred years after their immigration. Our historical context is different. Unlike Huguenots in Brandenburg-Prussia who settled in the region during the late 17th century and were not subjected to mass removal afterwards, Armenians and Greeks in Anatolia were more indigenous to their locations than the rest of the local populations, yet they were expelled. Since we focus on post-expulsion outcomes, the mechanisms underlying contemporary productivity effects in our setting are likely to be different from those established by Hornung (2014). We contribute to this strand of the literature by providing evidence on the channels of persistence and showing that the legacy of the non-Muslim minorities on current outcomes largely reflects their influence on local human capital accumulation during the long co-existence of the two communities.

Our work is also related to Heldring et al. (2015) who present evidence that the Dissolution of the English monasteries in 1535 and the resulting change in the distribution of landholdings was instrumental in the emergence of the British gentry class and had a long-term effect on the geography of early industrialization in Britain. In our setting, after the expulsions, some of the minority property was looted by local Muslims. Some of the abandoned houses and land was either transferred to new Muslim immigrants or auctioned off to local Muslims at low prices. Anecdotal evidence suggests that politically well-connected local elite and bureaucrats captured a disproportionately higher share from expropriated land, shops and factory buildings that used to belong to minorities (Der Matossian, 2011; Üngör and Polatel, 2011). Thus, the redistribution of minority assets among the Muslims might have contributed to wealth concentration facilitating accumulation of physical capital and spurring development. However, our results suggest that, in our case, this particular channel of persistence is less important than the human capital channel. Also, our setting differs from Heldring et al. (2015). Because expropriations occurred following the mass expulsions of Greeks and Armenians, this might have different implications from that of the dissolution of monasteries, which had no direct effect on the demographic composition of the affected regions.

This paper also speaks more broadly to the literature on the persistent effects of historical events. In this literature, researchers have studied, for example, the economic and institutional consequences of the outbreak of the Black Death in Europe in the 1340s (Postan, 1973; North and 
Paul, 1973; Brenner, 1976; Jedwab et al., 2016), the effects of the 1840s Irish famine on emigration and industrialization (O'Rourke, 1994; Whelan, 1999; O Grada, 2000), the effects of the loss of life and economic damage caused by wars (Davis and Weinstein, 2002; Miguel and Roland, 2011), and the persistent effects of slavery and slave trade on sub-Saharan Africa (Law, 1991; Lovejoy, 2000; Nunn, 2008).

Lastly, this paper contributes to the literature on regional development in Turkey (Altuğ et al., 2008; İçduygu, 2009; Mutlu, 2002; Pamuk, 1987; Toprak, 2012). Previous work by historians on the legacy of the Armenian and Greek populations of Anatolia have a qualitative nature and mostly focus on particular localities. This paper is the first study documenting empirically on a large geographical scale the positive relationship between regional concentration of Ottoman Greeks and Armenians in Anatolia and subsequent Turkish development. ${ }^{12}$

\section{Historical Background}

\subsection{Armenians and Greeks in Anatolia prior to the Ottoman Rule}

\subsubsection{Geography and Culture of Armenian and Greek Ethnicities}

Historic homeland of Armenian people, also called the Armenian Plateau, Armenian Highland or Historic Armenia, is a mountainous region south of the Caucasus Mountain Range (shown with the black dashed lines in Figure S.1a in the Online Appendix). Western half of this historic homeland (also called Western Armenia) coincides with the eastern half of modern Turkey, where an overwhelming majority of the Ottoman Armenians used to live for many centuries.

Hittite and Assyrian sources suggest that already around 14th to 11th centuries BC, Armenian Plateau was home to various proto-states. Armenian tribes and their language came to dominate the region by the middle of the 1st millenium BC. Official chronicles from around 6th century BC refer to the Armenian Plateau as 'Armenia' (Khachikyan, 2010). From the first unified Armenian state of Van Kingdom (860 BC - 590 BC) -the Kingdom of Urartu- to the Armenian Kingdom of Cilicia (1080-1375), a series of Armenian states ruled over the Armenian Highlands and

\footnotetext{
${ }^{12}$ Quantitative studies of Turkish economic development and regional income disparities, such as Mutlu (2002) and Altuğ et al. (2008), have largely ignored the long-term consequences of the expulsions. It is important to recall that this paper does not aim to evaluate the direct impact of the expulsions either, and our findings should not be interpreted as such. Instead, the positive correlations we document between past minority presence and contemporary development should be viewed as evidence on the persistent Armenian and Greek legacy.
} 
its peripheries. Christianity began to penetrate Armenia during the rule of Sanatruk Arshakuni (88-110 AD), and during the Arsacid dynasty the Kingdom of Armenia adopted Christianity as the state religion (in $301 \mathrm{AD}$ ), making Armenia the first Christian state in the world.

Following the adoption of Christianity, first religious schools were established. Historically, Armenian society ascribed an important role to education. ${ }^{13}$ Already by the 10 th century, almost all Armenian cities and many rural population centers had elementary schools that were subsidized by the state and the Church. Many students were sent abroad to continue their studies in prestigious schools of the time. As early as the 9th and 10th centuries, Armenians established institutions of higher education (called Vardapetarans) in large cities and monasteries. Later in the 13th and the 14th centuries, some of these schools transformed into universities and contributed to the growth of science and culture in Armenia (Khachikyan, 2010).

Like Armenians, Greeks have been inhabiting Anatolia for centuries before Turks arrived. But, unlike Armenians, who were largely settled in the Eastern half of Anatolia, Greeks were settled predominantly in central and western Anatolia. Greeks were native to a large territory spanning several regions in the Eastern Mediterranean including the Ionian Sea, the Aegean Sea and the western coast of Asia Minor, Cyprus, Egypt as well as Istanbul, the Balkans, the south western shores of Black Sea and Cappadocia in central Anatolia.

First Greek colonies (city-states) in Asia Minor were established during the 13th century $\mathrm{BC}$, and the ethno-genesis of Greeks is considered to have occurred in the 8th century BC with the development of Pan-Hellenism (Burckhardt, 1998). With the Roman Empire's conquest of Greece, almost all of the world's Greek speakers lived as citizens or subjects of the Roman Empire. While the Western Roman Empire collapsed in 476 AD, the Eastern Roman Empire (Byzantine Empire) survived as the primary home to Greeks until the conquest of Constantinople -the capital of the Empire- by the Ottomans in the 15th century (see also Figure S.1b in the Online Appendix).

Unlike the Western Roman Empire, Byzantine Empire was oriented towards Greek, rather than the Latin, culture. Christianity became official state religion in the late 4th century. After the 7th century, Byzantine Empire became increasingly influenced by Greek culture so much so that Greek became the Empire's official language instead of Latin (Haldon, 1990; Haywood, 2001). By

\footnotetext{
${ }^{13}$ Armenian alphabet was developed around 405 AD by Mesrop Mashtots. First complete Armenian book and one of the first medical books date back to the 9th and the 13th centuries, respectively.
} 
the standards of the time, Byzantine society was highly literate. ${ }^{14}$ Until 12 th century, literacy rates among Byzantine Greek population were higher than in the West. Access to elementary education and book ownership were also widespread (Browning, 1989).

\subsubsection{Penetration of Islam and the Arrival of First Turkic Tribes}

First Arab incursions into the region started in the mid-7th century when the Arab Caliphate captured the Near Eastern provinces of Byzantium. As a result, part of the Armenian population in the region was driven out of fertile lands into the mountainous areas, and Muslim tribes were resettled in these places to form self-governing emirates.

In the 11th century first wave of nomadic Turkic tribes from Central Asia began to penetrate into Asia Minor through eastward expansion of the Great Seljuks - a medieval Turko-Persian, Sunni Muslim empire. Seljuk Turks' victory under the leadership of Alp Arslan against the Byzantine army in the Battle of Manzikert (1071) was a critical juncture for the fate of the region. Following this victory, Alp Arslan authorized numerous Turkmen beys to carve their own principalities out of formerly Byzantine Anatolia, and these beyliks established control of the region as far as the Aegean Sea. This event was important not only because it brought Armenia under Turkish domination but it also ushered in a new era of Islamic dominance against the Christian Orthodoxy in Asia Minor. Nevertheless, Byzantine heritage (or what Vryonis (1971) call the "Byzantine Residue") permeated into the cultural fabric as well as the institutional and socioeconomic structure of Turkish Anatolia in centuries to come.

The dominance of Islam in Anatolia was sealed by the Ottoman conquest of Constantinople in 1453 and the collapse of the Byzantine Empire. Over the next couple of centuries, Islam spread to the Balkan Peninsula all the way to central Hungary via Ottoman conquests. Meanwhile the Armenian homelands in the east were the main scene of a long warfare between Ottomans and Persians from mid-16th to mid-17th century. The wars came to an end with a peace treaty in 1639 which led to a partitioning of Armenia whereby Western Georgia and most of Western Armenia came under the Ottoman rule. In the 17th and the 18th centuries, thanks to a relatively durable

\footnotetext{
${ }^{14}$ According to Oikonomidês and Langdon (1993) Byzantine society around the 13th century had "a completely literate church, an almost completely literate aristocracy, some literate horsemen, rare literate peasants and almost completely illiterate women".
} 
peace between Ottoman Turkey and Iran, agricultural activity in Armenia recovered, and trade (both local and transit trade) and craftsmanship took off.

\subsection{Armenians and Greeks under the Ottoman Rule}

Since its foundation circa 1299 until its dissolution in 1922, the Ottoman Empire stretched across Asia Minor, the Balkans, Maghreb and the Arabic peninsula; and it ruled over ethnically and religiously heterogeneous peoples. Yet, state religion in the Ottoman Empire was Sunni Islam, and from the late 14th century onwards Ottoman sultans held the caliphate title.

While state tolerance against non-Muslims varied by time and place, the Ottoman Empire was fairly tolerant against other religions for most part of its existence. In principle, forced conversion to Islam was against the Sharia law, and non-Muslims were free in their choice of residence and profession with some exceptions. As the Empire expanded and incorporated a greater number of diverse peoples, the need to institutionalize various groups into the empire has emerged. After the conquest of Constantinople, Sultan Mehmet II laid the foundations of the millet (religious community or nation) system. This system played a key role for the stability of the Ottoman order by governing the internal affairs of a multi-religious and poly-ethnic imperial setting. Under this system, non-Muslim subjects of the Ottoman Empire enjoyed a certain degree of autonomy in their internal affairs pertaining to religious and cultural practices, education, fiscal matters and civil law. In particular, each ethnoreligious group was organized into a separate millet with the right to elect its own religious leader and to establish its own courts to oversee legal disputes between members of the same community. ${ }^{15}$

Despite their autonomy in economic and communal affairs, non-Muslim subjects (dhimmis) of the Empire had an inferior status vis-a-vis the Muslims in certain aspects. For example, only Muslim subjects were allowed to testify against Muslims in court. Unlike Muslims, non-Muslims were obliged to pay a poll tax (jizya) in exchange for their status as reayas ('protected flock' of the sultan). This status meant that the state was to ensure their personal safety and the security of their property. Due to the key role non-Muslims played in the Ottoman economy and their contribution to tax revenues, the State-minority relations could be best described as mutual rather than one-sided- dependence.

\footnotetext{
${ }^{15}$ However, all judicial cases involving a Muslim party had to be overseen by the Islamic courts.
} 


\subsubsection{Muslims and non-Muslims in the Economic Sphere}

In the 19th century, the Ottoman Empire was a predominantly agrarian economy with over $80 \%$ of the population living in rural areas. Farming was mostly traditional and took place on small land holdings of peasants. Agricultural production was the main tax base of the Ottoman state. Tax collection was achieved through a system of tax farming (iltiza). The state would auction off the right to collect taxes in a given place and for a certain period, and the winners (tax farmers) would pay the state in advance. Tax farmers would typically finance these purchases through loans from Jewish, Greek or Armenian banks in the big cities.

Like farming, manufacturing was also largely traditional and small-scale. In towns and cities, craftsmen, organized in guilds, dominated manufacturing thanks to monopolies granted by the government in exchange for tax revenues and political support. Population growth in Anatolia was slow at about 1 percent a year (Issawi and Assawi, 1980, pp.11-12). Migration from rural areas to towns and cities was weak, and the share of urban population rose from 17 percent in the 1830s to only 22 percent by 1912 (Issawi and Assawi, 1980, pp.34-35).

Compared to its Muslim subjects, Armenians and Greeks of the Ottoman Empire were, on average, at a relatively more advanced stage in their economic modernization. However, a number of studies on financial markets suggest that the gap was not so significant before the 18th century, and the Greek and Armenian economic ascent began in the late 18th century. For example, records from 16th century Turkey indicate that while Christians had significant control in some sectors of trade and commerce, Muslims were dominant in others (Lapidus, 1967; Inalcik, 1960). Also, until this period, minorities did not dominate financial markets, and cash waqfs (primitive non-intermediating credit suppliers) were largely controlled by Muslims.

However, by the 19th century, non-Muslim minorities of the Empire -especially Greeks and Armenians and to a lesser extent Jews- had a disproportionate control over trade, commerce and finance (Kuran, 2004a). They were engaged in higher value-added sectors in trade, agriculture and manufacturing, and owned greater wealth relative to their Muslim counterparts (Kuran, 2004a; Der Matossian, 2007; Kévorkian, 2011). For example, Armenian merchants dominated regional overland and caravan trade with Iran and India (Eldem, 2006). In the Black Sea region, Armenian and Greek merchants dominated the brokerage between Western and local traders as well as the 
procurement and the distribution of goods. For instance, by the end of the 19th century, in the province of Trabzon, out of 33 exporters, three were Turks, one was Swiss, and the remaining 29 were Greek or Armenian, while out of 63 major importers only 10 were Turkish (Kuran, 2004a). ${ }^{16}$ Along the Aegean coast, Greeks dominated commerce. ${ }^{17}$ Greeks constituted 40 to 60 percent of the merchants, although they formed 20 to 38 percent of the regional population (Kuran, 2004a). Similarly, in Istanbul, a predominantly Turkish city, Turks made up just 4 percent of export-import merchants by the time of the First World War. Official statistics also confirm these numbers. According to the Ottoman yearbook of 1912, Muslims of the empire, 81 percent of the total population, not only had no role in trade with Europe, but also had only a limited role in local trade. They made up 15 percent of local traders, while Armenians and Greeks made up 23 and 43 percent of local traders, respectively (Sonyel, 1993). A survivor's report after the WWI suggests that even in Erzurum, which today is a poor eastern province in Anatolia, Armenians were dominant in the economic realm. ${ }^{18}$

In the middle of the 19th century in the Ottoman Empire, the westernization of trade and economic links provided great impetus for trade and industry, spurring development of production within the country. However, not all regions of the Ottoman Anatolia benefited from these improvements equally. Secondary literature on minorities in the Ottoman period is full of anecdotal evidence that regions with historically high Armenian and Greek presence enjoyed considerable advantage. For example, the city of Maras, one of the north-eastern gates to the old Armenian Kingdom of Cilicia, thrived in the 19th century mostly owing to the presence of Armenian mastercraftsmen and merchants despite its relative isolation from main trading routes as well as other unfavorable conditions such as the failure of the government to provide enough protection for traders against bandit groups, and the taxes and duties merchants had to pay (Keshishian, 2011). Armenians of Maras played an important role in the formation of the region's economic relations.

\footnotetext{
${ }^{16}$ At the time, Greeks and Armenians made up 40 percent of Trabzon's population (Turgay, 1982).

${ }^{17}$ A large majority of Ottoman traders and shippers were Greeks from the Aegean coast and islands. Their growing commercial interests since the late 18th century led them to create an international network in major trading centres outside the empire, such as Marseilles, Trieste and the recently founded Russian port city of Odessa on the Black Sea.

${ }^{18}$ According to this report, 80 percent of local commerce in the Vilayet of Erzurum was due to Armenians. They owned about 60 commercial firms with an annual turnover of more than 30,000 Turkish pounds, 500 firms with a turnover between 10,000 and 15,000 Turkish pounds and 2,500 firms with a turnover between 800 and 1,000 Turkish pounds. They controlled most of the trade with other provinces and almost all foreign trade of the vilayet (Kévorkian, 2011).
} 
Production and commerce in the villages were almost fully controlled by Armenians, and the newly-created financial upper class in the city consisted exclusively of Armenians. ${ }^{19}$ The members of this financial upper class developed contacts with progressive towns, quickly adopted the latest European customs and manners and introduced them into Maras. They also imported the latest trading methods into their home towns. Being aware of the importance of education as a key for success in modern economic sectors, they not only directed their own children towards education, but they also laid the ground for educational work in Maras by founding schools.

Beyond anecdotal evidence, descriptive evidence, on the role of minorities in the Ottoman economic structure as of $1894 / 1895,{ }^{20}$ suggests that the average employment share in commerce and industry in provinces with above median minority presence was $33.7 \%$, while it was $30.3 \%$ in provinces with below median minority share. ${ }^{21}$ Moreover, average income per capita among the Ottoman provinces with above median minority share was larger than that of those provinces with below median minority share, 123.6 kurus versus 111.5 kurus. While this gap may seem small, given that the Ottoman economy was largely Malthusian at the time, the difference in income per capita clearly understates the actual productivity gap. In contrast, population density is a more relevant proxy for productivity. Figure 1 describes the evolution of average population density in provinces with above and below median minority shares between 1893-1906. Figure 1a shows that the population density in places with above median minority share was almost twice as high in 1893 as those with below median minority share. Importantly, this gap grew even larger by 1906 . High minority provinces not only had larger population density at the end of the 19th century, but they also experienced faster growth on average compared to those provinces with low minority presence. Figure $1 \mathrm{~b}$ provides further evidence on the positive and statistically significant association -conditional on year fixed effects- between population density and minority share between 18931906 at the level of Ottoman provinces.

Why did minorities enjoy greater economic success? Various explanations have been suggested by scholars. One reason is that Muslims eschewed finance and commerce, and avoided

\footnotetext{
${ }^{19}$ In contrast to Armenians, very few of the local Islamic upper class were merchants or artisans. Most of them were either landowners or government officials. The villagers, on the other hand, were mostly employed in farming and sheep farming.

${ }^{20}$ Based on information for 27 Ottoman provinces reported by Karpat (1985).

${ }^{21}$ For example, in Istanbul in 1885, Greek and Armenian population shares were 22 and 20 percent, respectively, while their shares in employment in commerce and industry were 36 and 43 percent, respectively (Karpat, 1985).
} 


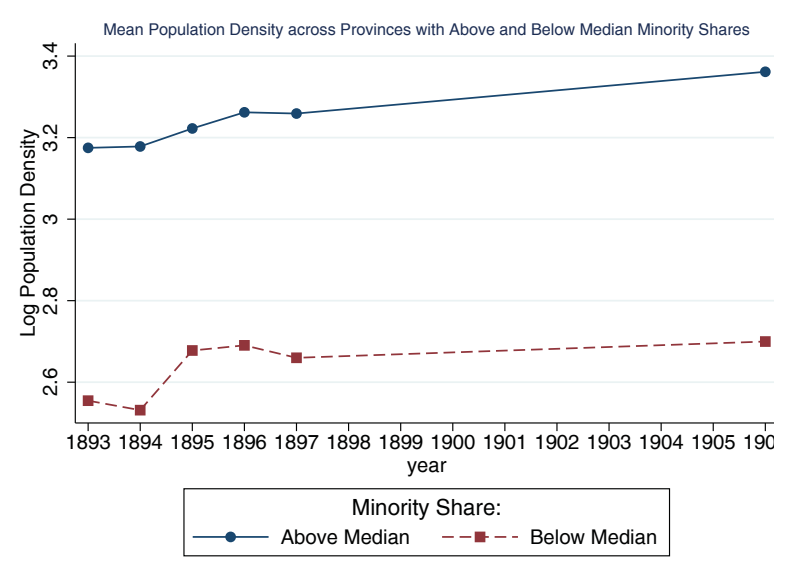

(A)

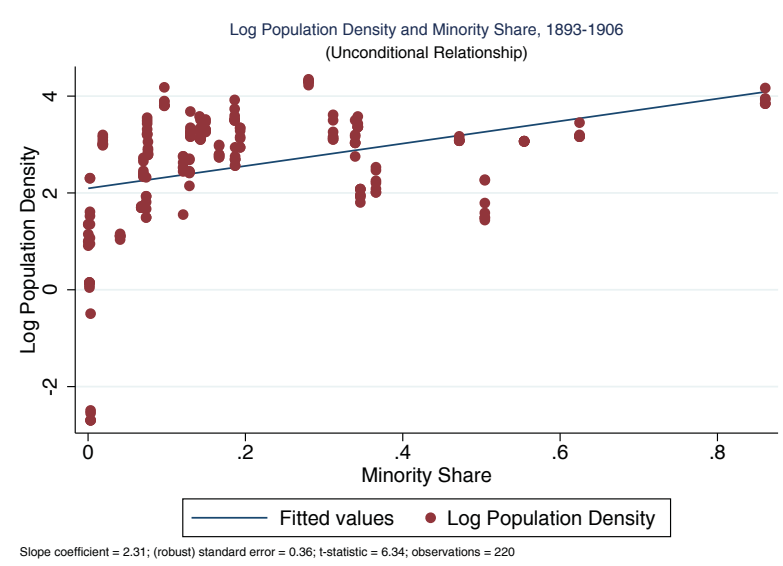

(B)

Figure 1: Minority Presence and Population Density in Ottoman Provinces

interest whereas Christians were not subjected to the prohibition of interest lending. Another common explanation is that Westerners favored the Christian subjects of the Ottoman Empire, and in turn, these business networks with the Westerners proved increasingly lucrative as modern capitalism gained pace. Kuran (2004a), on the other hand, argues that legal pluralism within the Ottoman Empire allowed minorities to choose more modern Western legal institutions. Thus, minorities thrived economically by adopting Western business practices, forming economic alliances, settling disputes in Western courts, and benefiting from tax concessions offered to non-Muslims under Western protection, whereas Muslims could not benefit from such modern institutions. ${ }^{22}$ Moreover, Islamic inheritance law was more egalitarian than its Western counterparts, which limited wealth concentration for Muslims and stifled capital accumulation. ${ }^{23}$ Moreover, the fact that Islamic courts were openly biased in favor of Muslims ironically implied that Muslims on average were less trustworthy as borrowers and faced higher borrowing costs due to the additional risk faced by lenders (Kuran and Rubin, 2016). Another potential factor is that non-Muslim males were effectively exempt from military service. In contrast, a male Muslim would potentially face some sort of military duty for as much as twenty-four years (Karpat, 1985). The fact that occupational specialization patterns of Armenians and Greeks were markedly different from those of Muslims

\footnotetext{
${ }^{22}$ In the 18th and especially over the 19th centuries, a greater number of local Christians sought to acquire decrees of appointment (berat) to benefit from the privileges that capitulations (political and economic concessions granted by the sultan) offered to the Christian foreigners (Zurcher, 2004, p.11).

${ }^{23}$ See Kuran and Lustig (2012) and Kuran (2012) for a detailed discussion of the Islamic legal tradition and its implications for minorities.
} 
certainly played a role in the economic divide between these communities. These distinct patterns also contributed to and were possibly reinforced by the differences in educational attainment, as suggested by Botticini and Eckstein $(2005,2007)$ for the case of Jewish minorities.

Due to scarce data, it is not possible to make a reliable comparison between the education levels of Muslims and non-Muslims of the Ottoman Empire. Yet, it is safe to conclude that the relative educational attainment of Muslims fell over the centuries possibly owing to the rigidity of waqf-based Muslim educational institutions (Kuran, 2004b). Based on data from Ottoman provinces in 1894/95, the average proportion of primary school students within non-Muslim population of Greeks and Armenians combined was about 1.6 times as high as the proportion of primary school students within the Muslim community (Figure 2).

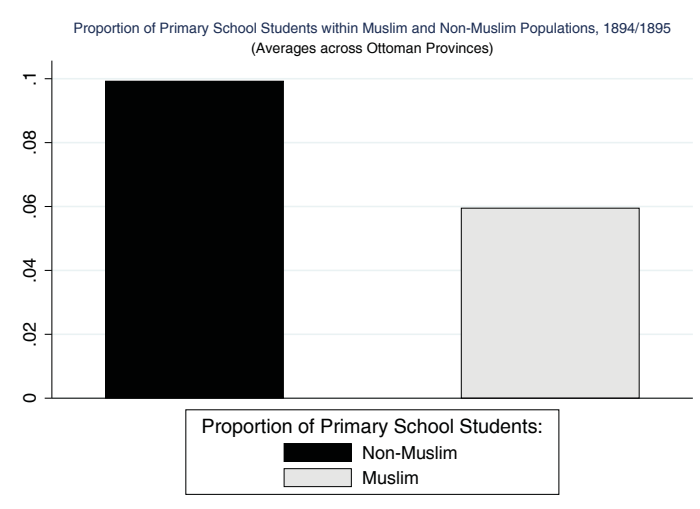

Figure 2: Average Minority-Muslim Education Gap in Ottoman Provinces, 1894/1895

\subsubsection{Intercommunal Relations and the Scope for Human Capital Spillovers}

The history of co-existence of Muslim and non-Muslim communities in what is today modern Turkey is fairly long (circa eight centuries). Presumably, this is a long enough period for inter-communal exchange between Muslim and non-Muslim groups with an impact on the long-term cultural and economic evolution of different regions of Anatolia. In particular, intergroup differences in skill levels and occupational specialization imply that diffusion of technical knowledge and cultural traits possessed by Armenian and Greek communities to their Muslim neighbors may have consequences for local development. Partnerships with non-Muslim businessmen, apprenticeship with Armenian and Greek master-craftsmen or simply proximity to economically successful minorities might have 
worked as important channels for skill acquisition and diffusion of tacit knowledge among local Muslims, and thus, fostered local development even after minorities were expelled. ${ }^{24}$

While we have data about ethno-religious composition of different regions, we do not have systematic information about the strength of inter-communal relations at the regional level. Although millet system implied institutional distinctions between different ethnoreligious communities, social segregation between them was less strict than implied by earlier research on Ottoman society (Benjamin and Bernard, 1982). While it is natural that due to cultural reasons these groups were to some degree clannish in their social interactions, anecdotal evidence from the late Ottoman period suggests that Muslims and non-Muslim elements regularly interacted in the economic sphere. ${ }^{25}$ Although some guilds were divided along religious and regional lines (e.g. bankers, butchers, porters), many of them were religiously mixed. In the rural areas of the Eastern provinces, there were villages that were entirely Armenian or Muslim, but also villages of mixed populations. In urban centers, Christians lived side by side with their Muslim neighbors (Kévorkian, 2011). Yet, intercommunal economic ties were presumably stronger in major economic centers, and bigger cities and towns. ${ }^{26}$

\subsection{Expulsions and the Process of Ethno-religious Homogenization}

In the second half of the 19th century, it was evident to the ruling elite that the previous modernization and centralization attempts to reverse the decline of the Ottoman Empire were largely ineffective. While nationalism movements in the Balkans were gaining impetus, European powers were increasing their pressure on the Empire to improve the conditions of Christian minorities and grant them equal rights as its Muslim subjects. Right after Abdulhamid II acceded to the Ottoman throne, another setback, the defeat in the Russo-Ottoman War of 1877-78, came as a

\footnotetext{
${ }^{24}$ For example, at the turn of the 20th century, in most of the eastern provinces of the Ottoman Empire, Armenians had unchallenged control of crafts guilds. Moreover, Armenian craftsmen from different regions specialized in a wide array of crafts. For instance, Van's tailors, goldsmiths and tinsmiths were well known; Kayseri's architects, carpenters and masons had an excellent reputation; in Sivas Armenian blacksmiths and weavers would stand out; in Amasya and Malatya textiles were the main specialization (Kévorkian, 2011).

${ }^{25}$ For example, according to the testimonial evidence from Houshamadyan Project about social life in the town of Palu in the Vilayet of Diyarbekir, the primary place that brought Kurds, Armenians and Turks together to create social links was the town market: "All the grown men, due to their trade or business, have links to it [the town market]. Young boys often help their fathers or, outside school hours, are apprentices with one or other skilled artisan. It is certain that this continuous link with the market and the dynamism are the reasons for the Palu male Armenian to master spoken Turkish and Kurdish (with its various dialects)."

${ }^{26}$ Gerber (1988) points out that guilds were more religiously mixed in Bursa (a big city) than in other towns.
} 
major blow. It led to the reestablishment of the Bulgarian state and de jure independence of Romania and Serbia-Montenegro from the Ottoman Empire, costing the Empire further territorial losses. Following the war, the Ottoman Empire and the Western powers -including the United Kingdom, Austria-Hungary and Russia- signed the Treaty of Berlin which amended the post-war treaty of San-Stefano between Russians and Ottomans. The treaty brought concerns about the state's treatment of Ottoman Armenians and their future in the Empire -the Armenian Questiononto the international stage.

The human suffering and the humiliation during the Balkan Wars (1912-1913) and the WWI inevitably contributed to the common perception among the Muslim population that Christian minorities were disloyal and deceitful foreign elements, and almost domestic foes. Similarly, nonMuslims, increasingly disillusioned about the state's intention to grant them equal rights and its commitment to ensure their security, were losing their hope for peaceful co-existence under the Ottoman rule. National aspirations of independence were gaining support. While a multicultural, multiethnic empire was falling apart, each of its constituent groups, including the Armenian and the Greek communities and the Turkish Muslims, was compelled to focus on their own future.

\subsubsection{Expulsion of Ottoman Armenians}

As the hopes for empire's territorial integrity and peaceful co-existence substantially diminished, for the Christian communities in the European part of the empire it was simply a matter of time that they divorced themselves from Istanbul. The fate of Armenians, on the other hand, was more intricately linked to the fate of the Ottoman state, because their homelands were in the Asiatic part of the empire where Muslim Turks, Kurds and Arabs -depending on the region- outnumbered Christians.

The Berlin Treaty failed to provide a viable and enforceable solution to the Armenian Question. The increasing nationalistic sentiments among Armenians, the demands and lobbying efforts of Armenian Committees at the international arena further fueled the government's distrust for Armenian elements. Meanwhile, armed resistance by local Armenian self-defense forces against the abuses of local officials and Kurdish begs (Kurdish chieftains) intensified Abdulhamid's fears of large scale uprisings and territorial losses in the Eastern provinces. He subsequently sided with Kurdish begs and formed armed regiments of Kurdish militia (called Hamidiye regiments) who 
carried out a series of local massacres in the east during 1894-96 against the Armenians and the Assyrians.

Concerns about the fate of the empire and discontent about Abdulhamid's rule -especially his abolition of the Constitution- were growing among various ranks of a predominantly Muslim and Turkish civilian and military bureaucracy. Eventually, a strong opposition group, unified under the Young Turk Committee of Union and Progress (CUP), staged a coup in 1908 and seized power from the Sultan Abdulhamid II. Although CUP's initial reform-oriented agenda was to reinstitute a constitutional and parliamentary framework and to unify all millets under an overarching Ottoman identity, it eventually set on a national homogenization path in the heat of the ongoing external and internal tensions. Traumatized by the loss of the European provinces, Ottomanism ideal was quickly abandoned. Instead, dominant view within CUP singled out Turkish ethnicity as the founding element of the state and promoted Turkish nationalism as the only idea around which territorial integrity can be sustained. The creation of a homeland with a Muslim majority became a political priority for the ruling elite (Zürcher, 2003).

With the outbreak of the First World War, the Young Turk government consolidated dictatorial powers. Ottoman Army was fighting Russians in the Caucasus Campaign. Using their alleged concerns about Armenian support to Russian troops and popular armed resistance as a justification, CUP leaders passed an urgent "Deportation Law" to start the expulsion of Armenians in the Eastern Provinces. Following this law, in April 1915, CUP embarked on a wholesale antiArmenian extermination policy. First, Armenian elite, religious leaders and intellectuals were arrested. Then, Armenian populations of Anatolia and European Turkey were removed through massacres and death marches to the camps in the Syrian desert (Akçam, 2012; Dündar, 2008). By the end of First World War, which also marked the end of the reign of CUP, almost all of more than one million Armenians were removed from Asia Minor; most of them were killed, and those who were able to escape the massacres and survived the deportations took refuge in neighboring countries or migrated to Europe and the US.

\subsubsection{Expulsion of Ottoman Greeks}

Although Greek minorities of the Ottoman Empire also suffered from harassment, expulsion and massacres during CUP's reign, it was not until 1923 that they were expelled from Asia Minor en 
masse. However, the first wave of involuntary mass emigration of Greeks took place towards the end of the Turkish War of Independence in 1922. As the Greek army retreated, many Greeks from Western Asia Minor fled to the Greek mainland (Zürcher, 2003). The second wave of Greek emigration took place in the aftermath of the war as part of the 1923 Convention Concerning the Exchange of Greek and Turkish population. Greece and the newly established Turkish Republic signed a peace agreement in Lausanne, which stipulated an exchange of the Muslim population in Greece for the Orthodox Greek population in Turkey. This involved around 190,000 Greeks, mostly the Central Anatolian and the Pontic Greeks. In sum, the involuntary mass migrations involved around 1.3 million Anatolian Greek Orthodox who were expelled from Anatolia and moved to Greece, and 354,000 predominantly Turkish Muslims who were expelled from Greece and resettled in Turkey (Hirschon, 2003).

In a matter of years, the population exchange program had achieved its goal of religious homogenization on both sides of the Aegean Sea. Both the Orthodox Christian Greek community of Turkey and the Muslims of the Greek mainland were uprooted from their homelands and diminished to irrelevantly minuscule numbers in their original locations (Friedman, 2006). ${ }^{27}$

All in all, in the period starting with the First World War and in its aftermath, deChristianization of Asia Minor dramatically altered the demographics of Turkey and stripped it from virtually all of its Armenian and Greek communities. In the 1893 census, Armenian and Greek shares in the total population were about 8 and 10 percent, respectively, excluding Istanbul. However, by 1927, more than 99 percent of Turkey - excluding Istanbul- registered Muslim.

\section{Data and Empirical Methodology}

\subsection{Data}

\subsubsection{Data on Historical Armenian and Greek Populations}

For historical distribution of Armenian and Greek minorities across Anatolia, we use the population figures reported in the Ottoman General Census of 1881/82-1893 (1893 Census henceforth) (Karpat,

\footnotetext{
${ }^{27}$ That the cross-Aegean population exchange was accomplished so quickly owes largely to the fact that it suited both the young leaders of the emerging Turkish Republic and the interests of Venizelos and other Greek leaders. Both parties did not want to run a country with a large religious minority.
} 
1985). ${ }^{28}$ This census is the first Ottoman Census where not only male, but also female population of the Empire was counted. ${ }^{29}$ Unlike the Muslim groups, who are lumped into one big category, the census classifies the non-Muslim population into various groups by nationality, ethnicity or religion, including Greeks, Armenians, Jews, Bulgarians and other small minority groups. The population figures are reported at the level of kaza (district), which is the third level administrative division after vilayet (province) and sancak (akin to county). Since we focus on the legacy of Armenian and Greek minorities on modern Turkish development, we leave out those Ottoman regions that are outside the contemporary boundaries of the Turkish Republic. Also, there are a few areas within the modern Turkish boundaries (Erzurum, Bitlis, Elaziz and Van), where the census counts were known to be incomplete mostly due to the practical difficulty of counting various nomadic tribes. Although the Ottoman statistical office reported the names of the specific vilayets, sancaks, and tribes for which counts were incomplete and provide population estimates for these areas, these estimates are unlikely to be reliable and they are not available at the district level. Rather than using highly inaccurate estimates for uncounted people and making arbitrary assumptions about how they were distributed across Ottoman districts within a given sancak/vilayet, we drop all modern districts that were mapped to Ottoman locations with incomplete Census counts. Since historical population data for areas that were under Russian occupation at the time of the census counts were not available, the Turkish provinces and districts that fall within these occupied territories are also excluded from the sample.

\footnotetext{
${ }^{28}$ Karpat (1985) argues that the official Ottoman Census records should be deemed as the most reliable source of information about the Ottoman population. One reason is that these censuses were primarily designed to meet administrative and military needs, especially the need to acquire accurate information about the number and the age of the male population for the purposes of recruitment into a modern army. Karpat discusses in length some of the discrepancies and potential biases in alternative sources of information. While it might be too bold to claim that the official censuses of the late Ottoman period present a completely unbiased picture of the non-Muslim presence in the Empire, there is no apparent reason to suspect that any bias in population figures for the minorities varied by region in a systematic way. The 1913-1915 population figures released by the Armenian Patriarchate put the total number of Armenians in the empire to well above the official Ottoman figures; the reliability of these figures were also questioned. Even if these figures were closer to the true numbers, they suffer from the same problems that make the 1914 Ottoman statistics unsuitable (see Data Appendix for a more detailed discussion). More importantly, the statistics of the Patriarchate are confined to the Armenian community, and hence, they do not provide any information on the population of Muslims and other non-Muslim minorities.

${ }^{29}$ The Ottoman censuses were far from perfect. In some vilayets there was serious undercounting of women and children. In some regions, females were even totally excluded from the census count. Mutlu (2003) applies some corrections to the Census figures using Model Life Tables and reports the resulting lower- and upper-bound estimates. However, these estimates are only available at the level of Ottoman vilayets, making them less useful for a disaggregated analysis. Since these regions (Bagdat, Basra, and Musul Provinces, and Ipek and Prizren Sancaks) remain outside the modern Turkish boundaries, missing female figures do not pose a problem for our analysis.
} 
Mapping Ottoman kazas listed in the 1893 Census into modern Turkish administrative divisions is a challenging task. Although historical maps showing the borders of vilayets and sancaks are available, information about geographic boundaries for kazas is absent. This makes it impossible to employ spatial mapping techniques. Instead, we match Ottoman kazas with Turkish districts by name, based on the Ottoman location names listed in Sezen (2006). This source documents how the administrative status and classification of each location evolved from the early Ottoman period until we reach the current administrative units of the Turkish Republic. This information allows us to search for the name of modern districts (ilçe) and identify which Ottoman kaza they used to belong to when the 1893 Census was conducted. ${ }^{30}$ In most of the cases, an Ottoman kaza is either matched with a single district or with multiple modern districts, as the former is usually geographically larger than the latter. ${ }^{31}$ Our unit of observation is a modern district.

Figure 3 presents the geographical distribution of the Armenian and Greek populations in Ottoman Turkey as projected on the modern geography of Turkish administrative boundaries. The population shares reported for each modern district on the map reflect the historical shares of Armenians and Greeks in the Ottoman kaza to which the modern district was assigned.

The maps document the cross-district and cross-regional variation in minority shares and demonstrate the distinct patterns of settlement of the two groups. Armenians were heavily concentrated in their historic homelands in the eastern half of Anatolia, also called as the Western Armenia. Greeks, on the other hand, were more concentrated in the coastal regions in the west, the Thrace region in the northwestern end of Turkey and eastern part of the Black Sea coast.

\footnotetext{
${ }^{30}$ For some modern districts, especially those that are established during the Turkish Republic in areas where there was no settlement during the Ottoman period, it was not possible to identify the kaza or sancak that contains these areas. For these districts, we relied on other sources (mainly web sites of the local state administrations and municipalities) offering information about the history of the district, including where in the Ottoman administrative hierarchy it used to belong. A couple of cases for which no reliable information can be obtained are left out of the sample.

${ }^{31}$ After the one-way mapping process of modern districts onto Ottoman kazas is complete, there were a few remaining kazas that were not assigned to any modern district. Searching through the Ottoman location names database in Sezen (2006), we were able to identify which modern district they overlapped with or contained by. These exceptional cases involve a large modern district whose territory coincides with -or contain- multiple kazas.
} 


\section{Share of Armenian Population (1893 Ottoman Census)}

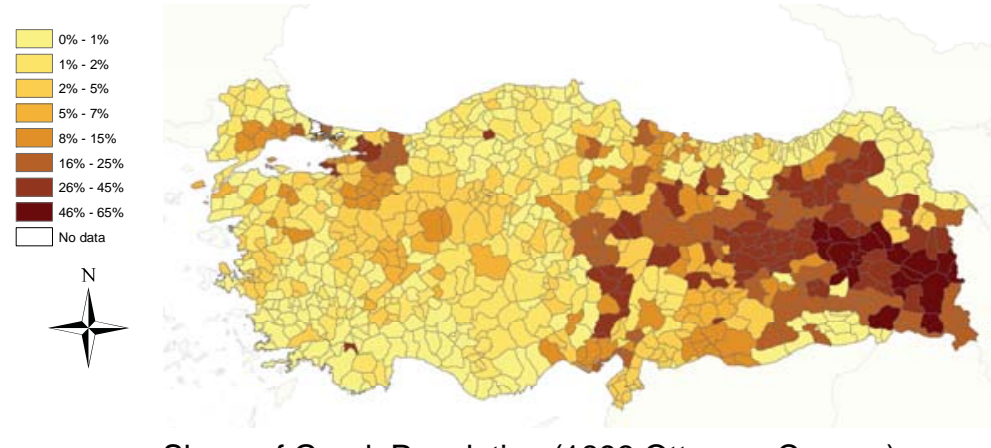

Share of Greek Population (1893 Ottoman Census)

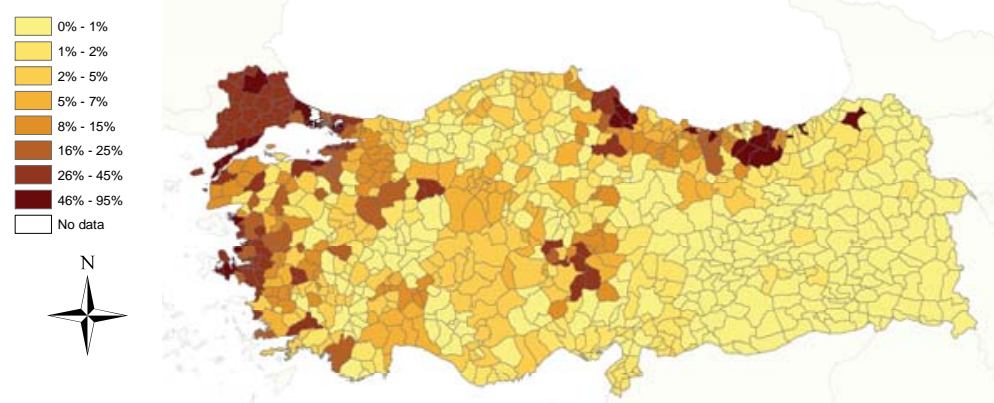

FiguRE 3: Minority Shares in the late 19th century Ottoman Empire

\subsubsection{Data on Outcome Measures}

4.1.2.1 Turkish Population Censuses The first set of long-run outcome measures are the population density and the urbanization rates at the district level from the Turkish census of $2000 .{ }^{32}$ The 2000 Census allows us to investigate the persistent traces of the centuries long presence of Greek and Armenian populations in the Anatolian land, long after the short- and medium-run effects of the radical demographic shifts and adjustments of the early 20th century must have subsided.

In all regressions, we omit from the sample the Istanbul province, the capital of the Ottoman Empire since 1453 and by far the most populous province in modern Turkey. The first reason is that Istanbul is by far the most important historic center of economic activity and home to much

\footnotetext{
${ }^{32}$ Urbanization rate is the share of district population living within the municipal boundaries that define the district centers.
} 
larger Greek and Armenian communities than what would be representative of the other regions of the Ottoman Empire. While the role of minorities in the development of these major hubs of economic activity cannot be ignored, the socioeconomic disparity between Istanbul and the rest of Turkey makes the former highly influential in our empirical analysis. ${ }^{33}$ The second reason is that the residents of Istanbul were exempt from the population exchange between Greece and Turkey as well as the deportation of Armenians.

4.1.2.2 Satellite Light Density at Night The subnational nature of our empirical study requires detailed spatial data on economic development. Existing measures of regional income for Turkey is only available at the province level. In contrast, using satellite light density at night (or luminosity) as a proxy for local economic activity, we are able to exploit variation across more than 700 districts. ${ }^{34}$ The luminosity data are obtained from the Defense Meteorological Satellite Program's (DMSP) Operational Linescan System which reports images of the earth at night captured from 20:30 to 22:00 local time. The satellites detect lights from human settlements, fires, gas flares, lightning, and the aurora. Light density measure is a six-bit number (ranging from 0 to 63) calculated for every 30-second area (approximately 1 square kilometer). Overlaying all images captured during a calendar year, dropping images where lights are shrouded by cloud or overpowered by the aurora or solar glare (near the poles), and removing ephemeral lights like fires and lightning, an annual composite image of time-stable lights are created. ${ }^{35}$ We construct a measure of average light density in 2000 at the district level, averaging across pixels that fall within district boundaries. Two maps in Figure 4 depict the resulting cross-district distribution of average luminosity along with the historical representation of Armenians and Greeks in the Ottoman population.

\footnotetext{
${ }^{33}$ Not surprisingly, including districts of Istanbul in the sample results in a noticeably larger positive correlation between historical minority presence and the indicators of development that we focus on. Therefore, by leaving Istanbul out of the sample, we stack the cards against finding a positive relationship.

${ }^{34}$ The use of satellite light density as a proxy of economic development builds upon previous studies, of which some prominent examples are Henderson et al. (2012), Michalopoulos and Papaioannou (2013), Elvidge et al. (1997), Doll et al. (2006) and Pinkovskiy (2013). These studies document a strong within-country correlation between luminosity and GDP levels and growth rates.

${ }^{35}$ Luminosity data are subject to saturation and blooming. Saturation occurs at a level of light density that is observed in rich urban centers. The corresponding pixels are top-coded with the maximum value of 63 assigned to each of them. Blooming occurs when the light intensity in some areas are perceived by satellites to be stronger than they actually are. This problem is more common for light sources near water and snowy areas.
} 


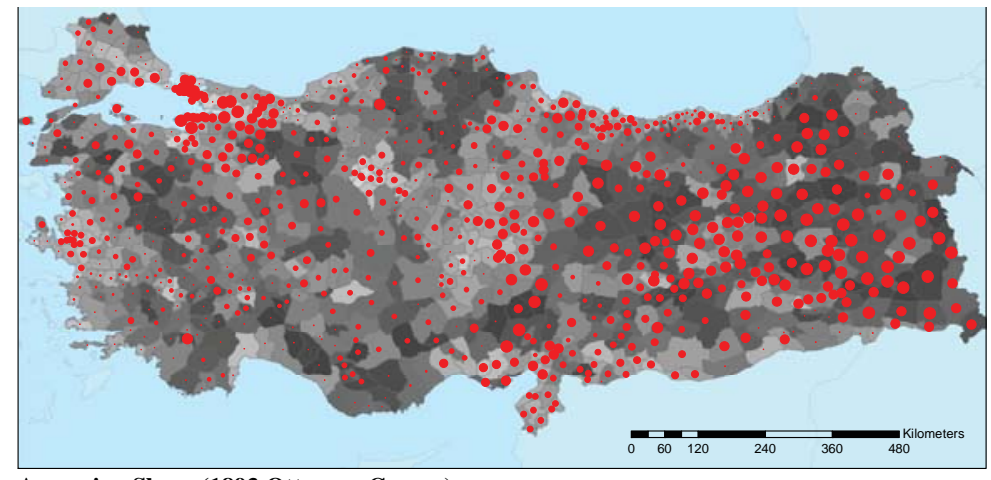

Armenian Share (1893 Ottoman Census)
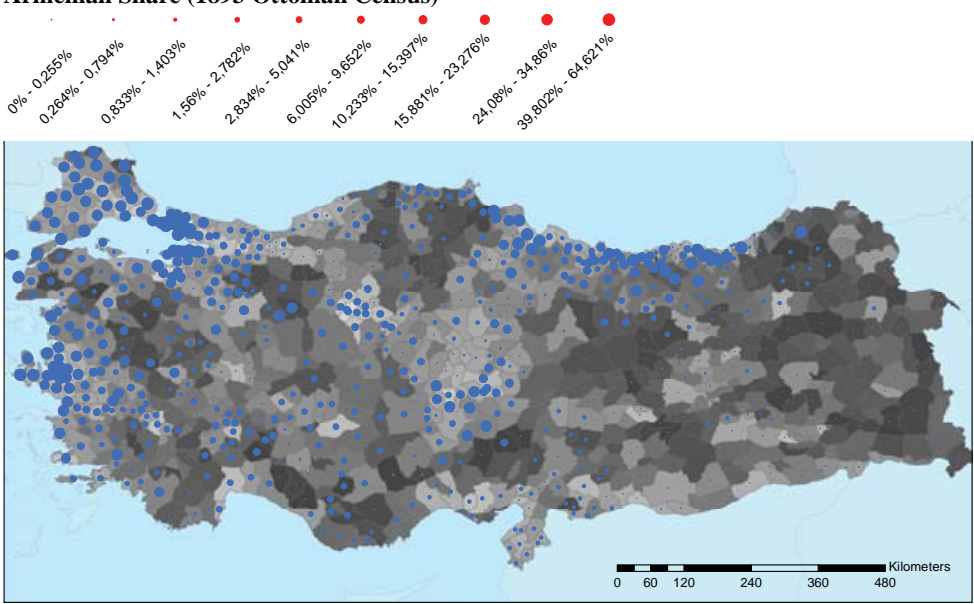

Greek Share (1893 Ottoman Census)

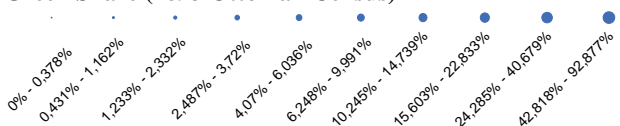

FiguRE 4: Minority presence (1893) and average luminosity (2000) across Turkish districts

Darker areas show districts with lower economic activity as proxied by average luminosity. It is worthwhile to note that these maps simply describe unconditional patterns in the data. Thus, given the potential role geographical and historical factors might have played in shaping the level of economic activity as well as historical minority shares, these maps do not allow us to make a meaningful inference about the potential legacy of Greeks and Armenians on the distribution of contemporary economic activity.

Finally, we make an internal assessment of the luminosity measure. Figure 5 shows a strong positive correlation at the province level between GDP per capita and average luminosity in 2000, 
offering direct evidence that light density is a good proxy for local economic activity in the Turkish context. The R-squared of this bivariate relationship is around 33 percent.

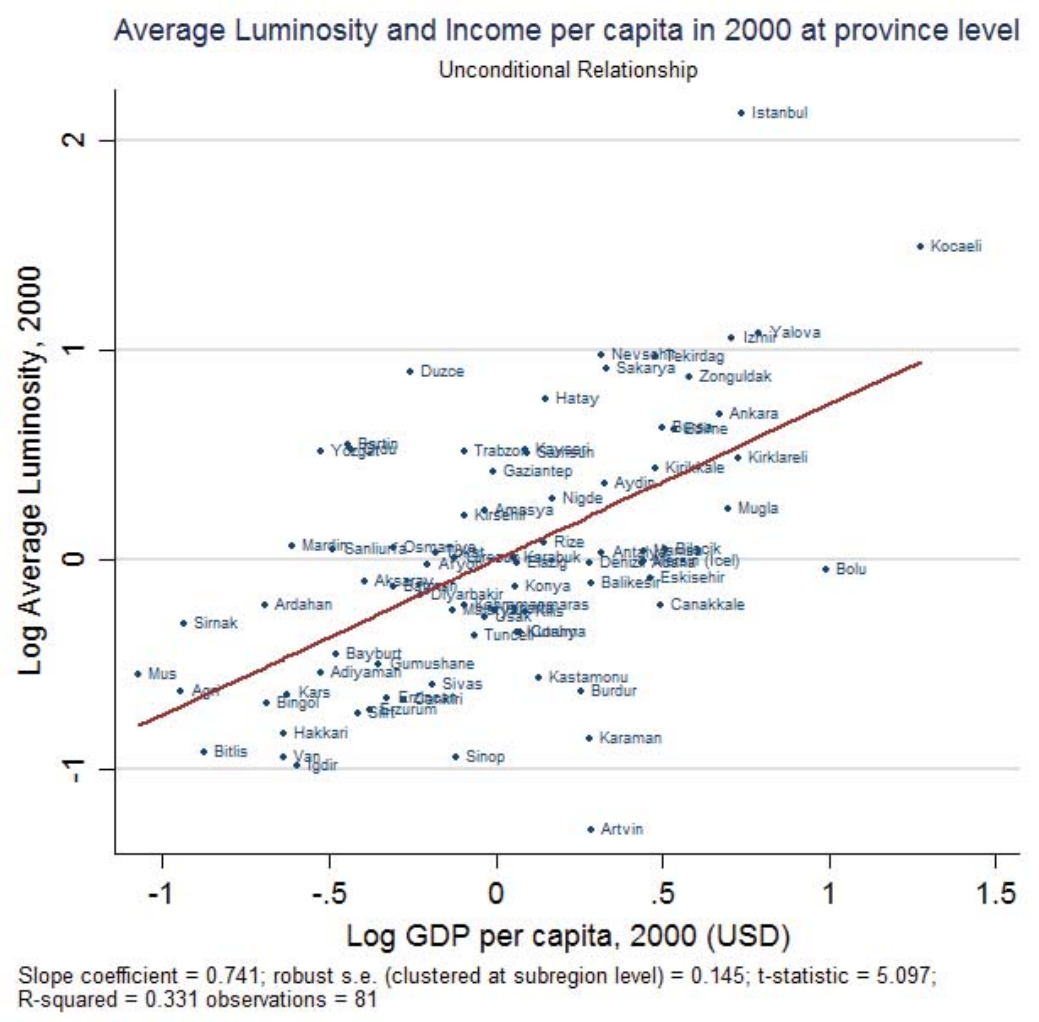

FiguRE 5: The relationship between province income and luminosity

\subsubsection{Data on Control Variables}

To account for potential exogenous factors that might have driven early Armenian and Greek settlement in economically more viable regions of Anatolia, we employ several geographical attributes as control variables. Using the ArcGIS software for spatial data analysis and digital maps, we construct several measures that might drive regional development. These control variables include latitude, longitude, and various other geographical attributes; namely adjacency to sea, lakes, major rivers, average elevation, standard deviation of elevation, average annual temperature and precipitation as well as a measure of agricultural suitability. In all regressions, we also control for population density in $1927 .^{36}$

\footnotetext{
${ }^{36}$ Results are similar when we control for a proxy of population density in 1893 in the Ottoman kaza or sancak. Given that information about boundaries and areas of Ottoman kazas/sancaks in 1893 is not available, population
} 
Table 1 shows the summary statistics for all the variables we use in our empirical analysis including those that will be discussed in subsequent sections. When we present our estimation results, marginal effects reported at the bottom of the regression tables are based on a hypothetical move from the 10th to the 90th percentile of the regional distribution of Greek and Armenian presence. According to the descriptive statistics in Table 1, this move roughly corresponds to increasing Armenian and Greek shares from 0 to 20 and to 26 percents, respectively. ${ }^{37}$

\subsection{Empirical Framework}

Our goal is to assess the relationship between the historical presence of Armenian and Greeks on the one hand and the contemporary outcomes on the other. Key to our identification is the fact that the deportation of Armenians in 1915-1916 and the Greek-Turkish population exchange of 1923 forced virtually all of the Armenian and Greek people of Anatolia to leave their centuries-long homelands over a very short time period. Given this fact, we use the share of Armenians and Greeks in the population prior to these dramatic events as a proxy for the long-term exposure of each district to minority presence.

In our main regressions, we estimate the following baseline specification

$$
y_{i}=\alpha\left(A_{1893}\right)_{k_{i}}+\gamma\left(G_{1893}\right)_{k_{i}}+\delta \ln \left(P D_{1927}\right)_{i}+\theta^{\prime} \mathbf{X}_{\mathbf{i}}+R_{i}+\varepsilon_{i}
$$

where $y_{i}$ is the modern outcome of interest (e.g. population density, urbanization or light density in 2000) for a modern district $i$. Variables of interest are the historical Armenian share, $A_{1893}$, and Greek share, $G_{1893}$, in the Ottoman kaza (or sancak) $k_{i}$ to which district $i$ was assigned. ${ }^{38}$ Including both Armenian and Greek shares simultaneously allows us to account for any bias that

density of an Ottoman location can be approximated by using the sum of the areas of modern districts to which this Ottoman location has been assigned.

${ }^{37}$ Sample averages for Greek and Armenian shares are somewhat different from the overall shares of these groups in 1893 population for two reasons. First, our baseline sample excludes Istanbul and those provinces where census counts were incomplete. Second, since some modern districts are mapped to the same Ottoman district, they are assigned the same historical population share.

${ }^{38}$ Since in several instances, multiple districts are assigned to a given Ottoman administrative unit, the 1893 figures for the Armenian and Greek shares capture the exposure of district $i$ to historical Armenian and Greek presence in kaza/sancak $k_{i}$ as well as the exposure of all other modern districts (if any) that are mapped to $k_{i}$, i.e., all $j$ with $k_{j}=k_{i}$. In that sense, the coefficients of interest $\alpha$ and $\gamma$ reflect the kaza/sancak level fixed effect of minorities on modern district outcomes. 
TABle 1: Summary Statistics

\begin{tabular}{|c|c|c|c|c|c|c|c|}
\hline \multirow[b]{2}{*}{ Variable } & \multirow[b]{2}{*}{ Obs } & \multirow[b]{2}{*}{ Mean } & \multirow[b]{2}{*}{ Std. } & \multirow[b]{2}{*}{ Min } & \multirow[b]{2}{*}{$\operatorname{Max}$} & \multicolumn{2}{|c|}{ Percentile } \\
\hline & & & & & & 10th & 90 th \\
\hline \multicolumn{8}{|l|}{ Outcomes } \\
\hline Log population density, 2000 & 757 & 4.11 & 1.06 & 1.71 & 9.34 & 2.97 & 5.39 \\
\hline Urbanization rate, 2000 & 757 & 0.46 & 0.20 & 0.09 & 1.00 & 0.22 & 0.75 \\
\hline $\log (0.01+$ Average Luminosity, 2000) & 757 & 0.76 & 1.05 & -3.43 & 4.00 & -0.55 & 1.98 \\
\hline $\log (0.01+$ Average Luminosity, 2007-2013) & 757 & 1.11 & 0.99 & -2.83 & 4.07 & -0.06 & 2.34 \\
\hline Log population density, 1927 & 757 & 3.04 & 0.68 & 0.14 & 5.21 & 2.24 & 3.77 \\
\hline Log population density, 1881-1893 & 757 & 2.58 & 0.99 & -0.37 & 6.02 & 1.38 & 3.67 \\
\hline Urbanization rate, 1935 & 757 & 0.19 & 0.17 & 0.02 & 1.00 & 0.05 & 0.40 \\
\hline High school competion rate, 2000 & 757 & 0.16 & 0.07 & 0.05 & 0.54 & 0.09 & 0.25 \\
\hline University completion rate, 2000 & 757 & 0.04 & 0.02 & 0.01 & 0.25 & 0.02 & 0.07 \\
\hline Land Holdings Concentration in 1997 & 751 & 0.46 & 0.11 & 0.02 & 0.95 & 0.34 & 0.60 \\
\hline \multicolumn{8}{|l|}{ Variables of Interest } \\
\hline Armenian population share $1881-1893$ & 757 & 0.06 & 0.11 & 0.00 & 0.65 & 0.00 & 0.20 \\
\hline Greek population share $1881-1893$ & 757 & 0.09 & 0.14 & 0.00 & 0.93 & 0.00 & 0.26 \\
\hline (\# of old Armenian school buildings) & 757 & 1.01 & 3.80 & 0.00 & 72.00 & 0.00 & 2.00 \\
\hline (\# of old Greek school buildings) & 757 & 1.29 & 5.01 & 0.00 & 60.00 & 0.00 & 3.00 \\
\hline (\# of old Armenian buildings) & 757 & 3.06 & 9.19 & 0.00 & 154.00 & 0.00 & 7.00 \\
\hline (\# of old Greek buildings) & 757 & 4.87 & 17.94 & 0.00 & 178.00 & 0.00 & 9.00 \\
\hline \multicolumn{8}{|l|}{ Geographical controls } \\
\hline Longitude & 757 & 33.40 & 4.38 & 25.91 & 44.17 & 27.70 & 39.66 \\
\hline Latitude & 757 & 39.31 & 1.48 & 36.08 & 42.02 & 37.34 & 41.16 \\
\hline Mean elevation & 757 & 902.40 & 496.79 & 3.73 & 2551.25 & 211.06 & 1510.27 \\
\hline Standard deviation of elevation & 757 & 256.02 & 149.01 & 5.82 & 948.92 & 93.97 & 441.94 \\
\hline Lake & 757 & 0.29 & 0.45 & 0.00 & 1.00 & 0.00 & 1.00 \\
\hline Sea & 757 & 0.22 & 0.41 & 0.00 & 1.00 & 0.00 & 1.00 \\
\hline Major river & 757 & 0.28 & 0.45 & 0.00 & 1.00 & 0.00 & 1.00 \\
\hline Average annual temperature & 757 & 0.01 & 0.00 & 0.01 & 0.02 & 0.01 & 0.02 \\
\hline Average annual precipitation & 757 & 0.64 & 0.20 & 0.33 & 1.73 & 0.44 & 0.88 \\
\hline Suitability to cultivation of the crop with greatest potential & 757 & 4.19 & 1.66 & 0.24 & 9.34 & 2.04 & 6.44 \\
\hline \multicolumn{8}{|l|}{$\underline{\text { Robustness Controls }}$} \\
\hline Log Distance to Railroad in 1910 & 757 & 10.92 & 1.55 & 3.98 & 12.98 & 8.86 & 12.63 \\
\hline Log Distance to Major 19th century port & 757 & 5.02 & 0.80 & 0.00 & 6.24 & 4.11 & 5.74 \\
\hline Log Distance $(\mathrm{km})$ to war front, $1919-1922$ & 757 & 4.15 & 1.28 & -0.99 & 5.85 & 2.43 & 5.53 \\
\hline Log WW1 soldier casualty from province & 757 & 7.07 & 1.02 & 1.39 & 8.37 & 5.99 & 8.22 \\
\hline Share of immigrants (1921-1929) in 1927 province & 757 & 0.04 & 0.07 & 0.00 & 0.60 & 0.00 & 0.09 \\
\hline Share of Kurdish speakers in 1927 province & 757 & 7.55 & 18.35 & 0.00 & 88.94 & 0.02 & 41.81 \\
\hline Central kaza/sancak & 757 & 0.42 & 0.49 & 0.00 & 1.00 & 0.00 & 1.00 \\
\hline Log Distance to Istanbul & 757 & 6.04 & 0.67 & 3.52 & 7.19 & 5.11 & 6.84 \\
\hline Log Distance to nearest national border $(\mathrm{km})$ & 757 & 5.19 & 0.87 & 1.66 & 6.27 & 4.00 & 6.07 \\
\hline Log Distance to Ottoman Trade Routes & 757 & 10.28 & 0.91 & 7.15 & 11.95 & 9.01 & 11.40 \\
\hline Log Distance to Anatolian Silk Road & 757 & 10.10 & 0.88 & 7.30 & 11.77 & 8.88 & 11.23 \\
\hline \multicolumn{8}{|l|}{ Instruments for historical minority presence } \\
\hline $\log (1+\#$ ancient Greek sites within $20 \mathrm{~km}$ of district centroid $)$ & 757 & 0.26 & 0.48 & 0.00 & 2.30 & 0.00 & 1.10 \\
\hline $\log (1+\#$ ancient Greek sites within $30 \mathrm{~km}$ of district centroid $)$ & 757 & 0.44 & 0.65 & 0.00 & 2.89 & 0.00 & 1.39 \\
\hline $\log (1+\#$ ancient Greek sites within $40 \mathrm{~km}$ of district centroid $)$ & 757 & 0.63 & 0.78 & 0.00 & 3.22 & 0.00 & 1.79 \\
\hline $\log (1+\#$ ancient Greek sites within $50 \mathrm{~km}$ of district centroid $)$ & 757 & 0.82 & 0.89 & 0.00 & 3.64 & 0.00 & 2.08 \\
\hline $\log (1+\#$ ancient Greek sites within 50 to $70 \mathrm{~km}$ of district centroid $)$ & 757 & 0.79 & 0.83 & 0.00 & 3.37 & 0.00 & 2.08 \\
\hline Log Distance to Van & 757 & 6.66 & 0.63 & 0.76 & 7.32 & 5.94 & 7.22 \\
\hline Log Distance to Artashat & 757 & 6.79 & 0.46 & 4.68 & 7.37 & 6.10 & 7.28 \\
\hline Log Distance to Silvan & 757 & 6.39 & 0.72 & -0.16 & 7.19 & 5.58 & 7.06 \\
\hline Log Distance to Sis & 757 & 6.01 & 0.63 & -0.41 & 6.83 & 5.25 & 6.61 \\
\hline
\end{tabular}


would result if the two biggest Christian populations of the Empire showed a tendency to sort into localities where the other group was more or less concentrated. ${ }^{39}$

Our primary goal is to assess whether minority presence made a difference above and beyond its potential influence on historical levels of development. Thus, natural logarithm of population density $P D_{1927}$ in modern district $i$ is included in the model as a proxy for initial economic conditions. ${ }^{40}$ Conditioning on historical population density is essential to make a meaningful comparison between post-expulsion changes in our outcome measures across districts with different historical minority presence. It also allows us to partly account for the bias due to historical selection. While part of historical population density presumably reflects the contribution of Armenians and Greeks on local development, it is also possible that some other determinants of population density in 1927 might at the same time have led to selective migration.

$\mathbf{X}_{\mathbf{i}}$ denotes the vector of geographical determinants of economic potential that we have described in section 4.1. These exogenous factors might have driven early Armenian and Greek settlements in more viable regions of Anatolia, both economically and otherwise. $R_{i}$ denote the fixed effects associated with the modern region/sub-region of district $i$. Finally, we cluster standard errors at the level of modern provinces.

In sum, our identifying assumption for the baseline estimations is that conditional on (i) historical population density, (ii) region specific fixed effects and (iii) geographical factors of historical development and economic activity of the time (i.e. agriculture), which might have driven minority settlement patterns millennia ago, remaining unexplained drivers of contemporary urbanization patterns, population density, and economic activity should not be correlated with minority presence. ${ }^{41}$

\footnotetext{
${ }^{39}$ One potential reason for positive sorting could be the complementarities between Armenian and Greek presence in particular economic activities that require different sets of skills and expertise possessed by the two groups. Another reason could be economies of scale in the provision of religious public goods at the local level. One reason for negative sorting could be the desire to escape from competition in those economic sectors where Greek and Armenian human capital were substitutes rather than complements.

${ }^{40}$ Although we have data on total population in 1893 at the level of Ottoman districts, since there are no welldefined boundaries of these districts, we are not able to compute population density for 1893 . Therefore, we prefer to control for the population density in 1927, the first census of the Turkish Republic. However, when we alternatively use a rough proxy for population density in 1893 as a control for initial development our results remain qualitatively unchanged.

${ }^{41}$ We later relax this assumption when we perform matching and instrumental variable exercises in the robustness analyses, which we will discuss in the corresponding sections.
} 


\section{$5 \quad$ Empirical Results}

\subsection{Minorities and Historical Population Density}

To put our contemporary results in perspective, we first document how regional population dynamics were related to Armenian and Greek presence prior to and in the immediate aftermath of the expulsions. In particular, we would like to supplement the descriptive evidence presented in the historical background section and establish (i) whether there was a meaningful gap in population density back in 1893 between Ottoman districts with high and low minority concentration and (ii) to what extent the expulsions affected population density in districts with considerable Greek and Armenian presence in the short term.

Unless minority presence could already predict some of the regional differences in economic potential prior to the expulsions, a case for persistent legacy would be hard to justify. On the other hand, it is a priori not clear to which extent any pre-expulsion difference in economic potential would be visible in the levels of local development already by the late 19 th century. ${ }^{42}$ In the historical background section, we have shown that Ottoman provinces with above-median minority share had somewhat higher average income per capita in 1894/95 than provinces below the median. Although more disaggregated historical income data are not available for Ottoman districts to verify a similar relationship more systematically, to the extent the Ottoman economy was still governed by Malthusian dynamics back in 1893, population density should serve as a proxy for the level of development. $^{43}$

Figure 6 presents the conditional and unconditional relationships between minority shares and population density in 1893 at the level of Ottoman districts $(k a z a) .{ }^{44}$ The top figure on the left panel shows the residual scatter plots of the correlation between Armenian share and population density conditional on Greek share only. In subsequent figures we first add geographical characteristic, and in the bottom figure we account for Ottoman province (vilayet) fixed effects. First,

\footnotetext{
${ }^{42}$ One should keep in mind that the impact of minority legacy on development may become more pronounced over time if the return to human and physical capital increases with further industrialization and integration with the global economy. Hence, the lack of a significant relationship between minority presence and population density in the late 19th century does not necessarily preclude minority contribution to contemporary development.

${ }^{43}$ In any case, income per capita may not be a suitable measure to look at since in a Malthusian economy, differences in income per capita may understate the actual regional gaps in productivity.

${ }^{44}$ Since kaza boundaries are not directly observable, population density measures are constructed using rough proxies for corresponding areas. Given the extent of measurement error in this variable and the potential for attenuation bias, the results should be taken with a grain of salt.
} 
the unconditional negative relationship simply reflects the fact that the areas where Armenians settled were historically less densely populated. This negative relationship becomes statistically indistinguishable from zero once conditioned on geographical controls. This should not come as a surprise when we consider the historical homeland of Ottoman Armenians. The historical homeland of Ottoman Armenians was situated in the eastern half of Turkey with a significant Armenian concentration in the mountainous interior regions with less than ideal climate and soil conditions for agriculture to allow for dense settlements. It is also worth noting the potential influence of the west-east gradient that historically characterized development potential in Anatolia. Far from the main economic centers in the West and fairly isolated from the central authority, the areas with high Armenian presence were systematically disadvantaged both in terms of exposure to economic spillovers and security. Nonetheless, as the bottom left figure suggests, once we account for the fixed effects at the level of Ottoman provinces (vilayet), we see a strong positive relationship between Armenian share and population density. The three corresponding figures on the right hand side paint a qualitatively different picture for Greeks. Taken together they imply that, unlike Armenians, Greeks were concentrated in areas that were geographically more conducive to high density settlements with greater economic potential. This was already hinted by the settlement patterns depicted in Figure 3. Once we control for geographical attributes the relationship becomes weaker in magnitude but remains highly significant. However, in the presence of province fixed effects, the positive relationship disappears.

Next, to explore the short-term impact of expulsions on regional population density, we regress population density in 1927 on historical minority presence at the level districts back in 1927. Since we want to isolate the impact of expulsions as much as possible, we need to compare districts with similar levels of population density before the expulsions. Hence, we control for population density in 1893 in all these regressions. Figure 7 summarizes a subset of our results where, besides pre-expulsion population density, we control for a set of geographical features and sub-region fixed effects.

The striking negative correlations for both Armenians and Greeks in the top panel of Figure 7 are consistent with the mechanical impact of deportations and the population exchange in reducing population density. Among areas with similar levels of population density before the Armenian deportation, those inhabited by a higher share of Armenians were significantly less 

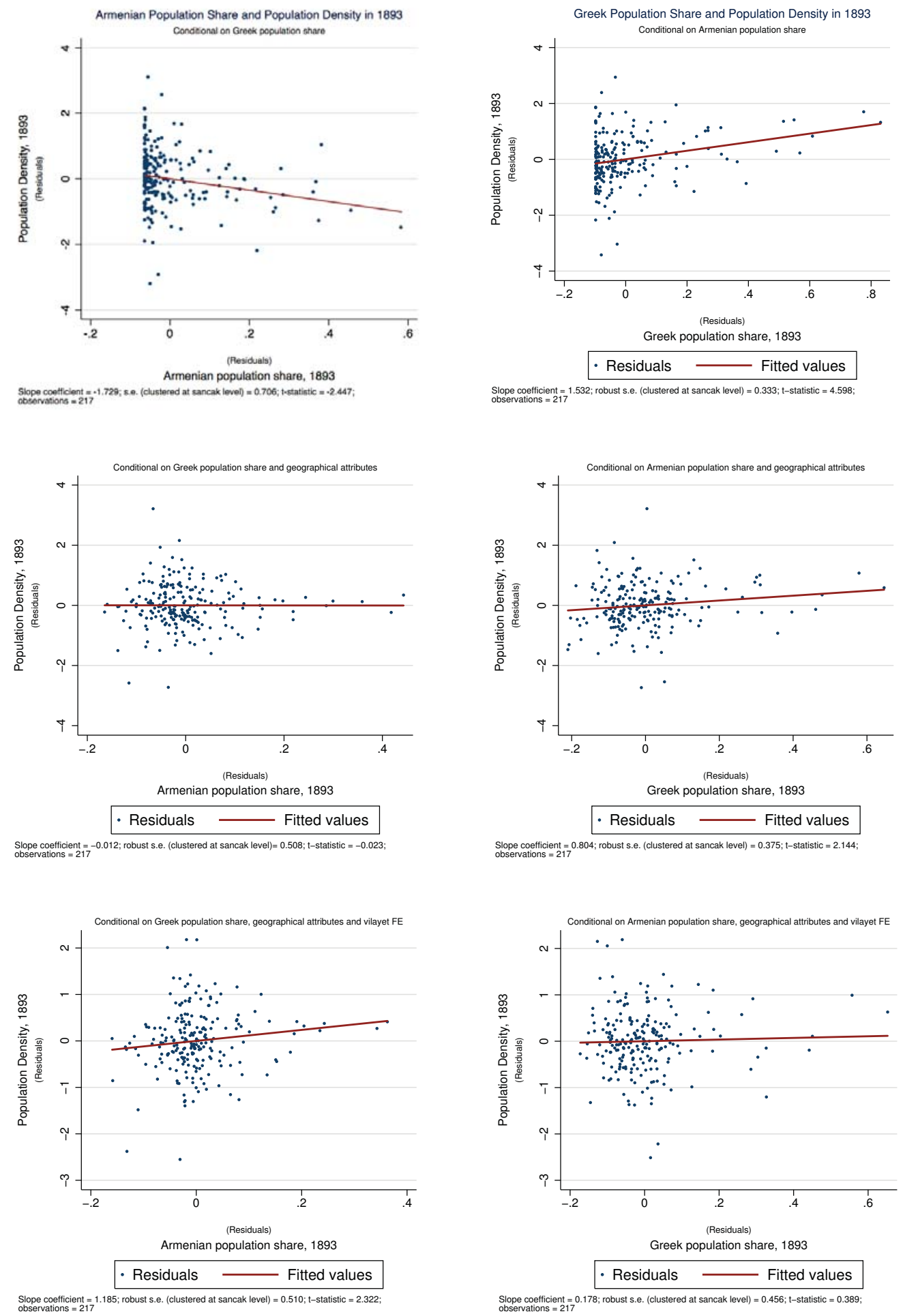

FiguRE 6: Pre-expulsion conditions: Minority shares and population density in 1893 

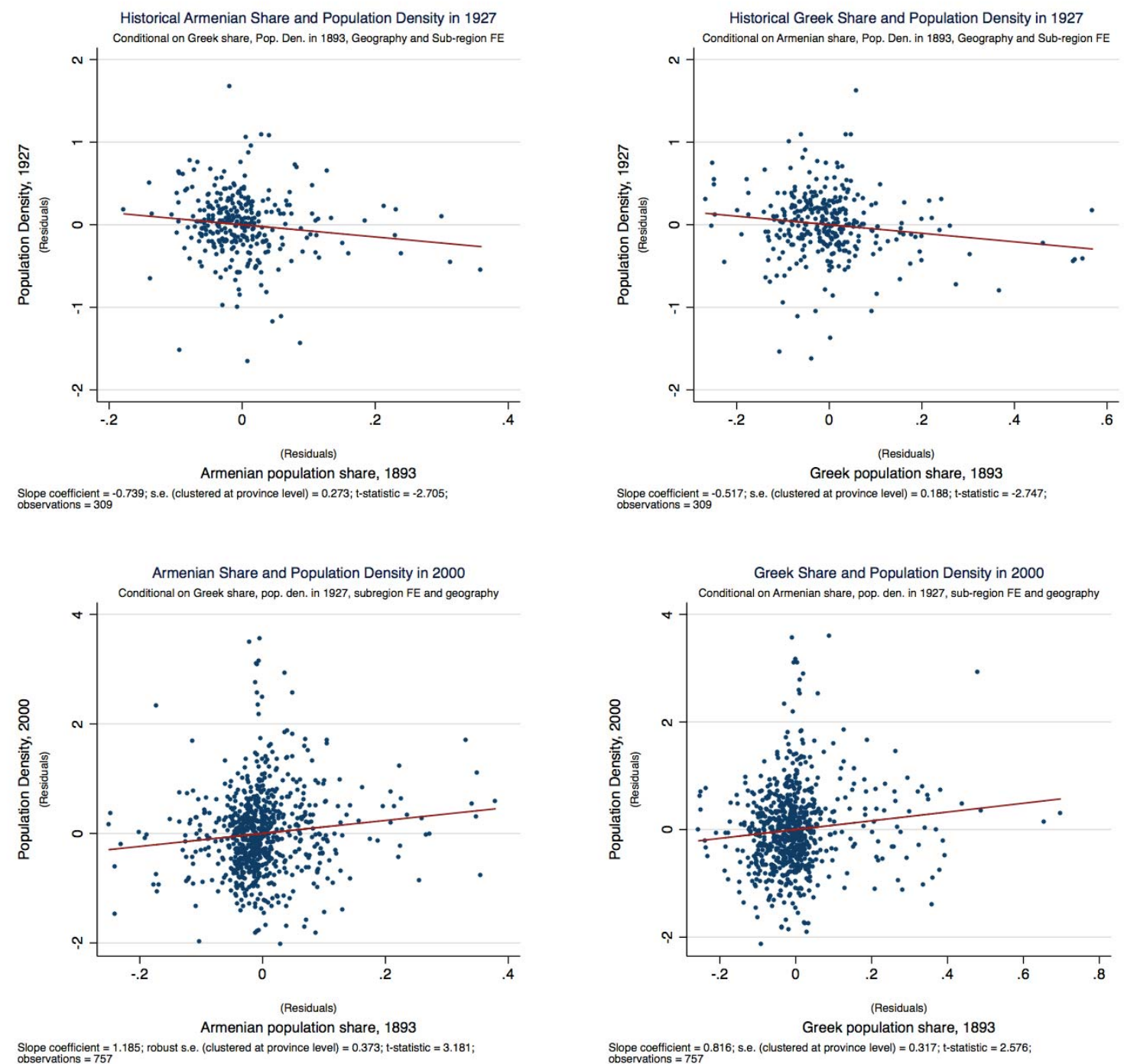

FIgURE 7: The short-term impact of expulsions and the long-run legacy of minority presence on population density

populated ten years after the expulsions and mass killings. A similar conclusion holds for the impact of Greek expulsions, and both relationships are robust to conditioning on geographical attributes as well as fixed effects at the region or sub-region level.

As we show in subsequent sections, in the longer-run, the recovery process not only eliminated the post-expulsion density gap between low- and high-minority areas, but it eventually led to the (re)emergence of significant differences in population density in favor of the latter. The bottom panel of Figure 7 offers a first-pass illustration of the positive legacy of minorities in the 
long-run. ${ }^{45}$ Moreover, we later show that these differences mirror differences in urbanization and economic activity. Taken together, these findings are consistent with our persistence hypothesis and presumably reflect what we call the positive legacy of Armenians and Greeks. Analyzing contemporary population densities, the next section offers the first piece of evidence consistent with the persistence hypothesis we have just outlined.

\subsection{Minorities and Population Density}

If Armenian and Greek minorities contributed to regional development in a persistent way one would expect contemporary population density to be systematically higher in areas with greater Armenian and Greek presence. To verify if this conjecture is supported by data, we first use population density of a district in 2000 as our outcome measure. We view population density as an indicator reflecting the degree of economic opportunities and the capacity to sustain higher concentrations of people. Albeit a highly noisy proxy for contemporary development, population density is a good starting point at least in our attempt to understand the potential legacy of minorities on current demographic patterns. To see if population density in high-minority regions grew faster over the Republican period, we also add population density in 1927 to the right hand side.

Table 2 presents the results. To highlight the distinction between short-run impact of expulsions from the long-run comparison of the levels of population density across high and low minority districts, in Panel A we first report the full set of results for population density in 1927. Part of these results have already been summarized by the partial correlation plots in Figure 7 . Panel B presents the partial correlations of population density in 2000 with Armenian and Greek population shares. ${ }^{46}$ In each panel, we start with a specification that only includes historical minority shares and past population density. Then, we add a set of dummies for each of the seven geographic regions of Turkey. ${ }^{47}$ In the third column, we add latitude and longitude, and continue expanding our model with the remaining set of geographical controls until we reach column (7).

\footnotetext{
${ }^{45}$ We provide more detail on this point in the next subsection and in Table 2.

${ }^{46}$ All our results remain qualitatively intact when we include Greek and Armenian shares separately or if we control for population density prior to mass expulsions instead of density in 1927.

${ }^{47}$ These regions are the Marmara, Mediterranean, Aegean, Black Sea, Middle Anatolia, Eastern Anatolia and Southeastern Anatolia. They are not administrative regions. When defining them geographers considered similarity of provinces with respect to geographical factors such as climate, vegetation, presence of mountain ranges, and also some economic factors such as demographics, transportation and type of products cultivated.
} 
In the next column we replace the modern region dummies with 21 geographic subregion dummies to obtain our baseline model. Finally, in the last column, we run the most stringent specification by allowing for 81 province fixed effects. In all regressions, reported standard errors are clustered at the level of a modern province. ${ }^{48}$ Unless stated otherwise, we report the percentage change in the level of outcome variables in response to increasing our variable of interest from the 10th to the 90th percentile of its cross-district distribution in the sample. This is equivalent to raising Armenian and Greek shares in total population from 0 to 20 percent and from 0 to 26 percent, respectively.

Moving to results in panel A, both Armenian and Greek shares in 1893 appear as negative and statistically significant correlates of district population density in 1927 in most specifications. This is not surprising given that it must have taken quite some time for population levels in these regions to recover after mass expulsions. According to the baseline specification in column (8), population density in 1927 in a district with 20 percent historical Armenian share was almost 15 percent lower than in a similar district without Armenians. Comparing the two minority share coefficients we see that an increase in population shares of both groups by the same amount is associated with a somewhat stronger decline in density for Armenians. However, the difference in marginal effects of moving from the 10th to the 90th percentile is bigger for Greeks given that 90th percentile in the Greek distribution corresponds to a higher population share than it does in the Armenian distribution. In a district at the 90th percentile of the Greek share distribution, population density is predicted to be about 17 percent lower in 1927 relative to a district at the 10th percentile of the same distribution.

Results for population density in 2000 are reported in panel B. They are qualitatively opposite of the results for 1927 density regressions. Districts with greater concentration of historical minorities are more densely populated in 2000. This reversal in the relationship supports our view that despite enduring more pronounced negative shocks to population due to expulsions, over the longer term, regions with relatively greater Armenian and Greek presence nonetheless managed to takeover their ethno-religiously more homogenous counterparts. As reported at the bottom of panel $\mathrm{B}$, the marginal effects of a from-10th-to-90th percentile move are 23 and 21 percent increases in

\footnotetext{
${ }^{48}$ Administratively, multiple modern districts fall under the jurisdiction of a province. Hence, our choice of clustering unit allows for arbitrary correlation of disturbance terms across districts that are assigned to the same province.
} 
TABle 2: Historical Minority Shares and Population Densities in 1927 and 2000

\begin{tabular}{|c|c|c|c|c|c|c|c|c|c|}
\hline \multirow{3}{*}{ PANEL A } & \multicolumn{9}{|c|}{ Log(Population density in 1927$)$} \\
\hline & (1) & $(2)$ & (3) & (4) & (5) & (6) & (7) & $\begin{array}{l}(8) \\
(8)\end{array}$ & (9) \\
\hline & & OLS & OLS & OLS & OLS & OLS & & & \\
\hline \multirow[t]{2}{*}{ Armenian population share, $1881-1893$} & -0.929 & -0.746 & -0.983 & -0.719 & -0.744 & -0.712 & -0.713 & $-0.739 * * *$ & $-0.566^{*}$ \\
\hline & {$[0.653]$} & {$[0.699]$} & {$[0.648]$} & {$[0.534]$} & {$[0.533]$} & {$[0.529]$} & {$[0.531]$} & {$[0.273]$} & {$[0.298]$} \\
\hline \multirow[t]{2}{*}{ Greek population share, 1881-1893 } & 0.195 & $-0.344^{*}$ & $-0.348^{*}$ & $-0.548^{* * *}$ & $-0.530^{* * *}$ & $-0.500^{* * *}$ & $-0.505^{* * *}$ & $-0.517^{* * *}$ & $-0.522^{* *}$ \\
\hline & {$[0.346]$} & {$[0.175]$} & {$[0.189]$} & {$[0.165]$} & {$[0.177]$} & {$[0.178]$} & {$[0.187]$} & {$[0.188]$} & {$[0.225]$} \\
\hline \multirow[t]{2}{*}{ Proxy for population density in 1893} & $0.283^{*}$ & 0.211 & 0.203 & 0.199 & 0.199 & 0.197 & 0.196 & $0.487^{* * *}$ & $0.439^{* * *}$ \\
\hline & {$[0.157]$} & {$[0.146]$} & {$[0.138]$} & {$[0.122]$} & {$[0.123]$} & {$[0.121]$} & {$[0.121]$} & {$[0.142]$} & {$[0.162]$} \\
\hline Effect of increasing Armenian share & -18.431 & -14.814 & -19.510 & -14.276 & -14.758 & -14.132 & -14.155 & $-14.669^{* * *}$ & $-11.242^{*}$ \\
\hline from the 10 -th to the 90 -th percentile & {$[12.951]$} & {$[13.864]$} & {$[12.870]$} & {$[10.591]$} & {$[10.574]$} & {$[10.493]$} & {$[10.532]$} & {$[5.422]$} & {$[5.920]$} \\
\hline Effect of increasing Greek share & 6.337 & $-11.211^{* *}$ & $-11.325^{*}$ & $-17.838^{* * *}$ & $-17.243^{* * *}$ & $-16.287^{* * *}$ & $-16.441^{* * *}$ & $-16.826^{* * *}$ & $-16.997^{* *}$ \\
\hline from the 10 -th to the 90 -th percentile & {$[11.259]$} & {$[5.694]$} & {$[6.160]$} & {$[5.362]$} & {$[5.747]$} & {$[5.793]$} & {$[6.080]$} & {$[6.126]$} & {$[7.329]$} \\
\hline Observations & 309 & 309 & 309 & 309 & 309 & 309 & 309 & 309 & 309 \\
\hline \multirow[t]{2}{*}{ Adjusted R-squared } & 0.246 & 0.366 & 0.378 & 0.461 & 0.458 & 0.457 & 0.455 & 0.610 & 0.626 \\
\hline & \multicolumn{9}{|c|}{ Log(Population density in 2000$)$} \\
\hline \multirow[t]{2}{*}{ PANEL B } & $(1)$ & $(2)$ & $(3)$ & $(4)$ & $(5)$ & $(6)$ & $(7)$ & $(8)$ & $(9)$ \\
\hline & OLS & OLS & OLS & OLS & OLS & OLS & OLS & OLS & OLS \\
\hline \multirow[t]{2}{*}{ Armenian population share, $1881-1893$} & $1.393^{* * *}$ & $1.395^{* *}$ & $1.481^{* * *}$ & $1.588^{* * *}$ & $1.615^{* * *}$ & $1.524^{* * *}$ & $1.518^{* * *}$ & $1.185^{* * *}$ & $1.024^{* *}$ \\
\hline & {$[0.451]$} & {$[0.532]$} & {$[0.423]$} & {$[0.460]$} & {$[0.392]$} & {$[0.409]$} & {$[0.380]$} & {$[0.373]$} & {$[0.454]$} \\
\hline \multirow[t]{2}{*}{ Greek population share, 1881-1893 } & $0.970^{* * *}$ & $1.325^{* * *}$ & $1.390^{* * *}$ & $0.950^{* * *}$ & $0.712^{* * *}$ & $0.714^{* * *}$ & $0.931^{* * *}$ & $0.816^{* *}$ & 0.466 \\
\hline & {$[0.340]$} & {$[0.318]$} & {$[0.322]$} & {$[0.264]$} & {$[0.263]$} & {$[0.269]$} & {$[0.282]$} & {$[0.317]$} & {$[0.295]$} \\
\hline \multirow[t]{2}{*}{ Log(Population density, 1927) } & $0.826^{* * *}$ & $0.918^{* * *}$ & $0.945^{* * *}$ & $0.765^{* * *}$ & $0.756^{* * *}$ & $0.765^{* * *}$ & $0.775^{* * *}$ & $0.814^{* * *}$ & $0.806 * * *$ \\
\hline & {$[0.098]$} & {$[0.103]$} & {$[0.096]$} & {$[0.105]$} & {$[0.096]$} & {$[0.092]$} & {$[0.095]$} & {$[0.090]$} & {$[0.110]$} \\
\hline \multirow{4}{*}{$\begin{array}{l}\text { Effect of increasing Armenian share } \\
\text { from the } 10 \text {-th to the } 90 \text {-th percentile } \\
\text { Effect of increasing Greek share } \\
\text { from the } 10 \text {-th to the } 90 \text {-th percentile }\end{array}$} & $27.637^{* * *}$ & $27.686^{* * *}$ & $29.398^{* * *}$ & $31.521^{* * *}$ & $32.053^{* * *}$ & $30.256^{* * *}$ & $30.129^{* * *}$ & $23.524^{* * *}$ & $20.326^{* *}$ \\
\hline & {$[8.953]$} & {$[10.560]$} & {$[8.391]$} & {$[9.128]$} & {$[7.788]$} & {$[8.120]$} & {$[7.549]$} & [7.395] & {$[9.008]$} \\
\hline & $24.946^{* * *}$ & $34.053^{* * *}$ & $35.743^{* * *}$ & $24.427^{* * *}$ & $18.309^{* * *}$ & $18.359^{* * *}$ & $23.937^{* * *}$ & $20.973^{* * *}$ & 11.986 \\
\hline & {$[8.751]$} & {$[8.185]$} & {$[8.283]$} & {$[6.798]$} & {$[6.756]$} & {$[6.905]$} & {$[7.243]$} & {$[8.141]$} & {$[7.595]$} \\
\hline Observations & 757 & 757 & 757 & 757 & 757 & 757 & 757 & 757 & 757 \\
\hline Adjusted R-squared & 0.304 & 0.325 & 0.332 & 0.421 & 0.440 & 0.441 & 0.454 & 0.480 & 0.521 \\
\hline Longitude \& Latitude & & & $\checkmark$ & $\checkmark$ & $\checkmark$ & $\checkmark$ & $\checkmark$ & $\checkmark$ & $\checkmark$ \\
\hline Mean \& std. of elevation & & & & $\checkmark$ & $\checkmark$ & $\checkmark$ & $\checkmark$ & $\checkmark$ & $\checkmark$ \\
\hline Lake, sea and major rivers & & & & & $\checkmark$ & $\checkmark$ & $\checkmark$ & $\checkmark$ & $\checkmark$ \\
\hline Temperature \& Precipitation & & & & & & $\checkmark$ & $\checkmark$ & $\checkmark$ & $\checkmark$ \\
\hline Suitability to cultivation & & & & & & & $\checkmark$ & $\checkmark$ & $\checkmark$ \\
\hline Modern region dummies & & $\checkmark$ & $\checkmark$ & $\checkmark$ & $\checkmark$ & $\checkmark$ & $\checkmark$ & & \\
\hline Modern subregion dummies & & & & & & & & $\checkmark$ & \\
\hline Modern province dummies & & & & & & & & & $\checkmark$ \\
\hline
\end{tabular}

Notes: This table presents results from the regressions of Log Population Density in 1927 and Log Population Density in 2000 on historical minority shares controlling for past population density, geographical variables, region, subregion or province fixed effects. The estimated effect associated with increasing minority shares from the tenth to the ninetieth percentile of their respective cross-district distributions is expressed in terms of $\%$ change in the level of population density. Robust standard errors, clustered at the modern Turkish province (il) level, are reported in square $\%$ change in the level of population density. Robust standard errors, clustered at the modern Turkish province (il) level,
brackets. $* * *$ denotes statistical significance at the 1 percent level, ** at the 5 percent level, and * at the 10 percent level.

2000 population density, for Armenians and Greeks respectively, although the marginal effect for Armenians is larger when we consider an increase in population shares by the same amount.

Note that it is crucial to condition on geographic, climatic, and topographical features (mean and standard deviation of elevation). When we compare columns (2) through (7) we observe that the coefficient on Armenian share increases. Especially, when elevation and its standard deviation are not controlled for Armenian share coefficient is downward biased (see columns (2)- 
(4)). Today, perhaps more than in the past, areas of higher altitude and rough terrain are relatively less populated, and our regressions - not shown here- confirm that even within a geographical region Armenians tended to inhabit areas with greater elevation. ${ }^{49}$ These two observations explain why omitting the mean and standard deviation of elevation introduces a downward bias in the estimates, hence demonstrating an important instance in which Armenian settlement patterns were characterized by strong negative selection. For Greeks, on the other hand, the point estimates, albeit remaining highly significant all throughout, moves in the opposite direction when we control for topography and geography (see columns (2) to (7)), possibly reflecting the fact that Greeks historically concentrated in coastal regions with significantly lower altitude and standard deviation of elevation. This finding presumably points to a positive selection bias for Greeks. However, the fact that the estimated coefficients of interest -both for Greeks and Armenians- remain fairly stable across the remaining columns is reassuring, suggesting that selection on geographical attributes are unlikely to be responsible for the positive correlations we find. ${ }^{50}$

\subsection{Minorities and Urbanization}

Historically, Greeks and Armenians are known to be more urbanized communities than the Muslims of the Ottoman Empire. Therefore the minority legacy on urban growth should be visible both in the historical and contemporary urbanization rates. In particular, prior to the expulsions, urbanization rates in high minority regions should be systematically higher; and if the possibly negative impact of expulsions are not strong enough to offset the initial gaps in urbanization, then a similar relationship should hold also for the post-expulsion period. ${ }^{51}$

To assess this argument, in Table 3 we use urbanization rates in 1935 and 2000 as our outcome measures. The operational definition of urbanization rate is the fraction of district

\footnotetext{
${ }^{49}$ Our findings also suggest that, conditional on elevation, Armenians tended to concentrate in less mountainous areas. This is consistent with the fact that, being a relatively more sedentary and urbanized community, they settled in less mountainous areas than the Muslims of the same region. Also, a significant part of the Muslim population of the Eastern Provinces consisted of predominantly Kurdish nomadic pastoralists.

${ }^{50}$ In Online Appendix Table S.1 we repeat the contemporary analysis in panel B of Table 2 using a larger sample that also includes the regions where the Ottoman census of 1881-1893 was incomplete. For these regions, we employ estimated figures for uncounted populations and make adjustments to reported counts of such Ottoman districts. The results remain qualitatively unaffected.

${ }^{51}$ For example, if minorities were historically a driving force behind urbanization, then Muslims who were already living in or selecting into high minority districts could over time become more urbanized than Muslims elsewhere. Then historically high minority regions would remain more urbanized than other regions even after the mass expulsions of Armenians and Greeks.
} 
TABle 3: Historical Minority Shares and Urbanization Rates in 1935 and 2000

\begin{tabular}{|c|c|c|c|c|c|c|c|c|c|}
\hline \multirow[b]{2}{*}{ PANEL A } & \multicolumn{9}{|c|}{ Urbanization rate in 1935} \\
\hline & $\begin{array}{l}(1) \\
\text { OLS }\end{array}$ & $\begin{array}{l}(2) \\
\text { OLS } \\
\end{array}$ & $\begin{array}{l}(3) \\
\text { OLS }\end{array}$ & $\begin{array}{l}(4) \\
\text { OLS }\end{array}$ & $\begin{array}{l}(5) \\
\text { OLS }\end{array}$ & $\begin{array}{c}(6) \\
\text { OLS } \\
\end{array}$ & $\begin{array}{l}(7) \\
\text { OLS }\end{array}$ & $\begin{array}{l}(8) \\
\text { OLS }\end{array}$ & $\begin{array}{l}(9) \\
\text { OLS }\end{array}$ \\
\hline Armenian population share, $1881-1893$ & $\begin{array}{c}0.120^{* * *} \\
{[0.042]}\end{array}$ & $\begin{array}{l}0.132^{* *} \\
{[0.065]}\end{array}$ & $\begin{array}{l}0.270^{* * *} \\
{[0.073]}\end{array}$ & $\begin{array}{c}0.285^{* * *} \\
{[0.074]}\end{array}$ & $0.281^{* * *}$ & $0.300^{* * *}$ & $0.304 * * *$ & $0.239 * * *$ & $\begin{array}{c}0.216^{* *} \\
{[0.089]}\end{array}$ \\
\hline Greek population share, 1881-1893 & $\begin{array}{c}0.325^{* * *} \\
{[0.046]}\end{array}$ & $\begin{array}{c}0.299^{* * *} \\
{[0.050]}\end{array}$ & $\begin{array}{c}0.285^{* * *} \\
{[0.051]}\end{array}$ & $\begin{array}{c}0.265^{* * *} \\
{[0.054]}\end{array}$ & $\begin{array}{c}0.264^{* * *} \\
{[0.059]}\end{array}$ & $\begin{array}{c}0.235^{* * *} \\
{[0.062]}\end{array}$ & $\begin{array}{c}0.252^{* * *} \\
{[0.063]}\end{array}$ & $\begin{array}{c}0.240^{* * *} \\
{[0.079]}\end{array}$ & $\begin{array}{c}0.179 \\
{[0.108]}\end{array}$ \\
\hline Proxy for population density in 1893 & $\begin{array}{c}0.021^{* *} \\
{[0.009]}\end{array}$ & $\begin{array}{c}0.030^{* * *} \\
{[0.009]}\end{array}$ & $\begin{array}{c}0.031^{* * *} \\
{[0.010]}\end{array}$ & $\begin{array}{c}0.031^{* * *} \\
{[0.009]}\end{array}$ & $\begin{array}{c}0.031^{* * *} \\
{[0.009]}\end{array}$ & $\begin{array}{c}0.032^{* * *} \\
{[0.009]}\end{array}$ & $\begin{array}{c}0.035^{* * *} \\
{[0.009]}\end{array}$ & $\begin{array}{c}0.052^{* * *} \\
{[0.015]}\end{array}$ & $\begin{array}{c}0.056^{* * *} \\
{[0.019]}\end{array}$ \\
\hline $\begin{array}{l}\text { Effect of increasing Armenian share } \\
\text { from the } 10 \text {-th to the } 90 \text {-th percentile }\end{array}$ & $\begin{array}{c}2.378^{* * *} \\
{[0.840]}\end{array}$ & $\begin{array}{c}2.627^{* *} \\
{[1.295]}\end{array}$ & $\begin{array}{c}5.363^{* * *} \\
{[1.449]}\end{array}$ & $\begin{array}{c}5.651^{* * *} \\
{[1.474]}\end{array}$ & $\begin{array}{c}5.567^{* * *} \\
{[1.501]}\end{array}$ & $\begin{array}{c}5.960^{* * *} \\
{[1.495]}\end{array}$ & $\begin{array}{c}6.040^{* * *} \\
{[1.493]}\end{array}$ & $\begin{array}{c}4.737^{* * *} \\
{[1.559]}\end{array}$ & $\begin{array}{l}4.282^{* *} \\
{[1.770]}\end{array}$ \\
\hline $\begin{array}{l}\text { Effect of increasing Greek share } \\
\text { from the 10-th to the } 90 \text {-th percentile }\end{array}$ & $\begin{array}{c}10.597^{* * *} \\
{[1.490]}\end{array}$ & $\begin{array}{c}9.749^{* * *} \\
{[1.638]}\end{array}$ & $\begin{array}{c}9.273^{* * *} \\
{[1.675]} \\
\end{array}$ & $\begin{array}{c}8.636^{* * *} \\
{[1.755]}\end{array}$ & $\begin{array}{c}8.587^{* * *} \\
{[1.906]}\end{array}$ & $\begin{array}{c}7.658^{* * *} \\
{[2.008]}\end{array}$ & $\begin{array}{c}8.204^{* * *} \\
{[2.066]}\end{array}$ & $\begin{array}{c}7.798^{* * *} \\
{[2.582]}\end{array}$ & $\begin{array}{l}5.822^{*} \\
{[3.507]}\end{array}$ \\
\hline \multirow[t]{2}{*}{ Adjusted R-squared } & $\begin{array}{c}309 \\
0.198\end{array}$ & $\begin{array}{c}309 \\
0.253\end{array}$ & $\begin{array}{c}309 \\
0.278\end{array}$ & $\begin{array}{c}309 \\
0.286\end{array}$ & $\begin{array}{c}309 \\
0.284\end{array}$ & $\begin{array}{c}309 \\
0.292\end{array}$ & $\begin{array}{c}309 \\
0.298\end{array}$ & $\begin{array}{c}309 \\
0.292\end{array}$ & $\begin{array}{c}309 \\
0.263\end{array}$ \\
\hline & \multicolumn{9}{|c|}{ Urbanization rate in 2000} \\
\hline PANEL B & $\begin{array}{l}(1) \\
\text { OLS }\end{array}$ & $\begin{array}{l}(2) \\
\text { OLS }\end{array}$ & $\begin{array}{l}(3) \\
\text { OLS }\end{array}$ & $\begin{array}{l}(4) \\
\text { OLS }\end{array}$ & $\begin{array}{l}(5) \\
\text { OLS }\end{array}$ & $\begin{array}{l}(6) \\
\text { OLS }\end{array}$ & $\begin{array}{l}(7) \\
\text { OLS }\end{array}$ & $\begin{array}{l}(8) \\
\text { OLS }\end{array}$ & $\begin{array}{l}(9) \\
\text { OLS }\end{array}$ \\
\hline Armenian population share, $1881-1893$ & $\begin{array}{c}0.252^{* * *} \\
{[0.095]}\end{array}$ & $\begin{array}{c}0.269^{* * *} \\
{[0.089]}\end{array}$ & $\begin{array}{c}0.344^{* * *} \\
{[0.094]}\end{array}$ & $\begin{array}{c}0.345^{* * *} \\
{[0.091]}\end{array}$ & $\begin{array}{c}0.355^{* * *} \\
{[0.090]}\end{array}$ & $\begin{array}{c}0.392^{* * *} \\
{[0.086]}\end{array}$ & $\begin{array}{c}0.391 * * * \\
{[0.083]}\end{array}$ & $\begin{array}{c}0.466^{* * *} \\
{[0.091]}\end{array}$ & $\begin{array}{c}0.486^{* * *} \\
{[0.096]}\end{array}$ \\
\hline Greek population share, $1881-1893$ & $\begin{array}{l}0.136^{* *} \\
{[0.061]}\end{array}$ & $\begin{array}{c}0.205^{* * *} \\
{[0.066]}\end{array}$ & $\begin{array}{l}0.208^{* * *} \\
{[0.063]}\end{array}$ & $\begin{array}{c}0.177^{* * *} \\
{[0.065]}\end{array}$ & $\begin{array}{c}0.174^{* * *} \\
{[0.065]}\end{array}$ & $\begin{array}{c}0.168^{* * *} \\
{[0.063]}\end{array}$ & $\begin{array}{c}0.206^{* * *} \\
{[0.064]}\end{array}$ & $\begin{array}{l}0.194^{* * *} \\
{[0.061]}\end{array}$ & $\begin{array}{c}0.265^{* * *} \\
{[0.074]}\end{array}$ \\
\hline Log(Population density, 1927) & $\begin{array}{c}0.064^{* * *} \\
{[0.020]}\end{array}$ & $\begin{array}{c}0.096^{* * *} \\
{[0.020]}\end{array}$ & $\begin{array}{c}0.099^{* * *} \\
{[0.019]}\end{array}$ & $\begin{array}{c}0.088^{* * *} \\
{[0.020]}\end{array}$ & $\begin{array}{c}0.087^{* * *} \\
{[0.020]}\end{array}$ & $\begin{array}{c}0.084^{* * *} \\
{[0.020]}\end{array}$ & $\begin{array}{c}0.085^{* * *} \\
{[0.020]}\end{array}$ & $\begin{array}{c}0.093^{* * *} \\
{[0.022]}\end{array}$ & $\begin{array}{c}0.105^{* * *} \\
{[0.022]}\end{array}$ \\
\hline $\begin{array}{l}\text { Effect of increasing Armenian share } \\
\text { from the 10-th to the } 90 \text {-th percentile }\end{array}$ & $\begin{array}{c}5.002^{* * *} \\
{[1.883]}\end{array}$ & $\begin{array}{c}5.346^{* * *} \\
{[1.761]}\end{array}$ & $\begin{array}{c}6.827^{* * *} \\
{[1.870]}\end{array}$ & $\begin{array}{c}6.853^{* * *} \\
{[1.800]}\end{array}$ & $\begin{array}{c}7.040^{* * *} \\
{[1.782]}\end{array}$ & $\begin{array}{c}7.781 * * * \\
{[1.701]}\end{array}$ & $\begin{array}{c}7.759^{* * * *} \\
{[1.656]}\end{array}$ & $\begin{array}{c}9.257^{* * *} \\
{[1.812]}\end{array}$ & $\begin{array}{c}9.651^{* * * *} \\
{[1.899]}\end{array}$ \\
\hline $\begin{array}{l}\text { Effect of increasing Greek share } \\
\text { from the } 10 \text {-th to the } 90 \text {-th percentile }\end{array}$ & $\begin{array}{c}3.507^{* *} \\
{[1.556]}\end{array}$ & $\begin{array}{c}5.259^{* * *} \\
{[1.697]}\end{array}$ & $\begin{array}{c}{\left[1.012^{* * *}\right.} \\
{[1.626]}\end{array}$ & $\begin{array}{c}{\left[.561^{* * *}\right.} \\
{[1.680]}\end{array}$ & $\begin{array}{c}{\left[1.181^{* * *}\right.} \\
{[1.678]}\end{array}$ & $\begin{array}{c}{\left[.325^{* * *}\right.} \\
{[1.609]}\end{array}$ & $\begin{array}{c}{[1.0001} \\
{[1.651]}\end{array}$ & $\begin{array}{c}{\left[1.080^{* * *}\right.} \\
{[1.574]}\end{array}$ & $\begin{array}{c}{\left[1.001^{* * *}\right.} \\
{[1.907]}\end{array}$ \\
\hline Observations & 757 & 757 & 757 & 757 & 757 & 757 & 757 & 757 & 757 \\
\hline Adjusted R-squared & 0.062 & 0.102 & 0.107 & 0.117 & 0.118 & 0.125 & 0.136 & 0.151 & 0.205 \\
\hline Longitude \& Latitude & & & $\checkmark$ & $\checkmark$ & $\checkmark$ & $\checkmark$ & $\checkmark$ & $\checkmark$ & $\checkmark$ \\
\hline Mean \& std. of elevation & & & & $\checkmark$ & $\checkmark$ & $\checkmark$ & $\checkmark$ & $\checkmark$ & $\checkmark$ \\
\hline Lake, sea and major rivers & & & & & $\checkmark$ & $\checkmark$ & $\checkmark$ & $\checkmark$ & $\checkmark$ \\
\hline Temperature \& Precipitation & & & & & & $\checkmark$ & $\checkmark$ & $\checkmark$ & $\checkmark$ \\
\hline Suitability to cultivation & & & & & & & $\checkmark$ & $\checkmark$ & $\checkmark$ \\
\hline Modern region dummies & & $\checkmark$ & $\checkmark$ & $\checkmark$ & $\checkmark$ & $\checkmark$ & $\checkmark$ & & \\
\hline Modern subregion dummies & & & & & & & & $\checkmark$ & \\
\hline Modern province dummies & & & & & & & & & $\checkmark$ \\
\hline
\end{tabular}

Notes: This table presents results from the regressions of Urbanization Rate in 1935 and Urbanization Rate in 2000 on historical minority shares controlling for past population density, geographical variables, region, subregion or province fixed effects. The estimated effect associated with increasing minority shares from the tenth to the ninetieth percentile of their respective cross-district distributions is expressed in terms of percentage-point change in the urbanization rates. Robust standard errors, clustered at the modern Turkish province $(i l)$ level, are reported in square brackets. *** denotes statistical significance at the 1 percent level, ** at the 5 percent level, and ${ }^{*}$ at the 10 percent level.

population living within the borders that define district centers. While we view this measure primarily as a proxy for the degree of economic modernization at the local level, it can also be a proxy for income per capita at large both for early and more recent periods. ${ }^{52}$

\footnotetext{
${ }^{52}$ Acemoglu et al. (2002) estimate positive and strong cross-country correlations between urbanization and income per capita for early 20th century, mid-20th century and more recent time periods.
} 
Panel A of Table 3 presents the association between urbanization rates in 1935 (first year for which we have data on urbanization) and historical minority presence. Unlike the mechanical negative effect of expulsions on post-expulsion population densities, we would not necessarily expect to see a direct mechanical impact of expulsions on urbanization rates. This is because minorities lived in both urban and rural areas and they were all expelled. Our results are consistent with this prior. Districts with larger historical minority presence are more urbanized in 1935 even after expulsions compared to the districts with high Muslim concentration.

Moving to Panel B of Table 3 we observe that districts with higher historical exposure to minority presence are significantly more urbanized in 2000 even after controlling for the baseline geographical characteristics and region fixed effect. These results are also robust to more stringent specifications controlling for subregion or province fixed effects. The coefficient estimates from the baseline model in column (8) suggest that, keeping other variables constant, a move from the 10th to the 90th percentile of the regional distribution of Armenian population shares is associated with an increase in urbanization rate by 9.2 percentage points, a change that is statistically significant at the 1 percent level. The evidence on Greeks is qualitatively similar, but smaller in magnitude. The positive association between Greek population share and urbanization rate -with an estimated change of around 5 percentage points in urbanization rate under the baseline model- is also significant at the 1 percent level. ${ }^{53}$

It is important to reiterate that part of the correlation between Greek and Armenian presence and urbanization rates might simply be an artifact of selection of minorities on historical urbanization patterns and the persistence of the latter into contemporary period. This however does not preclude the idea that regional disparity in historical urbanization rates were partly shaped by long-term presence of Greek and Armenian communities and their contribution to economic development. Many provinces and districts that are significantly more urbanized today were possibly not so much ahead of other regions at some distant past, prior to the settlement of first Greek and Armenian groups. Therefore, the evidence in Table 3 can be interpreted in two different ways, but which interpretation plays a more significant role is empirically hard to identify.

\footnotetext{
${ }^{53}$ Like before, in Online Appendix Table S.1 we rerun the regressions in Table 3 using a larger sample that also includes the regions where the Ottoman census of 1881-1893 was incomplete, and the adjusted minority share. The results are quite similar both in terms statistical significance and estimated magnitudes.
} 


\subsection{Minority Legacy on Nighttime Lights}

\subsubsection{Baseline Analysis of Minority Legacy}

Our third and the main outcome variable is luminosity, i.e., average light intensity measured from satellite images at night. While certainly a noisy measure that does not capture economic prosperity in its entirety, it nonetheless is a good proxy to the extent income per capita correlates with population density, urban infrastructure and industrial activity.

In light of previous results on contemporary population density and urbanization rates, one would also expect to see a positive relationship between historical minority presence and luminosity once potentially confounding factors are accounted for. While the descriptive maps in Figure 4 did not reveal much about the conditional nature of these relationships, the evidence in Table 4 corroborates our earlier findings about contemporary population density and urbanization. Both Armenian and Greek shares are highly significant and positive predictors of modern economic development in 2000. Raising the share of Armenian population from the 10th to the 90th percentile of its cross-district distribution is associated with an increase in average luminosity by 24.8 percent at the sample mean (column 8 ). This magnitude is economically meaningful. Back of the envelope calculations based on the unconditional relationship between gross regional product per capita and average luminosity across Turkish provinces (shown in Figure 5) roughly suggest that, conditional on all baseline controls, a modern province with a historical Armenian share of 20 percent (90th percentile) is estimated to have 11 percent higher gross regional product per capita in 2000 than a province with no historical Armenian presence (10th percentile). At the average province income, this effect corresponds to about $\$ 260$ per capita. Similar to population density regressions, the estimates for Armenian presence are sensitive to the omission of regional and geographic characteristics, possibly reflecting the downward bias due to negative selection. We are also able to identify a rather stable Armenian effect based on within subregion or within province variation. This perhaps reflects the local nature of the influence of Armenian presence on regional development.

The estimated relationship between Greek share and mean luminosity is also positive and significant at the 1 percent level. The point estimate is similar in magnitude to that of Armenian population share (see our baseline specification in column (8)). A move from the 10th to the 
TABLE 4: Historical Minority Shares and Average Luminosity in 2000

\begin{tabular}{|c|c|c|c|c|c|c|c|c|c|}
\hline & $\begin{array}{l}(1) \\
\text { OLS }\end{array}$ & $\begin{array}{c}(2) \\
\text { OLS }\end{array}$ & $\begin{array}{l}(3) \\
\text { OLS }\end{array}$ & $\begin{array}{c}(4) \\
\text { OLS }\end{array}$ & $\begin{array}{c}(5) \\
\text { OLS }\end{array}$ & $\begin{array}{c}(6) \\
\text { OLS }\end{array}$ & $\begin{array}{l}7) \\
\text { OLS }\end{array}$ & $\begin{array}{c}8) \\
\text { OLS }\end{array}$ & $\begin{array}{c}9) \\
\text { OLS }\end{array}$ \\
\hline & \multicolumn{9}{|c|}{ Log(Average Luminosity in 2000) } \\
\hline Armenian population share, $1881-1893$ & $\begin{array}{c}0.961^{* *} \\
{[0.378]}\end{array}$ & $\begin{array}{c}1.334^{* * *} \\
{[0.464]}\end{array}$ & $\begin{array}{c}1.532^{* * *} \\
{[0.404]}\end{array}$ & $\begin{array}{c}1.462^{* * *} \\
{[0.489]}\end{array}$ & $\begin{array}{c}1.518^{* * *} \\
{[0.419]}\end{array}$ & $\begin{array}{c}1.416^{* * *} \\
{[0.393]}\end{array}$ & $\begin{array}{c}1.406^{* * *} \\
{[0.357]}\end{array}$ & $\begin{array}{c}1.250^{* * *} \\
{[0.372]}\end{array}$ & $\begin{array}{c}1.242^{* * *} \\
{[0.362]}\end{array}$ \\
\hline Greek population share, 1881-1893 & $\begin{array}{c}1.648^{* * *} \\
{[0.347]}\end{array}$ & $\begin{array}{c}1.791^{* * *} \\
{[0.340]}\end{array}$ & $\begin{array}{c}1.825^{* * *} \\
{[0.342]}\end{array}$ & $\begin{array}{c}1.355^{* * *} \\
{[0.303]}\end{array}$ & $\begin{array}{c}1.126^{* * *} \\
{[0.299]}\end{array}$ & $\begin{array}{c}1.099^{* * *} \\
{[0.306]}\end{array}$ & $\begin{array}{c}1.447^{* * *} \\
{[0.295]}\end{array}$ & $\begin{array}{c}1.241^{* * *} \\
{[0.296]}\end{array}$ & $\begin{array}{c}0.694^{* * *} \\
{[0.218]}\end{array}$ \\
\hline Log(Population density, 1927) & $\begin{array}{c}0.715^{* * *} \\
{[0.086]}\end{array}$ & $\begin{array}{c}0.801^{* * * *} \\
{[0.088]}\end{array}$ & $\begin{array}{c}0.818^{* * *} \\
{[0.084]}\end{array}$ & $\begin{array}{c}0.664^{* * *} \\
{[0.089]}\end{array}$ & $\begin{array}{c}0.649^{* * * *} \\
{[0.083]}\end{array}$ & $\begin{array}{c}0.663^{* * * *} \\
{[0.082]}\end{array}$ & $\begin{array}{c}0.678^{* * *} \\
{[0.079]}\end{array}$ & $\begin{array}{c}0.678^{* * *} \\
{[0.084]}\end{array}$ & $\begin{array}{c}0.683^{* * *} \\
{[0.085]}\end{array}$ \\
\hline $\begin{array}{l}\text { Effect of increasing Armenian share } \\
\text { from the } 10 \text {-th to the } 90 \text {-th percentile }\end{array}$ & $\begin{array}{c}19.122^{* *} \\
{[7.527]}\end{array}$ & $\begin{array}{c}26.546^{* * *} \\
{[9.230]}\end{array}$ & $\begin{array}{c}30.484^{* * *} \\
{[8.030]}\end{array}$ & $\begin{array}{c}29.086^{* * *} \\
{[9.721]}\end{array}$ & $\begin{array}{c}30.214^{* * *} \\
{[8.335]}\end{array}$ & $\begin{array}{c}28.182^{* * *} \\
{[7.813]}\end{array}$ & $\begin{array}{c}27.979^{* * *} \\
{[7.097]}\end{array}$ & $\begin{array}{c}24.874^{* * *} \\
{[7.412]}\end{array}$ & $\begin{array}{c}24.710^{* * *} \\
{[7.195]}\end{array}$ \\
\hline $\begin{array}{l}\text { Effect of increasing Greek share } \\
\text { from the } 10 \text {-th to the } 90 \text {-th percentile }\end{array}$ & $\begin{array}{c}42.487^{* * *} \\
{[8.943]}\end{array}$ & $\begin{array}{c}46.170^{* * *} \\
{[8.773]}\end{array}$ & $\begin{array}{c}47.036^{* * *} \\
{[8.816]}\end{array}$ & $\begin{array}{c}34.918^{* * *} \\
{[7.818]}\end{array}$ & $\begin{array}{c}29.024^{* * *} \\
{[7.712]}\end{array}$ & $\begin{array}{c}28.326^{* * *} \\
{[7.895]}\end{array}$ & $\begin{array}{c}37.287^{* * *} \\
{[7.598]}\end{array}$ & $\begin{array}{c}31.995^{* * *} \\
{[7.622]}\end{array}$ & $\begin{array}{c}17.884^{* * *} \\
{[5.621]}\end{array}$ \\
\hline Observations & 757 & 757 & 757 & 757 & 757 & 757 & 757 & 757 & 757 \\
\hline Adjusted R-squared & 0.289 & 0.321 & 0.322 & 0.433 & 0.458 & 0.460 & 0.497 & 0.513 & 0.596 \\
\hline $\begin{array}{l}\text { Longitude \& Latitude } \\
\text { Mean \& std. of elevation } \\
\text { Lake, sea and major rivers } \\
\text { Temperature \& Precipitation } \\
\text { Suitability to cultivation } \\
\text { Modern region dummies } \\
\text { Modern subregion dummies } \\
\text { Modern province dummies }\end{array}$ & & $\checkmark$ & $\checkmark$ & $\checkmark$ & $\begin{array}{l}\checkmark \\
\checkmark\end{array}$ & $\begin{array}{l}\checkmark \\
\checkmark \\
\checkmark\end{array}$ & $\begin{array}{l}\checkmark \\
\checkmark \\
\checkmark \\
\checkmark \\
\checkmark \\
\checkmark\end{array}$ & $\begin{array}{l}\checkmark \\
\checkmark \\
\checkmark \\
\checkmark \\
\checkmark\end{array}$ & $\begin{array}{l}\checkmark \\
\checkmark \\
\checkmark \\
\checkmark\end{array}$ \\
\hline
\end{tabular}

Notes: This table presents results from the regressions of Log Average Luminosity in 2000 on historical minority shares controlling for past population density, geographical variables, region, subregion or province fixed effects. The estimated effect associated with increasing minority shares from the tenth to the ninetieth percentile of their respective cross-district distributions is expressed in terms of $\%$ change in the level of average luminosity in district. Robust standard errors, clustered at the modern Turkish province (il) level, are reported in square brackets. *** denotes statistical significance at the 1 percent level, $*^{*}$ at the 5 percent level, and ${ }^{*}$ at the 10 percent level.

90th percentile in the population distribution implies an increase in luminosity by 32 percent. Translating this magnitude into regional income, we can roughly conclude that, conditional on baseline controls, a modern province with a historical Greek share of 26 percent (90th percentile) is estimated to have more than 14 percent higher gross regional product per capita in 2000 than a province with no historical Greek presence (10th percentile). At the average province income, this effect corresponds to more than $\$ 335$ per capita. ${ }^{54}$

In Figure 8 we provide the residual scatter plots describing the partial correlations between minority shares and average luminosity. Both plots are based on the baseline model in column (8) of Table 4 and they suggest that the associations we report are not driven by influential outliers.

\footnotetext{
${ }^{54}$ We also show that our results are qualitatively unaffected when we use a larger sample that includes the regions where the Ottoman census was incomplete. Online Appendix Table S.1 replicates luminosity regression results using estimated figures for uncounted populations.
} 

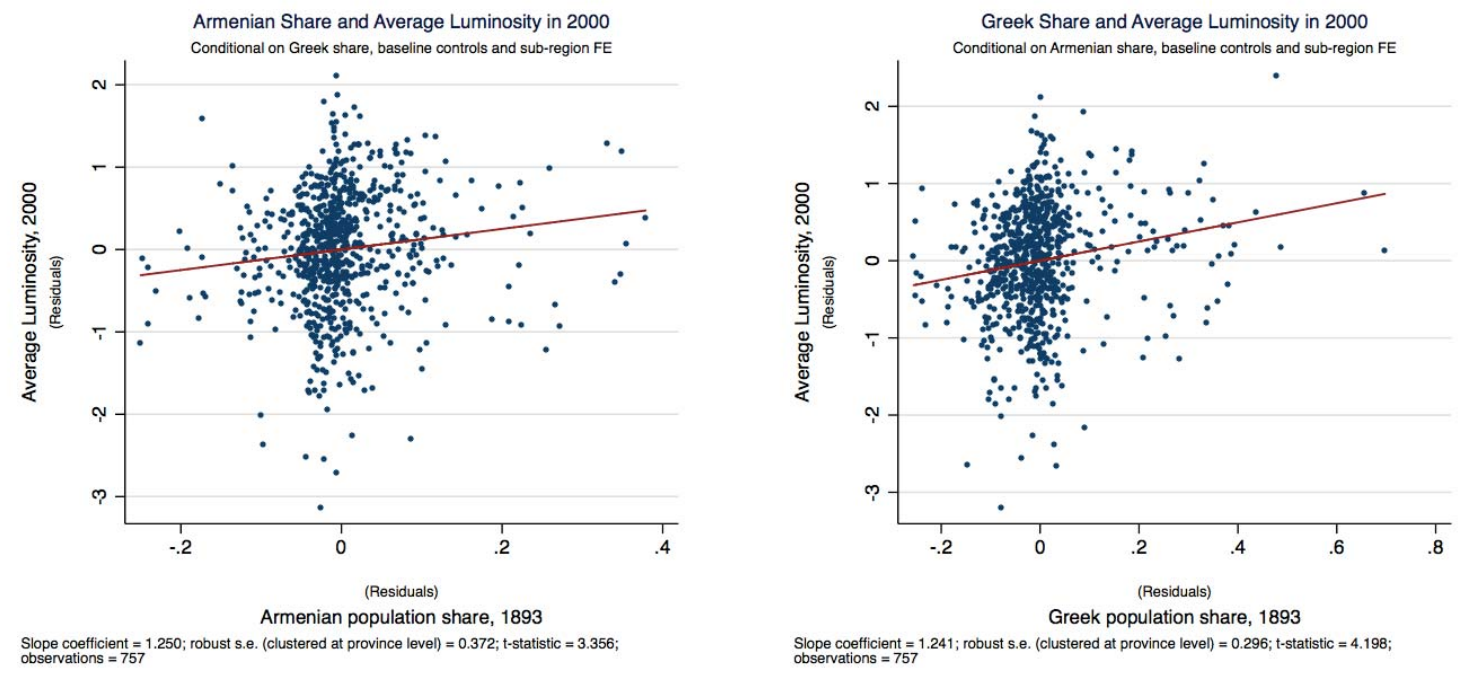

Figure 8: Historical minority shares and Average Luminosity in 2000

\subsubsection{Robustness Analyses of Minority Legacy}

In this section we perform several robustness checks to demonstrate that the significant OLS results we presented in the previous section are not simply due to the omission of potential determinants of economic prosperity or selection of minorities in the first place to areas with greater economic potential.

\subsubsection{Threats to Identification}

In this section, we discuss threats to identification and alternative methods to address potential endogeneity.

First obvious threat to the identification of the effect of minority legacy on long-term development is the omission of potential determinants of economic prosperity. We try our best to control for a comprehensive list of geographic and climatic variables as well as past population density, subregion or province fixed effects, and historical determinants of development (see below).

A second concern might be the potential selection of minorities into regions with greater economic potential, which would bias our baseline OLS results. Given the fact that Armenians and Greeks settled in Anatolia many millennia ago, if there was any selection driven by economic potential it should be largely based on the main economic activity of the time, agriculture. In our baseline specification, we control for an exhaustive list of geographic and climatic variables 
that would predict agricultural activity. The implied assumption here is that, once conditioned on the predictors of agricultural activity, ancient settlement patterns are unlikely to be selective on unobserved drivers of modern economic activity. Given the distribution of minorities across Anatolia, this mechanism should hold more strongly for Armenians than for Greeks. To alleviate such concerns about endogeneity, in addition to baseline controls, we account for potential historical correlates of development (to be discussed below). Furthermore, we use various matching estimators to compare locations with high and low minority presence that are similar with respect to exogenous geographical characteristics.

Similarly, one could argue that minority presence simply captures unobservable factors that drive development. Although that may very well be the case, our analysis in the next section suggests that selection on unobservables needs to be substantially larger than selection on observables to explain away our coefficient estimates. ${ }^{55}$ Moreover, our instrumental variable analysis (shown below) also supports our findings to the extent that ancient settlement patterns of minorities are persistent but unlikely to be selective on unobserved drivers of modern growth.

Another source of potential bias to our results would be the penetration into and the distribution across Anatolia of Muslim peoples. However, once Muslims start spreading across Anatolia they also had incentives to locate into more lucrative areas with greater economic potential. As a consequence, both the concentration of the population of non-Muslims and their economic activities should be diluted over time as the Muslim penetration extends. Therefore, Muslim/Turkish conquests of Anatolia would work against our findings and might bias the results in opposite direction.

One other issue is the selective conversion of non-Muslims to Islam throughout history. Poll tax and other taxes levied on non-Muslims might have induced conversions from Christianity to Islam by socio-economic status. ${ }^{56}$ If so, one would expect to observe higher minority shares at the end of the 19th century particularly in those regions that were historically home to richer strata of the Armenian and Greek communities. This might explain why these communities were on average wealthier and more educated than Muslims. On the other hand, we know that in the Ottoman

\footnotetext{
${ }^{55}$ Altonji et al. (2005) ratios are reasonably large: 19.52 for Armenians and 4.20 for Greeks. See more details below.

${ }^{56}$ For example, Saleh et al. (2015) argues that Egypt's conversion from Coptic Christianity to Islam was largely characterized by self-selection-on-socioeconomic-status: Those Copts that did not convert despite a regressive taxon-religion were differentially better-off.
} 
context, conversion to Islam was quite common among the wealthiest and highly-educated nonMuslims, because it was deemed necessary to rise up in the upper ranks of the Ottoman bureaucracy and the palace. ${ }^{57}$ Ultimately, our IV and matching estimates aim to overcome this and other types of endogeneity we previously discussed. As long as our instruments are orthogonal to the factors of modern economic activity, our results should hold. ${ }^{58}$

\subsubsection{Selection on Observables and Unobservables}

In this section, following the method developed by Altonji et al. (2005), we exploit the idea that the degree of selection on unobserved variables can be inferred from the degree of selection on observed variables. This method allows us to assess how large the selection bias from unobserved heterogeneity should be, relative to the bias from selection on observables, to fully explain away the entire coefficients on our variables of interest. In particular, we examine the absolute magnitude of the ratio, $\hat{\alpha}^{F} /\left(\hat{\alpha}^{R}-\hat{\alpha}^{F}\right)$, where $\hat{\alpha}^{R}$ is our estimate from a restricted model and $\hat{\alpha}^{F}$ is the estimate from another specification (the full specification) that nests the restricted model. Intuitively, a high absolute value for this ratio means that the estimated coefficients on Armenian and Greek shares cannot be completely attributed to omitted-variable bias unless the amount of selection on unobservables is much larger than that on observables. In Table 5, we present these ratios both for Armenian and Greek shares under several pairs of restricted and full specifications.

TABLE 5: Assessing potential selection bias from unobserved heterogeneity

\begin{tabular}{ccc}
\hline \hline & \multicolumn{2}{c}{$\left|\hat{\alpha}^{F} /\left(\hat{\alpha}^{R}-\hat{\alpha}^{F}\right)\right|$ for } \\
& Armenian share & Greek share \\
\cline { 2 - 3 } Table 4 & & \\
R: (2), F: (3) & 7.73 & 53.67 \\
R: (2), F: (4) & 11.42 & 3.10 \\
R: (2), F: (5) & 8.25 & 1.69 \\
R: (2), F: (6) & 17.26 & 1.58 \\
R: (2), F: (7) & 19.52 & 4.20 \\
\hline \hline
\end{tabular}

\footnotetext{
${ }^{57}$ One example of this type of conversion is the famous architect Sinan. Sinan the Grand Architect was born an Armenian Christian but later on converted to Islam and became the grand architect of the Ottoman Empire.

${ }^{58}$ Relatedly, at the time of the expulsions and killings around 1915, conversion to Islam was not an effective survival strategy. There is evidence from wired orders sent by the Ministry of Interior to provinces and governorships stating that "Armenians who converted to Islam should not be exempt from relocations" (Devlet Arşivleri, 1995).
} 
We assess the strength of potential selection on unobservables for our baseline table (Table 4) where we successively add controls for various geographical features and climatic conditions. We fix column (2) as our restricted model and retain region dummies in all models. Depending on what specification we compare, the resulting ratios range between 7.73 and 19.52 for Armenian share, and between 1.58 and 53.67 for Greek share. By looking at the relative change in coefficient estimates from the most restricted (column (2)) to the least restricted model (column (7)), we conclude that selection on unobservables would have to be at least 19.52 times larger than selection on observables, in order for our estimated coefficient on Armenian share to be entirely attributable to selection on unobservables. The corresponding figure is 4.20 for Greek share.

\subsubsection{Sensitivity to Historical Correlates of Development}

In this section, we evaluate the robustness of our results to omitted (but possibly endogenous) correlates of historical and contemporary development. All robustness analyses for the effect of minority shares on luminosity are presented in Table 6. First column simply replicates the baseline estimates shown in column (8) of Table 4. In subsequent columns, we conduct various robustness checks to be discussed below.

Access to Railroads and Ports. One concern is that regions with greater access to railroad or major port infrastructure in the past might have developed earlier than others (e.g. (Donaldson and Hornbeck, 2016; Jedwab et al., 2015)). Clearly, railroad construction is not random, and it might well be an outcome of the economic activity historically generated by minorities. Moreover, the locations on the railroad network and the exact path it follows depend on economic potential of the waypoints it connects as well as the topography of the region. This is as much true for contemporary rail networks as for the railroads in the past. However, since we do not want to control for any indirect causal effect of minorities on current development, we attempt to control for access to railroads as further in the past as possible. Using maps of the historical rail network around 1910, we calculate distances of districts to the nearest railroad. Similarly, to measure access to sea trade, we compute distances of districts to the nearest major 19th century port. ${ }^{59}$

When we control for these two variables in column (2), distance to railroads in 1910 has a significantly negative association with economic development in 2000, whereas distance to major

\footnotetext{
${ }^{59}$ These major ports are situated in Istanbul, Trabzon, Mersin, Iskenderun, Samsun and Izmir.
} 
ports is insignificant. Reassuringly, the coefficients on Armenian and Greek population shares remain significant. However, the estimated magnitudes are somewhat smaller compared to the baseline results in column (1). A move from the 10th to the 90th percentile of the Armenian population distribution corresponds to an increase in average luminosity by 20.5 percent instead of 25 percent. Results are qualitatively similar for Greeks. The marginal effects corresponding to a 10th-to-90th percentile move becomes weaker and is reduced by 4.5 percentage points, from 32 down to 27.5 percent.

The reduction in the minority share coefficients reflects the fact that, other things equal, both the Armenians and Greeks were systematically more likely to live in districts with easier access to railroads and major ports. However, it is important to note that hundreds of years of minority presence and their economic activity might have created the conditions ripe for economic infrastructure investments.

TABle 6: Minority Shares and Average Luminosity, Robustness to Historical Correlates of Economic Development

\begin{tabular}{|c|c|c|c|c|c|c|c|c|}
\hline & $\begin{array}{l}(1) \\
\text { OLS }\end{array}$ & $\begin{array}{c}(2) \\
\text { OLS }\end{array}$ & $\begin{array}{l}(3) \\
\text { OLS }\end{array}$ & $\begin{array}{c}(4) \\
\text { OLS }\end{array}$ & $\begin{array}{c}(5) \\
\text { OLS }\end{array}$ & $\begin{array}{c}(6) \\
\text { OLS }\end{array}$ & $\begin{array}{c}(7) \\
\text { OLS }\end{array}$ & $\begin{array}{c}(8) \\
\text { OLS }\end{array}$ \\
\hline & \multicolumn{8}{|c|}{ Log(Average Luminosity in 2000) } \\
\hline Armenian population share, $1881-1893$ & $\begin{array}{c}1.250^{* * *} \\
{[0.372]}\end{array}$ & $\begin{array}{c}1.033^{* * *} \\
{[0.347]}\end{array}$ & $\begin{array}{c}1.240^{* * *} \\
{[0.371]}\end{array}$ & $\begin{array}{c}1.237^{* * *} \\
{[0.351]}\end{array}$ & $\begin{array}{c}1.103^{* * *} \\
{[0.385]}\end{array}$ & $\begin{array}{c}1.075^{* * *} \\
{[0.355]}\end{array}$ & $\begin{array}{c}0.846^{* *} \\
{[0.339]}\end{array}$ & $\begin{array}{l}0.601^{*} \\
{[0.317}\end{array}$ \\
\hline Greek population share, 1881-1893 & $\begin{array}{c}1.241^{* * *} \\
{[0.296]}\end{array}$ & $\begin{array}{c}1.067^{* * *} \\
{[0.281]}\end{array}$ & $\begin{array}{c}1.238^{* * *} \\
{[0.295]}\end{array}$ & $\begin{array}{c}1.021^{* * *} \\
{[0.267]}\end{array}$ & $\begin{array}{c}1.179^{* * *} \\
{[0.312]}\end{array}$ & $\begin{array}{c}1.123^{* * *} \\
{[0.253]}\end{array}$ & $\begin{array}{c}0.797^{* * *} \\
{[0.270]}\end{array}$ & $\begin{array}{c}0.742^{* *} \\
{[0.284]}\end{array}$ \\
\hline Log(Population density, 1927) & $\begin{array}{c}0.678^{* * *} \\
{[0.084]}\end{array}$ & $\begin{array}{c}0.577^{* * *} \\
{[0.085]}\end{array}$ & $\begin{array}{c}0.667^{* * *} \\
{[0.080]}\end{array}$ & $\begin{array}{c}0.689^{* * *} \\
{[0.083]}\end{array}$ & $\begin{array}{c}0.667^{* * *} \\
{[0.081]}\end{array}$ & $\begin{array}{c}0.685^{* * *} \\
{[0.084]}\end{array}$ & $\begin{array}{c}0.474^{* * *} \\
{[0.065]}\end{array}$ & $\begin{array}{c}0.453^{* * *} \\
{[0.068]}\end{array}$ \\
\hline Effect of increasing Armenian share & $24.874^{* * *}$ & $20.565^{* * *}$ & $24.677^{* * *}$ & $24.612^{* * *}$ & $21.942^{* * *}$ & $21.386^{* * *}$ & $16.827^{* *}$ & $11.950^{*}$ \\
\hline from the 10 -th to the 90 -th percentile & {$[7.412]$} & {$[6.899]$} & {$[7.390]$} & [6.989] & {$[7.660]$} & {$[7.073]$} & {$[6.752]$} & {$[6.307]$} \\
\hline $\begin{array}{l}\text { Effect of increasing Greek share } \\
\text { from the } 10 \text {-th to the } 90 \text {-th percentile }\end{array}$ & $\begin{array}{l}31.995^{* * *} \\
{[7.622]}\end{array}$ & $\begin{array}{c}27.506^{* * *} \\
{[7.235]}\end{array}$ & $\begin{array}{c}31.902^{* * *} \\
{[7.603]}\end{array}$ & $\begin{array}{c}26.312^{* * *} \\
6.895]\end{array}$ & $\begin{array}{c}30.385^{* * *} \\
{[8.047]}\end{array}$ & $\begin{array}{c}28.947^{* * *} \\
{[6.522]}\end{array}$ & $\begin{array}{c}20.542^{* * *} \\
6.962]\end{array}$ & $\begin{array}{c}19.124^{* *} \\
{[7.326]}\end{array}$ \\
\hline Observations & 757 & 757 & 757 & 757 & 757 & 757 & 757 & 757 \\
\hline Adjusted R-squared & 0.513 & 0.539 & 0.515 & 0.518 & 0.515 & 0.523 & 0.587 & 0.600 \\
\hline Baseline controls & $\checkmark$ & $\checkmark$ & $\checkmark$ & $\checkmark$ & $\checkmark$ & $\checkmark$ & $\checkmark$ & $\checkmark$ \\
\hline Distances to Railroad in 1910 \& Major 19th century port & & $\checkmark$ & & & & & & $\checkmark$ \\
\hline Distance to war front (1919-1922) & & & $\checkmark$ & & & & & $\checkmark$ \\
\hline WW1 casualties in province & & & $\checkmark$ & & & & & $\checkmark$ \\
\hline Share of settled immigrants (1921-1929) & & & & $\checkmark$ & & & & $\checkmark$ \\
\hline Share of Kurdish speakers (1927) in province & & & & $\checkmark$ & & & & $\checkmark$ \\
\hline In central kaza or sancak & & & & & $\checkmark$ & & & $\checkmark$ \\
\hline Distances to Istanbul \& nearest national border & & & & & & $\checkmark$ & & $\checkmark$ \\
\hline Distance to Anatolian Silk Road & & & & & & & $\checkmark$ & $\checkmark$ \\
\hline Distance to Ottoman Trade Routes & & & & & & & $\checkmark$ & $\checkmark$ \\
\hline Modern subregion dummies & $\checkmark$ & $\checkmark$ & $\checkmark$ & $\checkmark$ & $\checkmark$ & $\checkmark$ & $\checkmark$ & $\checkmark$ \\
\hline
\end{tabular}

Notes: This table presents results from the regressions of Log Average Luminosity in 2000 on historical minority shares controlling for past population density, geographical variables, historical correlates of economic development, and subregion fixed effects. The estimated effect
associated with increasing minority shares from the tenth to the ninetieth percentile of their respective cross-district distributions is expressed in terms of \% change in the level of average luminosity in district. Robust standard errors, clustered at the modern Turkish province (il) level, are terms of $\%$ change in the level of average luminosity in district. Robust standard errors, clustered at the modern Turkish province $(i l)$ level, are
reported in square brackets. ${ }^{* *}$ denotes statistical significance at the 1 percent level, $* *$ at the 5 percent level, and $*$ at the 10 percent level. 
Exposure to War. Late 19th and early 20th centuries were a period of constant warfare for the Ottoman Empire. Ottoman Empire took part in the WWI alongside the Central Powers of Germany and Austria-Hungary. Following the defeats in several fronts (except in the Gallipoli campaign) the Ottoman Empire disintegrated. Much of its non-Anatolian territory came under the control of Allied powers as protectorates. Meanwhile, in the Turkish core of Anatolia, that was not occupied by the Allied powers, the Turkish National Movement mobilized a large scale resistance to foreign occupation, culminating in the Turkish War of Independence (1919-1923). This war ended with the victory of the Turkish National Movement and led to the signing of the Treaty of Lausanne in July 1923, by which the Republic of Turkey was recognized as a sovereign state and the successor to the Ottoman Empire.

Both the WWI and the War of Independence had devastating consequences for the peoples of Anatolia both in terms of human casualties and material destruction. Therefore, one potential concern is the possibility that regions that were more heavily affected by the destructive forces of war might have fallen behind other regions on their way to recovery. Although destruction of physical capital and infrastructure is unlikely to have a direct negative effect that would persist well into year 2000 (Davis and Weinstein, 2002; Miguel and Roland, 2011), the loss of human capital due to battle-related deaths and migrations spurred by warfare might have left a trace on regional development trajectories.

We use two measures of war exposure. The first one is the number of Ottoman soldiers who died in battle during the WWI. Using information on soldiers' birth province, we assign to each district the corresponding number of casualties in the province containing that district. The second variable is the distance to the nearest war front in the Turkish War of Independence. Of course, both variables might be endogenous to historical correlates of regional development. Soldier participation in WWI could partly be determined by distance to battle fronts, geographic isolation as well as the capacity of the Ottoman government to recruit soldiers and punish defectors. Similarly, location of war fronts may depend on several logistical factors including local support, resource availability as well as the strategic priorities of occupying forces.

Column (3) in Table 6 reports the results conditional on our war exposure measures. Conditional on our exogenous baseline controls, distance to war fronts in 1919-1922 and WWI 
casualties have a positive, albeit insignificant, relationship with average luminosity in $2000 .{ }^{60}$ Importantly, the Armenian and Greek share coefficients remain extremely stable compared to the baseline model in column (1).

Settlement of Immigrants and Kurdish Presence. Late 19th and early 20th centuries witnessed the decline and the eventual collapse of the Ottoman Empire. This period was inevitably also a period of involuntary migrations. Many Turkish (Turkic) and Muslim peoples from the Balkans, Caucasus, Crimea (Crimean Tatar diaspora) and Crete were forced to leave their homes and settle in present-day Turkey.

Over the course of the Greco-Turkish War (1919-1922), the majority of the Ottoman Greeks already fled along with the retreating Greek Army. The population exchange between Turkey and Greece in 1923 simply formalized an ongoing de facto expulsion of the Greeks from Anatolia and the influx of about 350,000 Muslims from Greece into Turkey. Many of the Muslim immigrants were resettled by the government into locations once inhabited by Armenians and Greeks. This poses a challenge in terms of disentangling the long-run impact of minorities on current outcomes from the potential effect of incoming Muslim migrants that replaced them. One way to partially address this issue is to explicitly account for the regional distribution of immigrants who settled after the departure of Armenians and Greeks. ${ }^{61}$

We have information on the number of immigrants that settled in Turkish provinces over the period 1921-1929. To construct our immigration measure, we take the cumulative number of immigrants to each province during 1921-1929 divide it by the province population in 1927 .

Historically, Kurdish population was largely nomadic pastoralists and was highly concentrated in the eastern and the southeastern part of Anatolia in the areas inhabited by Armenians. Even after accounting for region fixed effects and geographical factors, Kurdish presence may still

\footnotetext{
${ }^{60}$ Coefficients on these variables are not shown for the sake of brevity.

${ }^{61}$ There were two other major waves of immigration of Muslim populations into what is now the territory of the Turkish Republic prior to the Armenian deportations of 1915-1916 and the Greek-Turkish population exchange. The first wave was triggered by the Russo-Turkish War (1877-1878) which was fought between the Ottoman Empire and the Eastern Orthodox coalition led by the Russian Empire and composed of several Balkan countries. These Muslim migrants must have been registered in the historical Ottoman census we use. The second wave came with the first Balkan War (1912-1913) between the Ottoman Empire and the Balkan League (Serbia, Greece, Montenegro and Bulgaria). Ottoman Empire experienced a heavy defeat resulting in the loss of almost all of its remaining European territory. Muslims fleeing from the conflict and the assimilation policies of the newly independent Balkan nations took refuge in the Ottoman land. We do not have data to take into account this set of Muslim migrants.
} 
influence directly or indirectly some contemporary or historical determinants of local development. 62

In column (4) of Table 6, we control for the number of immigrants between 1921-1929 and the number of Kurdish speakers in 1927 as a share of total 1927 population. ${ }^{63}$ Presence of immigrants significantly predicts mean luminosity in year 2000, lending suggestive evidence for the conventional wisdom that, in the long-run, these Muslim immigrants had a positive contribution to the economic development of the Turkish Republic. On the other hand, the presence of Kurdish speakers has no significant effect. Reassuringly, both Armenian and Greek population shares remain significant at the 1 percent level. Also, comparing columns (1) and (4), the estimated magnitudes for minority population shares appear stable.

Historical Regional Centers. One may question whether our results are biased due to a systematic self-selection of Armenian and Greek communities into historically more central and urbanized locations where trade and manufacturing were relatively more important. Indeed, such systematic selection is likely and is consistent with both historical evidence and our own regression analysis of settlement patterns (not shown here). While today some of these regional centers of economic activity might have lost their previous significance, many of them plausibly remained as important economic centers and retained their economic lead vis-a-vis other locations in their near periphery.

To mitigate this problem, in column (5) of Table 6 we use a dummy variable for modern districts that were assigned to the central kaza (merkez kaza) of a given Ottoman sancak (the administrative unit that is one level above kaza). The coefficient on this indicator is positive and barely significant, possibly because the baseline controls already account for the main characteristics that determined the location of these centers. Population shares of Armenians and Greeks remain highly significant. The predicted changes in luminosity in response to higher minority presence

\footnotetext{
${ }^{62}$ Since the mid-1980s, predominantly Kurdish areas have been a scene for frequent fighting between the Kurdish armed insurgents and the Turkish military. Localities affected by the civil conflict received low levels of private investment, had lower levels of schooling but possibly benefited more from generous government transfers compared to otherwise similar locations.

${ }^{63}$ Results are qualitatively similar if instead of the immigrant flow at the province level we control -as a proxy for immigrant concentration- for the district-level share of 1927 population who were born in Turkey and in other countries like Albania, Greece and Romania that were among the major senders of Muslim immigrants during the late 19 th and the early 20th century.
} 
are somewhat smaller in percentage terms, but they do not statistically differ from the baseline magnitudes.

Distance to Istanbul and to the National Borders. Proximity to Istanbul as the historical capital of the Ottoman Empire and the most important economic center of Turkey (both now and in the past) is a strong predictor of economic activity today. Historically, the forces of attraction towards this economic hub were almost certainly stronger for Greeks and Armenians than it was for Muslims -relative to their overall representation in the Ottoman population.

In addition, other things equal, proximity to national borders may influence the degree and types of economic activity. And, we would not like to attribute such a largely contemporary effect to a systematic or a purely coincidental clustering of minority populations close to borders.

To address these concerns, in column (6), we control for distances to Istanbul and to the nearest national border. As expected, luminosity decreases with the distance from Istanbul, while distance from borders has no significant effect. In line with the above positive selection story, point estimates for both minority share variables somewhat decline vis-a-vis the baseline model in column (1), though these changes are not large and not statistically significant.

Anatolian Silk Road and Ottoman Trade Routes. One may think that minorities might have selected into areas with greater trading potential and benefited from this disproportionately compared to the Muslims. Moreover, locations with greater trading advantage might have developed independently of minorities' contribution to the economic activity, and such a positive selection story might explain away the economic legacy of minorities. However, it is crucial to recall that Armenian and Greek minorities were natives of Anatolia. They have inhabited the area and contributed to its economic development for millennia. Therefore, Armenian and Greek minorities might be, at least partially, responsible for the development of trade links in the first place. Moreover, the Turkic tribes, after having arrived in Anatolia in the 11th century, together with other Muslim peoples have scattered across Anatolia over many centuries, and there is no reason to think that Muslim populations would not locate to regions with a trading potential.

Nevertheless, to explicitly take into account such concerns, in column (7) of Table 6 we control for the distance to the Anatolian Silk Road as well as the distance to the Ottoman trade routes. These two variables are certainly important predictors of economic development. 
Luminosity significantly decreases with both variables. Although the impact of minority shares on luminosity shows the largest reduction compared to the baseline specification, both Armenian and Greek coefficients are still highly significant. The effect of a move from the 10th to the 90th percentile of the Armenian distribution is a 17 percent increase in luminosity, while this same effect for Greeks corresponds to 20.5 percent.

Finally, in the last column of Table 6, all robustness controls together with subregion fixed effects are added simultaneously to the baseline model. In column (8), the results from the full specification with subregion fixed effects suggest that even in the presence of a fairly exhaustive list of potential confounders, our main conclusions about the minority legacy remain unchanged. Both Greek and Armenian population shares are positive predictors of long-run economic development. While Armenian share is significant at the 10 percent level, Greek share is significant at the 5 percent level. The estimated marginal effects under this very stringent specification are lower than those reported in column (1). Thus, we consider the magnitudes reported in column (8) as the respective lower bounds for the influence of historical Armenian and Greek presence on regional development. According to these lower bound estimates, a region that was at the 90th percentile of the Armenian population share distribution prior to the deportations had, on average, 12 percent higher luminosity in year 2000 than an otherwise identical region without Armenians. The corresponding difference due to Greek presence is about 19 percent.

In general terms, the main concern about the identification of the minority legacy is that the positive relation between historical minority presence and modern economic development might be partly driven by the persistence of initial conditions that are not necessarily a legacy of minority presence but rather some 'deep' attributes on which there was differential self-selection across ethno-religious groups. In this section, we have attempted to address the most likely problems related to self-selection. Therefore, the results presented in Table 6 strengthen our confidence in the robustness of the positive legacy of Greeks and Armenians. Nonetheless, our results should be interpreted with caution since we cannot completely rule out the possibility that selection occurred in the distant past on unobserved factors which still remain important for regional variation in development.

\subsubsection{Matching Estimates}


In this section, we provide results from covariate and propensity score matching analyses. Matching estimators offer an appropriate comparison across treatment and control districts. Better counter-factual control districts for the treated ones help us mitigate endogeneity concerns to the extent that initial selection was based on the exogenous characteristics of a location when the minorities first moved in millennia ago.

To that end, we first construct Armenian and Greek treatment dummies. Armenian treatment indicator takes the value 1 if the share of Armenians in that district is larger than the median Armenian share across districts; otherwise 0. We create a Greek treatment indicator likewise. ${ }^{64}$

In the pre-treatment set of selection variables, only those variables that are unaffected by the treatment itself should be included. ${ }^{65}$ To ensure this, variables should either be fixed over time or measured before treatment. Population density in 1927 does not fit this requirement as it was an outcome of the presence of minorities in the Ottoman Empire. Moreover, given that the economic incentives of the time were driven by agricultural economic activities, geographic and climatic characteristics as well as suitability to cultivation must have influenced selection patterns. Therefore, we carry out our matching exercise based on the exogenous geographic and climatic characteristics of the baseline model, namely, longitude, latitude, elevation, standard deviation of elevation, lake, sea, river dummies, temperature, precipitation, and suitability to cultivation.

We apply a two-sided common support to the propensity score, and restrict the sample to those treatment and control districts with overlapping propensity scores. In addition, we ensure that the balancing property is satisfied throughout. ${ }^{66}$

\footnotetext{
${ }^{64}$ Before we carry out our analysis to obtain the results in Table 7, we filter out subregion fixed effects both from minority shares and luminosity. This provides us with more comparable treatment and control units. In Panel A of the Online Appendix Table S.4, we reproduce the same matching exercise with treatment indicators generated from the median of the raw data without filtering out subregion fixed effects. The results are similar. In addition, in Panel B of the Online Appendix Table S.4, we provide results with another alternative treatment indicator, where treatment is set to 1 for districts with more than $1 \%$ minority share. The results are qualitatively the same.

${ }^{65}$ See Smith and Todd (2005) for a discussion on the choice of pre-treatment selection variables and which variables to include in the matching procedure.

${ }^{66} \mathrm{We}$ ensure that the balancing property is satisfied as follows. We run the propensity score algorithm for the Armenian Treatment indicator and the balancing property is satisfied right away. This could be gauged already from Panel A of Table S.2 in the Online Appendix, where most of the covariates are balanced across treated and control districts. When we run the propensity score algorithm for the Greek Treatment indicator, however, the balancing property does not hold. This could be expected from the poor covariate balance in Panel B of Table S.2. We, then, trim the sample to the propensity score interval of $[0.2,0.8]$ over which the overlap between treatment and control is better as Panel C of Table S.2 indicates. Under this restricted sample balancing property is satisfied. Then, we move on to carry out our matching exercises (Abadie et al., 2004; Becker and Ichino, 2002).
} 
TABLE 7: Minority Presence and Luminosity: Matching Estimates

\begin{tabular}{|c|c|c|c|c|c|c|c|}
\hline & $(1)$ & $2(2)$ & (3) & $(4)$ & (5) & $(6)$ & (7) \\
\hline & & & Covariate Matching & \multicolumn{4}{|c|}{ Propensity Score Matching } \\
\hline & OLS & OLS & Nearest Neighbour & Nearest Neighbour & Radius $(\mathrm{r}=0.05)$ & Kernel $(\mathrm{bw}=0.02)$ & Stratification \\
\hline & \multicolumn{7}{|c|}{ Panel A: Armenian Treatment Estimates (Dep.Var.: Log Average Luminosity in 2000) } \\
\hline Armenian Treatment & 0.302 & 0.298 & 0.348 & 0.292 & 0.328 & 0.316 & 0.304 \\
\hline Armenian Treatment (Bias Adjusted) & - & - & 0.308 & 0.281 & 0.327 & 0.319 & 0.300 \\
\hline Bootstrapped Standard Errors & {$[0.084]^{* * *}$} & {$[0.084]^{* * *}$} & - & {$[0.093]^{* * *}$} & {$[0.070]^{* * *}$} & {$[0.071]^{* * *}$} & {$[0.069]^{* * *}$} \\
\hline Analytical Standard Errors & $(0.084)^{* * *}$ & $(0.085)^{* * *}$ & $(0.079)^{* * *}$ & $(0.091)^{* * *}$ & $(0.072)^{* * *}$ & {$\left[\begin{array}{lll}{[0.011} \\
{[-}\end{array}\right.$} & $(0.068)^{* * *}$ \\
\hline Treatment effect (\%) & 35.3 & 34.7 & 36.1 & 32.4 & 38.7 & 37.6 & 35.0 \\
\hline Treatment Districts & - & - & 372 & 372 & 372 & 372 & 372 \\
\hline Control Districts & - & - & 379 & 201 & 379 & 379 & 379 \\
\hline Common Support & No & Yes & Yes & Yes & Yes & Yes & Yes \\
\hline Balancing Property Satisfied & - & - & - & Yes & Yes & Yes & Yes \\
\hline \multirow[t]{2}{*}{ Number of observations } & 758 & 751 & 751 & 573 & 751 & 751 & 751 \\
\hline & \multicolumn{7}{|c|}{ Panel B: Greek Treatment Estimates (Dep.Var.: Log Average Luminosity in 2000) } \\
\hline Greek Treatment & 0.378 & 0.405 & 0.414 & 0.382 & 0.495 & 0.399 & 0.416 \\
\hline Greek Treatment (Bias Adjusted) & - & - & 0.397 & 0.390 & 0.492 & 0.403 & 0.416 \\
\hline Bootstrapped Standard Errors & {$[0.090]^{* * *}$} & {$[0.077]^{* * *}$} & - & {$[0.094]^{* * *}$} & {$[0.076]^{* * *}$} & {$[0.071]^{* * *}$} & {$[0.072]^{* * *}$} \\
\hline Analytical Standard Errors & $(0.086)^{* * *}$ & $(0.082)^{* * *}$ & $(0.086)^{* * *}$ & $(0.098)^{* * *}$ & $(0.078)^{* * *}$ & - & $(0.073)^{* * *}$ \\
\hline Treatment effect (\%) & 45.9 & 49.9 & 48.7 & 47.7 & 63.6 & 49.6 & 51.6 \\
\hline Treatment Districts & - & - & 279 & 279 & 278 & 279 & 278 \\
\hline Control Districts & - & - & 322 & 152 & 322 & 322 & 323 \\
\hline Common Support & No & Yes & Yes & Yes & Yes & Yes & Yes \\
\hline Balancing Property Satisfied & - & - & - & Yes & Yes & Yes & Yes \\
\hline Number of observations & 758 & 601 & 601 & 431 & 600 & 601 & 601 \\
\hline
\end{tabular}

Notes: This table presents the covariate and propensity score matching estimates of the average treatment effect on the Armenian and Greek treated districts (ATT), in Panels A and B respectively. Armenian and Greek Treatment indicators are equal to 1 for above median shares of respective distributions aft The ba sea, river dummies, temperature, precipitation, and sutabilty to cultivation. To ensure that balancing property is satisfied, we trim the sample for the for small sample bias due to non-exact matches. Nearest neighbor matching with random draw is applied in column (4). The Epanechnikov kernel (bandwidth-0.02) is applied in column (6). Bootstrapped standard errors (1000 replications) are given in brackets, while analytical standard the 1 percent level, $*^{*}$ at the 5 percent level, and ${ }^{*}$ at the 10 percent level.

Table 7 presents the covariate and propensity score matching estimates of the average treatment effect of the Armenian and Greek treated districts (ATT) on luminosity, in Panels A and B respectively. For comparison purposes, columns (1) and (2) show the OLS coefficients of minority treatments both on the entire sample and on the common support, respectively. Remaining columns show results from nearest neighbor covariate matching, ${ }^{67}$ and propensity score matching ${ }^{68}$ with nearest neighbor, radius, kernel or stratification algorithms. ${ }^{69}$

In Panel A, the ATT of the Armenian presence under various matching methods ranges between $32.4 \%$ to $38.7 \%$, always significant at the $1 \%$ level. The positive effect of the Armenian treatment under OLS in columns (1) and (2) is not very different from matching estimates, and

\footnotetext{
${ }^{67}$ See Abadie and Imbens (2006) and Abadie et al. (2004).

${ }^{68}$ See Rosenbaum and Rubin (1983).

${ }^{69}$ Table S.3 in the Online Appendix shows the robustness of the results in Table 7 to alternative propensity score matching methods.
} 
it does not change much when the regression is on the entire sample or on the common support sample.

In Panel B, on the other hand, under different matching methods the ATT of Greek presence increases luminosity by 47.7 to 63.6 percent. Moreover, OLS estimate on the entire sample seems underestimated compared to the coefficient of the regression on the common support.

\subsubsection{Instrumental Variable Analysis}

Lastly, we carry out instrumental variable analysis to further take into account endogeneity concerns. Since models with multiple endogenous variables are hard to identify, and the results can be hard to interpret, we tackle the endogeneity issue for Armenians and Greeks separately. ${ }^{70}$

Armenian IV Estimates. To predict the 19th century distribution of Armenian population across Anatolia, we identify historical capitals of Armenian Kingdoms prior to the Ottoman rule. These capitals were Van (860-590 BC) -first under the Urartian Kingdom then under the Armenian Kingdom of Vaspurakan-, Artashat (176-77 BC, 69-120 AD) of the Kingdom of Armenia, Tigranakert/Silvan (77-69 BC) built by Tigran the Great, the most notable ruler of the Armenian Kingdom, and Sis/Kozan (1198-1375) of the Armenian Kingdom of Cilicia. Figure 9 presents geographical locations of these capitals. These capitals were economic, cultural and administrative centers of attraction for Armenians and offered protection from potential enemies, and therefore, must have shaped the distribution of Armenian population across Anatolia. Thus, to the extent that ancient settlement patterns persisted over time, distance to Armenian capitals should predict Armenian presence in 1893. The closer a location to the capital of an Armenian Kingdom, the more likely it is for the inhabitants of that location to be of Armenian ethnicity.

We exploit the joint predictive power of proximity to these capitals in explaining Armenian presence, and use the logarithm of distances to Armenian Kingdom capitals to instrument the historical share of Armenians in a given district. ${ }^{71}$ Our exclusion restriction assumption is that,

\footnotetext{
${ }^{70}$ In any case, if the instruments satisfy the exclusion restriction, omission of potentially endogenous controls should not bias the IV estimates of the coefficient of interest.

${ }^{71}$ If the mechanisms we suggest above for the predictive power of distance to Armenian kingdom capitals for Armenian share hold, then the relationship between the distance to kingdom capitals and Armenian share should be non-linear, with the slope of the correlation converging to zero. Consistently, log distance to kingdom capitals yield a much better first stage fit than the linear distance measures. For example, in columns (3) and (4) Table 8, log of distance instruments give a first stage F-stat of about 16 and 18, whereas same instruments in linear distances give a first stage F-stat of 3.8 and 0.9 , respectively.
} 


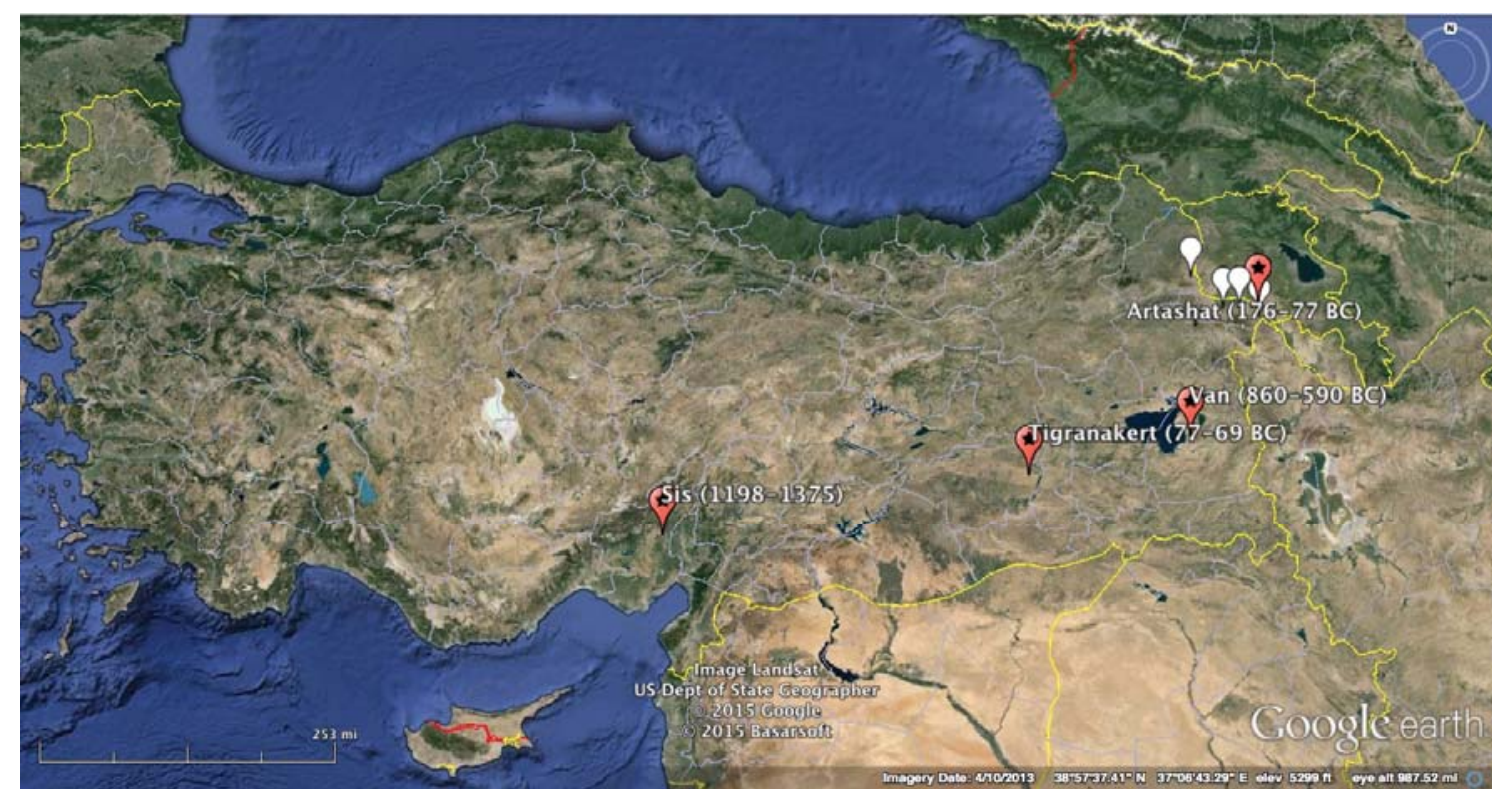

Figure 9: Map of Historical Capitals of Armenian Kingdoms

conditional on observables that might have driven selection in the past, locations of Armenian capitals were not systematically influenced by factors that matter for modern economic development, and proximity to Armenian capitals predict economic development only through historical Armenian presence. ${ }^{72}$ Although these places were economically more significant than the locations in their periphery as long as they served as Armenian capitals, they mostly lost their relative significance when the aforementioned Armenian kingdoms collapsed. For example, in the decades that follow Armenian Kingdom's defeat by the Roman army, Tigranakert/Silvan lost its importance as a thriving center for trade and Hellenistic culture. Alternatively, the ancient city of Artashat, after losing its status as a capital to Vagharshapat, gradually lost its significance. It continued to serve as one of the political and cultural centres of Armenia until it was completely destroyed by

\footnotetext{
${ }^{72}$ In support of this assumption, in the reduced form relationship between distances to Armenian capitals and luminosity, none of the instruments has any significant effect when we restrict the sample to districts with an Armenian share less than the 25th percentile of the Armenian distribution. We elaborate on this below. See Table 9.
} 
the Sassanid Persian army and disappeared from the map as ancient Artashat. Only in 1945, the modern town of Artashat was resuscitated by the Soviets in a location $8 \mathrm{~km}$ away from the ancient Artashat. This modern town exists to date as a small town of about 22 thousand people. At the same time, after the conquest of Cilicia by Timur in the 14th century, a larger number of wealthy Armenians left Sis/Kozan and settled in Cyprus. Also, numerous merchant families fled westward to find refuge with the existing diaspora communities in Western Europe. On the other hand, the regional economic importance of Van proved to be more persistent. Nevertheless, our IV results remain statistically significant when we exclude distance to either of these capitals from the set of our instruments.

Table 8 presents the results. For comparison purposes, columns (1) and (8) show the OLS estimates with and without historical correlates of development. A priori, we do not have any reason to think that one of the instruments would have better predictive power for Armenian presence than others. Thus, in column (2), we start by instrumenting Armenian share with distances to all four capitals. In the first stage, distances to Van, Silvan and Sis significantly predict Armenian presence, however, distance to Artashat has no significant predictive power. Nevertheless, with a value of 12.26 for the Kleibergen-Paap F-statistic, our instruments are altogether a strong predictor of Armenian presence at the end of 19th century. In the second stage, we see that Armenian share has a positive effect on economic activity, and this effect is significant at the 1 percent level. In column (3), given the low predictive power of distance to Artashat for Armenian presence, we proceed with three instruments as distances to Van, Silvan and Sis. This improves the first stage predictive power and the F-stat moves up to 15.71. In the second stage, Armenian presence positively and significantly affects economic activity. In the remaining columns, we alternate the set of instruments, and the results are qualitatively the same. Column (4) gives the highest F-stat value of 18.25, when we use distances to Silvan and Sis as instruments. In the second stage, a move of the instrumented Armenian share from the 10th to the 90th percentile increases luminosity by $55 \%$. Column (7) provides a just-identified model, although throughout all of the over-identified specifications the p-values for Hansen's J-stat are rather high so as to give support to the exogeneity of the instruments assumption. Lastly, column (9) uses again the set of instruments with the largest F-stat, distances to Silvan and Sis, while controlling for the historical correlates of development. Even under this stringent specification, second stage estimate suggests that a move of the Armenian 
share from the 10 th to the 90 th percentile increases luminosity by $28 \%$, significant at the 10 percent level.

TABLE 8: Armenian Share and Average Luminosity, IV Estimates

\begin{tabular}{|c|c|c|c|c|c|c|c|c|c|}
\hline Second stage & $\begin{array}{l}(1) \\
\text { OLS }\end{array}$ & $\begin{array}{c}(2) \\
\text { IV-GMM }\end{array}$ & $\begin{array}{c}(3) \\
\text { IV-GMM }\end{array}$ & $\begin{array}{c}(4) \\
\text { IV-GMM }\end{array}$ & $\begin{array}{c}(5) \\
\text { IV-GMM }\end{array}$ & $\begin{array}{c}(6) \\
\text { IV-GMM }\end{array}$ & $\begin{array}{c}(7) \\
\text { IV-GMM }\end{array}$ & $\begin{array}{l}(8) \\
\text { OLS }\end{array}$ & $\begin{array}{c}(9) \\
\text { IV-GMM }\end{array}$ \\
\hline & \multicolumn{9}{|c|}{ Log(Average Luminosity in 2000) } \\
\hline Armenian share, 1881-1893 (instrumented) & $\begin{array}{c}1.228^{* * *} \\
{[0.408]}\end{array}$ & $\begin{array}{c}3.338^{* * *} \\
{[0.728]}\end{array}$ & $\begin{array}{c}3.110^{* * *} \\
{[0.928]}\end{array}$ & $\begin{array}{c}2.794^{* *} \\
{[1.181]}\end{array}$ & $\begin{array}{c}2.926^{* * *} \\
{[1.070]}\end{array}$ & $\begin{array}{c}3.567^{* * *} \\
{[1.009]}\end{array}$ & $\begin{array}{c}3.569^{* * *} \\
{[1.013]}\end{array}$ & $\begin{array}{l}0.548 \\
{[0.371]}\end{array}$ & $\begin{array}{l}1.411^{*} \\
{[0.752]}\end{array}$ \\
\hline Log(Population density, 1927) & $\begin{array}{c}0.687^{* * *} \\
{[0.086]}\end{array}$ & $\begin{array}{c}0.684^{* * *} \\
{[0.081]}\end{array}$ & $\begin{array}{c}0.690^{* * *} \\
{[0.082]}\end{array}$ & $\begin{array}{c}0.687^{* * *} \\
{[0.083]}\end{array}$ & $\begin{array}{c}0.692^{* * *} \\
{[0.082]}\end{array}$ & $\begin{array}{c}0.695^{* * *} \\
{[0.082]}\end{array}$ & $\begin{array}{c}0.695^{* * *} \\
{[0.083]}\end{array}$ & $\begin{array}{c}0.446^{* * *} \\
{[0.069]}\end{array}$ & $\begin{array}{c}0.475^{* * *} \\
{[0.066]}\end{array}$ \\
\hline $\begin{array}{l}\text { Effect of increasing Armenian share } \\
\text { from the } 10 \text {-th to the } 90 \text {-th percentile }\end{array}$ & $\begin{array}{c}24.445^{* * *} \\
{[8.116]}\end{array}$ & $\begin{array}{c}66.413^{* * *} \\
{[14.478]}\end{array}$ & $\begin{array}{c}61.879^{* * *} \\
{[18.457]}\end{array}$ & $\begin{array}{l}55.593^{* *} \\
{[23.502]}\end{array}$ & $\begin{array}{c}58.218^{* * *} \\
{[21.298]}\end{array}$ & $\begin{array}{c}70.987^{* * *} \\
{[20.082]}\end{array}$ & $\begin{array}{l}71.029^{* * *} \\
{[20.160]}\end{array}$ & $\begin{array}{l}10.913 \\
{[7.375]}\end{array}$ & $\begin{array}{l}28.068^{*} \\
{[14.962]}\end{array}$ \\
\hline \multirow[t]{2}{*}{ First stage } & & $\begin{array}{l}(2) \\
\text { OLS }\end{array}$ & $\begin{array}{l}(3) \\
\text { OLS }\end{array}$ & $\begin{array}{l}(4) \\
\text { OLS }\end{array}$ & $\begin{array}{l}(5) \\
\text { OLS }\end{array}$ & $\begin{array}{c}(6) \\
\text { OLS }\end{array}$ & $\begin{array}{l}(7) \\
\text { OLS }\end{array}$ & & $\begin{array}{l}\text { (9) } \\
\text { OLS }\end{array}$ \\
\hline & \multicolumn{9}{|c|}{ Armenian share, $1881-1893$} \\
\hline Log distance to Van & & $\begin{array}{c}-0.077^{* *} \\
{[0.031]}\end{array}$ & $\begin{array}{c}-0.077^{* *} \\
{[0.032]}\end{array}$ & & $\begin{array}{c}-0.091^{* *} \\
{[0.042]}\end{array}$ & $\begin{array}{c}-0.071^{* *} \\
{[0.029]}\end{array}$ & $\begin{array}{c}-0.084^{* *} \\
{[0.038]}\end{array}$ & & \\
\hline Log distance to Silvan & & $\begin{array}{c}-0.061^{* * *} \\
{[0.014]}\end{array}$ & $\begin{array}{c}-0.059^{* * *} \\
{[0.013]}\end{array}$ & $\begin{array}{c}-0.069^{* * *} \\
{[0.015]}\end{array}$ & & $\begin{array}{c}-0.056^{* * *} \\
{[0.014]}\end{array}$ & & & $\begin{array}{c}-0.062^{* * *} \\
{[0.017]}\end{array}$ \\
\hline Log distance to Sis & & $\begin{array}{c}-0.061^{* * *} \\
{[0.016]}\end{array}$ & $\begin{array}{c}-0.062^{* * *} \\
{[0.016]}\end{array}$ & $\begin{array}{c}-0.059^{* * *} \\
{[0.016]}\end{array}$ & $\begin{array}{c}-0.060^{* * *} \\
{[0.016]}\end{array}$ & & & & $\begin{array}{c}-0.061^{* * *} \\
{[0.013]}\end{array}$ \\
\hline Log distance to Artashat & & $\begin{array}{c}0.036 \\
{[0.116]}\end{array}$ & & & & & & & \\
\hline Baseline Controls & $\checkmark$ & $\checkmark$ & $\checkmark$ & $\checkmark$ & $\checkmark$ & $\checkmark$ & $\checkmark$ & $\checkmark$ & $\checkmark$ \\
\hline $\begin{array}{l}\text { Modern subregion dummies } \\
\text { Robustness Controls }\end{array}$ & $\checkmark$ & $\checkmark$ & $\checkmark$ & $\checkmark$ & $\checkmark$ & $\checkmark$ & $\checkmark$ & $\checkmark$ & $\checkmark$ \\
\hline Observations & 757 & 757 & 757 & 757 & 757 & 757 & 757 & 757 & 757 \\
\hline Hansen J statistic p-value & - & 0.805 & 0.656 & 0.371 & 0.343 & 0.971 & - & - & 0.060 \\
\hline Kleibergen-Paap F-statistic & - & 12.261 & 15.714 & 18.256 & 13.935 & 10.425 & 6.995 & - & 24.484 \\
\hline Partial R2 on excluded instruments & - & 0.104 & 0.103 & 0.081 & 0.077 & 0.049 & 0.027 & - & 0.084 \\
\hline
\end{tabular}

Notes: This table presents the results from the IV regressions of Log Average Luminosity in 2000 on historical Armenian shares controlling for past population density, geographical variables, historical correlates of economic development, and subregion fixed effects. Historical Armenian silvan, Sis, and Artashat. The estimated is expressed in terms of $\%$ change in the level of average luminosity in district. Robust standard errors, clustered at the modern Turkish province
$(i l)$ level, are reported in square brackets. *** denotes statistical significance at the 1 percent level, $* *$ at the 5 percent level, and $*$ at the 10 percent level.

Importantly, to evaluate the plausibility of our exclusion restriction assumption that proximity to ancient Armenian capitals predict modern economic development only through historical Armenian presence, we investigate the reduced form relationship between distances to Armenian capitals and luminosity in a "placebo" sample of districts with an Armenian share less than the 25th percentile of the Armenian distribution. The idea is that proximity to Armenian capitals should not predict modern economic activity when there is no significant amount of Armenian presence. Table 9 presents the results. None of the instruments have any significant association with luminosity in the placebo sample. Thus, this simple placebo exercise is supportive of the 
identifying assumption that the only effect of proximity to Armenian capitals on luminosity is through its influence on historical Armenian presence.

TABle 9: Reduced Form Placebo Regressions for Armenian Instruments

\begin{tabular}{|c|c|c|c|c|c|c|c|}
\hline Placebo Sample: Armenian Share $<25$ th Percentile & $\begin{array}{c}(1) \\
\text { OLS }\end{array}$ & $\begin{array}{c}(2) \\
\text { OLS }\end{array}$ & $\begin{array}{c}(3) \\
\text { OLS }\end{array}$ & $\begin{array}{c}(4) \\
\text { OLS }\end{array}$ & $\begin{array}{c}(5) \\
\text { OLS }\end{array}$ & $\begin{array}{c}(6) \\
\text { OLS }\end{array}$ & $\begin{array}{c}(7) \\
\text { OLS }\end{array}$ \\
\hline & \multicolumn{7}{|c|}{ Log(Average Luminosity in 2000) } \\
\hline Log distance to Van & $\begin{array}{l}-0.767 \\
{[1.447]}\end{array}$ & $\begin{array}{c}0.720 \\
{[1.129]}\end{array}$ & & $\begin{array}{c}0.456 \\
{[0.818]}\end{array}$ & $\begin{array}{c}0.673 \\
{[1.089]}\end{array}$ & $\begin{array}{c}0.472 \\
{[0.810]}\end{array}$ & \\
\hline Log distance to Silvan & $\begin{array}{l}-0.271 \\
{[0.652]}\end{array}$ & $\begin{array}{l}-0.258 \\
{[0.731]}\end{array}$ & $\begin{array}{l}-0.036 \\
{[0.509]}\end{array}$ & & $\begin{array}{l}-0.188 \\
{[0.628]}\end{array}$ & & $\begin{array}{c}1.183 \\
{[0.850]}\end{array}$ \\
\hline Log distance to Sis & $\begin{array}{c}0.105 \\
{[0.230]}\end{array}$ & $\begin{array}{c}0.070 \\
{[0.250]}\end{array}$ & $\begin{array}{c}0.053 \\
{[0.249]}\end{array}$ & $\begin{array}{c}0.038 \\
{[0.218]}\end{array}$ & & & $\begin{array}{c}0.309 \\
{[0.304]}\end{array}$ \\
\hline Log distance to Artashat & $\begin{array}{c}3.202 \\
{[2.756]}\end{array}$ & & & & & & \\
\hline Observations & 190 & 190 & 190 & 190 & 190 & 190 & 190 \\
\hline R-squared & 0.619 & 0.616 & 0.615 & 0.616 & 0.616 & 0.616 & 0.688 \\
\hline Baseline Controls & $\checkmark$ & $\checkmark$ & $\checkmark$ & $\checkmark$ & $\checkmark$ & $\checkmark$ & $\checkmark$ \\
\hline Modern subregion dummies & $\checkmark$ & $\checkmark$ & $\checkmark$ & $\checkmark$ & $\checkmark$ & $\checkmark$ & $\checkmark$ \\
\hline Robustness Controls & & & & & & & $\checkmark$ \\
\hline
\end{tabular}

Notes: This table presents the reduced form results from regressions of Log Average Luminosity in 2000 on log distances to various combinations of historical capitals of Armenian kingdoms Van, Silvan, Sis, and Artashat for the placebo sample where Armenian shares are less than the 25th percentile of the cross-district distribution of Armenian shares, controlling for past population density, baseline geographical variables, historical correlates of economic development, and subregion fixed effects. Robust standard errors, clustered at the modern Turkish province (il) level, are reported in square brackets. *** denotes statistical significance at the 1 percent level, ** at the 5 percent level, and $*$ at the 10 percent level.

Greek IV Estimates. In order to predict the 19th century Greek population distribution across Anatolia, we have identified ancient Greek sites through the Classical (480-323 BC) and the Hellenistic (323-146 BC) periods. Ancient Greek sites predict Greek presence after two millennia to the extent that ancient settlement patterns persisted into the late 19th century. The map of Ancient Greek sites is in Figure 10. ${ }^{73}$ In this map major and minor settlements of Ancient Greece are identified from multiple sources, original research papers, old and modern maps, and ancient texts relevant to each place on the map. ${ }^{74}$ We do not have information about the size of a given settlement, thus we can only count the number of ancient Greek sites in a district. We use the number of ancient Greek settlements within a radius of 20 to $50 \mathrm{~km}$ of a given district to instrument Greek presence in $1893 .{ }^{75}$

\footnotetext{
${ }^{73}$ Darker shades on the map refer to the Classical period, while lighter shades refer to the Hellenistic period.

${ }^{74}$ Available at http://ancient-greece.org.

${ }^{75}$ Note that an ancient Greek site can be assigned to multiple districts if it lies within a given radius of multiple districts.
} 


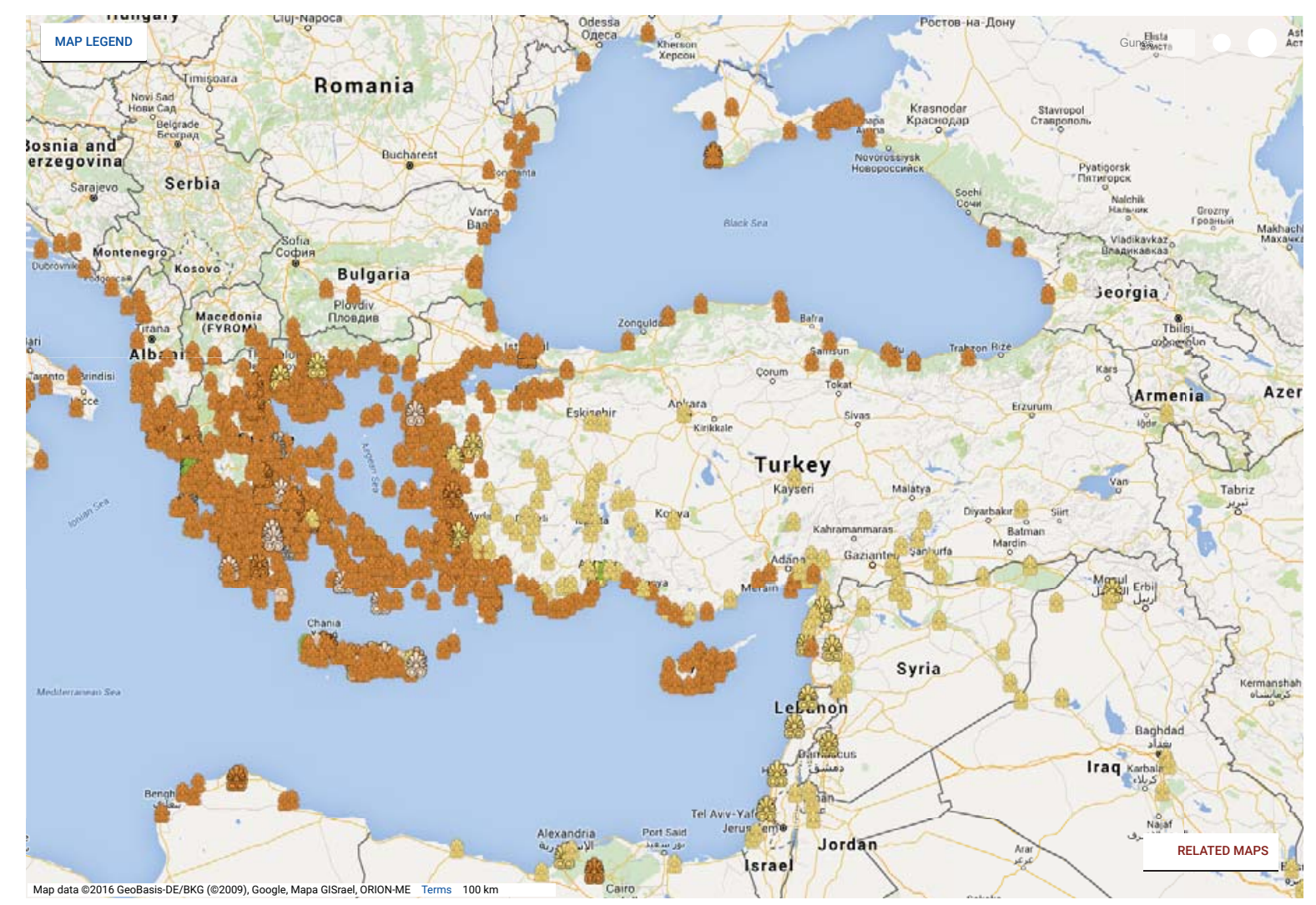

Notes: Darker shades on the map refer to the Classical period, while lighter shades refer to the Hellenistic period.

Figure 10: Map of Ancient Greek Sites from 500 BC to 146 BC

Exclusion restriction assumption is that, conditional on observables, the determinants of ancient Greek settlements millennia ago are orthogonal to the drivers of modern economic development, and the ancient Greek sites affect economic development today only through historical Greek presence. ${ }^{76}$

The results are presented in Table 10. Columns (1) and (7) provide the OLS estimates with and without historical correlates of development. In columns (2) to (5), Greek share in 1893 is instrumented with the number of ancient Greek sites within 20 to $50 \mathrm{~km}$ radius of a district. Number of ancient Greek sites within 40 and 50km radius have the largest predictive power for Greek

\footnotetext{
${ }^{76}$ In fact, a cursory look at Figure 10 suggests that ancient Greek settlers were not necessarily strategic, and, upon leaving the mainland Greece, they moved rather mechanically along the coastal line. More importantly, in support of this assumption, in the reduced form relationship between the number of ancient Greek sites and luminosity, none of the instruments has any significant effect when we restrict the sample to districts with a Greek share less than the 25th percentile of the Greek distribution. We elaborate on that below. See Table 11.
} 
share with F-statistics of about 20. All throughout, instrumented Greek share has a positive and significant effect on luminosity in the second stage. Column (6) shows that the number of ancient Greek sites between 50 to $70 \mathrm{~km}$ radius have no predictive power for historical Greek presence. Finally, in column (8), we control for historical correlates of development while instrumenting the Greek share with the number of ancient Greek sites within 50km (F-stat=19.3). The effect of Greek share on luminosity is still positive and significant at the 1 percent level. Importantly, in column (8), the first stage coefficient on the number of Greek sites (and also the F-stat) is statistically the same as the one in column (5) when we do not control for the historical correlates of development. This suggests that, once we control for the exogenous baseline characteristics, the distribution of ancient Greek sites is orthogonal to the historical correlates of development, and our instruments do not appear to influence Greek shares in the late 19th century through historical correlates of development such as the distance to trade routes. Therefore, conditional on geography which predates every other variable, the concentration of Greek sites seem to capture a deeper and more persistent settlement and diffusion process that is not driven by trade routes, major railroads, major ports, etc.

Finally, it is important to evaluate how plausible the exclusion restriction assumption is (that ancient Greek sites predict modern economic development only through historical Greek presence). To that end, we investigate the reduced form relationship between the number of ancient Greek sites and luminosity in a "placebo" sample of districts with a Greek share less than the 25th percentile of the Greek distribution. Table 11 presents the results. None of the instruments have a meaningful effect on luminosity in the placebo sample. Hence, this simple placebo exercise provides support for the hypothesis that the only influence of ancient Greek sites on luminosity is to the extent that ancient Greek sites predict historical Greek presence at the end of 19th century.

Explaining size differences between OLS and IV estimates. IV estimates for Armenian share imply an effect that is larger than the size of the OLS estimates (compare columns (1) and (4) in Table 8). For Greek estimates, the difference is more substantial (see columns (1) and (5) in Table 10). Several factors might be responsible for these differences.

First, our instruments are intended to exploit the part of variation in late 19th century minority shares which date back to Antiquity and even to earlier periods. As a corollary, the 
TABLE 10: Greek Share and Average Luminosity, IV Estimates

\begin{tabular}{|c|c|c|c|c|c|c|c|c|c|}
\hline Second stage & $\begin{array}{l}(1) \\
\text { OLS }\end{array}$ & $\begin{array}{c}(2) \\
\text { IV-GMM }\end{array}$ & $\begin{array}{c}(3) \\
\text { IV-GMM }\end{array}$ & $\begin{array}{c}(4) \\
\text { IV-GMM }\end{array}$ & $\begin{array}{c}(5) \\
\text { IV-GMM }\end{array}$ & $\begin{array}{c}(6) \\
\text { IV-GMM }\end{array}$ & $\begin{array}{l}(7) \\
\text { OLS }\end{array}$ & $\begin{array}{c}(8) \\
\text { IV-GMM }\end{array}$ & $\begin{array}{c}(9) \\
\text { IV-GMM }\end{array}$ \\
\hline & \multicolumn{9}{|c|}{ Log(Average Luminosity in 2000) } \\
\hline Greek population share, 1881-1893 (instrumented) & $\begin{array}{c}1.231^{* * *} \\
{[0.341]}\end{array}$ & $\begin{array}{l}7.450^{*} \\
{[4.385]}\end{array}$ & $\begin{array}{l}7.087^{* *} \\
{[2.956]}\end{array}$ & $\begin{array}{c}7.409^{* * *} \\
{[2.409]}\end{array}$ & $\begin{array}{c}5.420^{* * *} \\
{[1.835]}\end{array}$ & $\begin{array}{l}-1.050 \\
{[3.750]}\end{array}$ & $\begin{array}{c}0.720^{* * *} \\
{[0.275]}\end{array}$ & $\begin{array}{c}4.271^{* * *} \\
{[1.469]}\end{array}$ & $\begin{array}{c}0.491 \\
{[3.883]}\end{array}$ \\
\hline Log(Population density, 1927) & $\begin{array}{c}0.674^{* * *} \\
{[0.084]}\end{array}$ & $\begin{array}{c}0.628^{* * *} \\
{[0.092]}\end{array}$ & $\begin{array}{c}0.631^{* * *} \\
{[0.091]}\end{array}$ & $\begin{array}{c}0.628^{* * *} \\
{[0.092]}\end{array}$ & $\begin{array}{c}0.643^{* * *} \\
{[0.083]}\end{array}$ & $\begin{array}{c}0.691^{* * *} \\
{[0.103]}\end{array}$ & $\begin{array}{c}0.444^{* * *} \\
{[0.069]}\end{array}$ & $\begin{array}{c}0.474^{* * *} \\
{[0.077]}\end{array}$ & $\begin{array}{c}0.442^{* * *} \\
{[0.070]}\end{array}$ \\
\hline $\begin{array}{l}\text { Effect of increasing Greek share } \\
\text { from the 10-th to the } 90 \text {-th percentile }\end{array}$ & $\begin{array}{c}31.726^{* * *} \\
{[8.793]}\end{array}$ & $\begin{array}{l}192.046^{*} \\
{[113.032]}\end{array}$ & $\begin{array}{c}182.682^{* *} \\
{[76.200]}\end{array}$ & $\begin{array}{c}190.988^{* * *} \\
{[62.089]}\end{array}$ & $\begin{array}{c}139.700^{* * *} \\
{[47.301]}\end{array}$ & $\begin{array}{l}-27.054 \\
{[96.667]}\end{array}$ & $\begin{array}{c}18.567^{* * *} \\
{[7.096]}\end{array}$ & $\begin{array}{c}110.092^{* * *} \\
{[37.874]}\end{array}$ & $\begin{array}{c}12.666 \\
{[100.099]}\end{array}$ \\
\hline \multirow[t]{2}{*}{ First stage } & & $\begin{array}{l}(2) \\
\text { OLS }\end{array}$ & $\begin{array}{c}(3) \\
\text { OLS }\end{array}$ & $\begin{array}{l}\text { (4) } \\
\text { OLS }\end{array}$ & $\begin{array}{l}(5) \\
\text { OLS }\end{array}$ & $\begin{array}{l}(6) \\
\text { OLS }\end{array}$ & & $\begin{array}{c}(8) \\
\text { OLS }\end{array}$ & $\begin{array}{c}(9) \\
\text { OLS }\end{array}$ \\
\hline & \multicolumn{9}{|c|}{ Greek share, $1881-1893$} \\
\hline $\log (1+\#$ of Ancient Greek Sites within 20km) & & $\begin{array}{l}0.037^{*} \\
{[0.020]}\end{array}$ & & & & & & & \\
\hline $\log (1+\#$ of Ancient Greek Sites within $30 \mathrm{~km})$ & & & $\begin{array}{c}0.041^{* * *} \\
{[0.014]}\end{array}$ & & & & & & \\
\hline $\log (1+\#$ of Ancient Greek Sites within 40km) & & & & $\begin{array}{c}0.043^{* * *} \\
{[0.011]}\end{array}$ & & & & & \\
\hline $\log (1+\#$ of Ancient Greek Sites within 50km) & & & & & $\begin{array}{c}0.042^{* * *} \\
{[0.011]}\end{array}$ & & & $\begin{array}{c}0.040^{* * *} \\
{[0.011]}\end{array}$ & \\
\hline $\log (1+\#$ of Ancient Greek Sites within $50-70 \mathrm{~km})$ & & & & & & $\begin{array}{c}0.019 \\
{[0.012]}\end{array}$ & & & $\begin{array}{c}0.013 \\
{[0.011]}\end{array}$ \\
\hline Baseline Controls & $\checkmark$ & $\checkmark$ & $\checkmark$ & $\checkmark$ & $\checkmark$ & $\checkmark$ & $\checkmark$ & $\checkmark$ & $\checkmark$ \\
\hline $\begin{array}{l}\text { Modern subregion dummies } \\
\text { Robustness Controls }\end{array}$ & $\checkmark$ & $\checkmark$ & $\checkmark$ & $\checkmark$ & $\checkmark$ & $\checkmark$ & $\checkmark$ & $\checkmark$ & $\checkmark$ \\
\hline Observations & 757 & 757 & 757 & 757 & 757 & 757 & 757 & 757 & 757 \\
\hline Kleibergen-Paap F-statistic & - & 6.272 & 13.415 & 20.246 & 19.572 & 2.908 & - & 19.311 & 1.801 \\
\hline Partial R2 on excluded instruments & - & 0.016 & 0.030 & 0.037 & 0.037 & 0.008 & - & 0.041 & 0.004 \\
\hline
\end{tabular}

Notes: This table presents the results from the IV regressions of Log Average Luminosity in 2000 on historical Greek shares controlling for past population density, geographical variables, historical correlates of economic development, and subregion fixed effects. Historical Greek shares are instrumented by the number of ancient Greek settlements within a given radius of the district center. The estimated effect associated with increasing minority shares from the tenth to the ninetieth percentile of their respective cross-district distributions is expressed in terms of \% change in the level of average luminosity in district. Robust standard errors, clustered at the modern Turkish province (il) level, are reported in square brackets. *** denotes statistical significance at the 1 percent level, ** at the 5 percent level, and $*^{*}$ at the 10 percent level.

instrumented variations in minority shares may not fully capture the actual magnitudes of human capital loss each district experienced due to expulsions in the early 20th century. The OLS estimates, on the other hand, would reflect this adverse effect more and produce estimates of a long-run effect that is dampened due to a possibly persistent negative influence of the shocks themselves, rather than capturing only the positive minority legacy.

Second, if minority settlement patterns are governed by negative selection on development potential (after conditioning on geographical factors) then the OLS coefficients would also understate the causal effect of minority presence on economic activity. Comparing the locational distribution of Armenians and Greeks as of late 19th century, and considering the constraints on territorial expansion each group faced throughout history, we believe that this negative selection story should be more relevant for Armenians than for Greeks. Therefore, while the aforemen- 
TABle 11: Reduced Form Placebo Regressions for Greek Instruments

\begin{tabular}{|c|c|c|c|c|c|}
\hline Placebo Sample: Greek Share $<25$ th Percentile & $\begin{array}{c}(1) \\
\text { OLS }\end{array}$ & $\begin{array}{c}(2) \\
\text { OLS }\end{array}$ & $\begin{array}{c}(3) \\
\text { OLS }\end{array}$ & $\begin{array}{c}(4) \\
\text { OLS }\end{array}$ & $\begin{array}{c}(5) \\
\text { OLS }\end{array}$ \\
\hline & \multicolumn{5}{|c|}{ Log(Average Luminosity in 2000) } \\
\hline $\log (1+\#$ of Ancient Greek Sites within 20km) & $\begin{array}{c}0.197 \\
{[0.325]}\end{array}$ & & & & \\
\hline $\log (1+\#$ of Ancient Greek Sites within 30km) & & $\begin{array}{c}0.269 \\
{[0.160]}\end{array}$ & & & \\
\hline $\log (1+\#$ of Ancient Greek Sites within 40km) & & & $\begin{array}{c}0.148 \\
{[0.251]}\end{array}$ & & \\
\hline $\log (1+\#$ of Ancient Greek Sites within 50km) & & & & $\begin{array}{c}0.149 \\
{[0.231]}\end{array}$ & $\begin{array}{l}-0.005 \\
{[0.235]}\end{array}$ \\
\hline Observations & 189 & 189 & 189 & 189 & 189 \\
\hline R-squared & 0.384 & 0.388 & 0.384 & 0.384 & 0.482 \\
\hline Baseline Controls & $\checkmark$ & $\checkmark$ & $\checkmark$ & $\checkmark$ & $\checkmark$ \\
\hline Modern subregion dummies & $\checkmark$ & $\checkmark$ & $\checkmark$ & $\checkmark$ & $\checkmark$ \\
\hline Robustness Controls & & & & & $\checkmark$ \\
\hline
\end{tabular}

Notes: This table presents the reduced form results from regressions of Log Average Luminosity in 2000 on the number of ancient Greek settlements within a given radius of the district center for the placebo sample where Greek shares are less than the 25th percentile of the cross-district distribution of Greek shares, controlling for past population density, baseline geographical variables, historical correlates of economic development,
and subregion fixed effects. Robust standard errors, clustered at the modern Turkish province (il) level, are reported in square brackets. $* * *$ denotes statistical significance at the 1 percent level, ** at the 5 percent level, and * at the 10 percent level.

tioned reasons might partly justify lower OLS estimates, they are unlikely to explain why this understatement was more dramatic for Greeks than for Armenians.

The third explanation may also provide an answer to this question. In OLS regressions, Greek and Armenian shares in 1893 are intended as proxies for long-term and steady minority presence. In this sense these population shares could be highly noisy proxies if ethnoreligious composition in a given location was markedly different from that observed in the Ottoman Census -due to migration flows and other demographic shifts. This noise in measurement in turn would lead to attenuation bias. In our IV analysis for Greeks, we use proximity to ancient Greek settlements as our instrument, and this measure might serve as a substantially better proxy for the more persistent part of Greek presence than Greek share in 1893, thus, partly mitigating the attenuation bias in OLS estimates. A similar argument may not apply to the same extent in our IV analysis for Armenians, if distances to old Armenian kingdoms (our instruments for Armenian share in 1893) 
are not as strong as the number of ancient Greek sites in predicting persistent settlement patterns. Comparing the maps in Figures 9 and 10 can see that average distance to Armenian capitals from across all Turkish districts in our sample is way bigger than the corresponding average distance to Greek sites. Therefore, if proximity to historic centers becomes gradually less relevant in explaining deep-rooted settlement patterns as we move away from these centers, then we should indeed expect the IV-OLS differences to be more pronounced for Greeks than Armenians.

The fourth explanation for IV-OLS gaps is related to possibly selective Muslim penetration. Due to greater economic opportunities that prevailed in regions with higher Armenian and Greek concentration prior to Muslim arrival in Anatolia, Muslim penetration into these regions could have been relatively stronger than regions with lower ancient minority concentration. This selective process could lead to minority shares in 1893 that understate ancient minority presence. Thus, OLS may systematically underestimate the deep rooted minority contribution on local development.

Fifth, IV regressions estimate the local average treatment effect (LATE) which is different from the average treatment effect (ATE) when minority effects are heterogeneous. Considering all these explanations, our contention is that the difference between IV and OLS estimates are not unreasonably large after all.

\section{Potential Channels for Persistent Minority Legacy}

The results from the previous sections support the common wisdom that, over many centuries prior to their expulsion, Armenian and Greek communities played an important role in shaping regional patterns of development in Anatolia. The empirical evidence we have provided so far has revealed positive correlations between contemporary economic development and the regional concentration of the two largest non-Muslim groups in the Ottoman Empire. We interpret these findings as evidence of minority legacy. By and large, other interpretations do not square with the historical context. One alternative explanation could be that expulsions led to higher development because they reduced ethno-religious diversity in previously high-minority regions. If diversity was indeed harmful to development, then it is not clear why high-minority regions were ahead of more homogeneous regions even before the expulsions. ${ }^{77}$ One may alternatively argue for an intermediate

\footnotetext{
${ }^{77}$ We show that population densities were higher in high-minority regions before the expulsions.
} 
level of diversity that is optimal for development, and perhaps high-minority regions were above this threshold before the expulsions while low-minority regions were below it. This could in theory explain both pre- and the post-expulsion gaps in development, had it not been the case that with the expulsions religious diversity in affected regions was reduced to almost zero, rather than simply approaching the optimal level postulated in this theory. Finally, one could argue that inflow of Muslim immigrants that replaced Armenians and Greeks led to higher development. Once again, such a theory cannot explain pre-expulsion outcomes even though it is a plausible factor that might have contributed to subsequent development in historically high-minority locations. Yet, as a robustness check, we control for Muslim immigrant flows during 1921-1929 as a share of 1927 province population as well as the share of 1927 population who were born in the major senders of Muslim immigrants during the late 19th and the early 20th century; and our results remain qualitatively intact.

In sum, our findings are unlikely to be simply driven by expulsions per se. Instead, we view them as reflecting the persistent influence of the higher rates of human capital and physical capital accumulation among the non-Muslim subjects of the empire, and the ensuing benefits to the Muslim populations interacting with the minorities. In this section, we offer suggestive evidence for these two main channels.

\subsection{Minorities and Human Capital Accumulation}

Greeks and Armenians had a significant representation in highly skilled and educated segments of the Ottoman society. Just like Greeks, ${ }^{78}$ high levels of investment in human capital among Armenians had historical roots. Under the reign of Bagratuni (885-1045) in Armenia Major and in the Cilician Armenian Kingdom (1198-1375), Armenians enjoyed a period of persistent growth in science and culture. Elementary schools were subsidized by the state, and in the 9th and the 10th centuries, Armenian state established institutions of higher education, called Vardapetarans, in large cities (Khachikyan, 2010). Even in the relatively poorer eastern provinces such as the Erzurum vilayet, the education level of the Armenian population and the knowhow of Armenian artisans stood out vis-a-vis the Muslims (Kévorkian, 2011).

\footnotetext{
${ }^{78}$ Even in antiquity, education in a gymnasium was considered essential for participation in the Greek culture. Moreover, there is plenty of evidence about the important role of Greek education and science in world history, and the famous scientists and philosophers of Greek tradition.
} 
Due to the lack of sufficient state investment in education and other social infrastructure in the provinces, a significant majority of Muslims lacked adequate education and skills. In contrast, Greek and Armenian philanthropic agencies and the religious institutions were quite effective in channeling the community resources into education. Ottoman administration's neglect of Anatolia, especially the Eastern regions, also deepened the discrepancies in the quality of educational institutions between non-Muslim minorities and the Muslim majority. In support of this argument, we have seen already in Figure 4 that, based on data from Ottoman provinces in 1894/95, the average proportion of primary school students within non-Muslim population of Greeks and Armenians combined was about 1.6 times as high as the proportion of primary school students within the Muslim community.

In this section, we consider educational attainment, and human capital in general, as a potentially mediating variable between historical minority presence and contemporary economic development. There are several reasons to expect that education levels today would be higher in localities that were subject to greater Armenian and Greek influence in the past. One possible mechanism would be the diffusion of cultural values regarding the importance of education. This diffusion might have taken place through the observation by the local Muslims of the returns to education exemplified in the economic success of the more educated minority groups. Alternatively, higher demand for educated work force driven by the establishment of modern sectors by the minorities might have directly raised the level of human capital investment among the local Muslims or it could have generated incentives for more educated and highly skilled Muslims to migrate to regions with greater minority presence. Intergroup transmission of skills and knowledge in craftsmanship, trade and commerce might be another channel. Muslims working with or competing against non-Muslim minorities in the domestic market might have gained an advantage in adopting the knowhow and production techniques developed by Armenians and Greeks, compared to a Muslim businessman who had no such experience. ${ }^{79}$ Finally, the shops, businesses and other productive assets Greeks and Armenians left behind might have generated the incentives and

\footnotetext{
${ }^{79}$ Here the concept of human capital we have in mind is rather broad. To illustrate, consider a Muslim merchant who lived and worked side-by-side the minority communities. Through interpersonal interaction or by competing with minority merchants in his region, he might have not only learned the relevant knowledge and the skills, but also acquired the intangibles such as the entrepreneurial spirit or the norms of business. Once the minorities are gone, this merchant will be more ready to step up into certain modern sectors and businesses, compared to some other Muslim individual who lived in a Muslim-only town, and thus, has not observed or experienced any of the externalities from minorities.
} 
the means to invest in human capital among local Muslims that took over these assets. This involuntary transfer of wealth and productive assets might have facilitated over the early years of the Turkish Republic the emergence of a Muslim bourgeoisie with higher human capital. Ultimately, the intergenerational transmission of values regarding the importance of education would explain the persistence of higher levels of education into the contemporary period.

If the above argument about the diffusion and the spillover of human capital from nonMuslims to Muslims holds, then, already before the expulsions, we should see differences in education levels between Muslims who lived in high minority concentration areas and those Muslims who did not. Figure 11 shows exactly that. Figure 11 provides descriptive evidence about average primary school enrollment rates among Muslims in above and below median minority share Ottoman provinces in 1894/1895. ${ }^{80}$ Consistent with our argument about human capital spillovers, Muslims who lived in high minority areas had, on average, greater primary school enrollment rates than Muslims who lived in low minority areas.

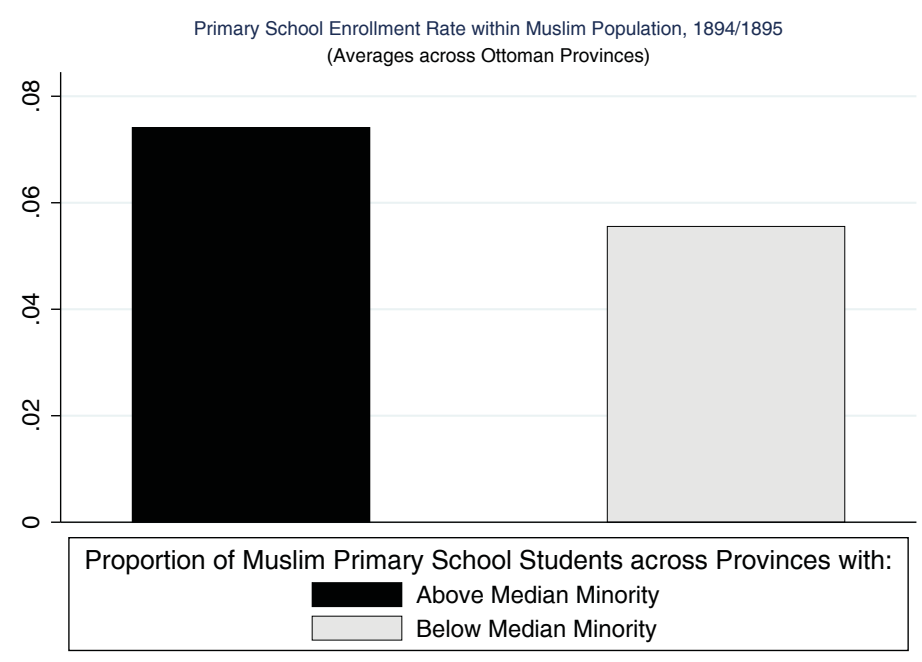

FIgURE 11: Educational attainment among Muslims in High vs. Low Minority Provinces, $1894 / 1895$

Although the evidence from Figure 11 is telling, it can only be suggestive. We test the same idea more thoroughly with the data on literacy rates from the 1927 Turkish Republic census. 1927 is the first Turkish census year after the expulsions took place, and a significant share of the Muslim population of the time must have coexisted with the minorities prior to expulsions. Also, it

\footnotetext{
${ }^{80}$ Based on data from Ottoman provinces in $1894 / 95$.
} 

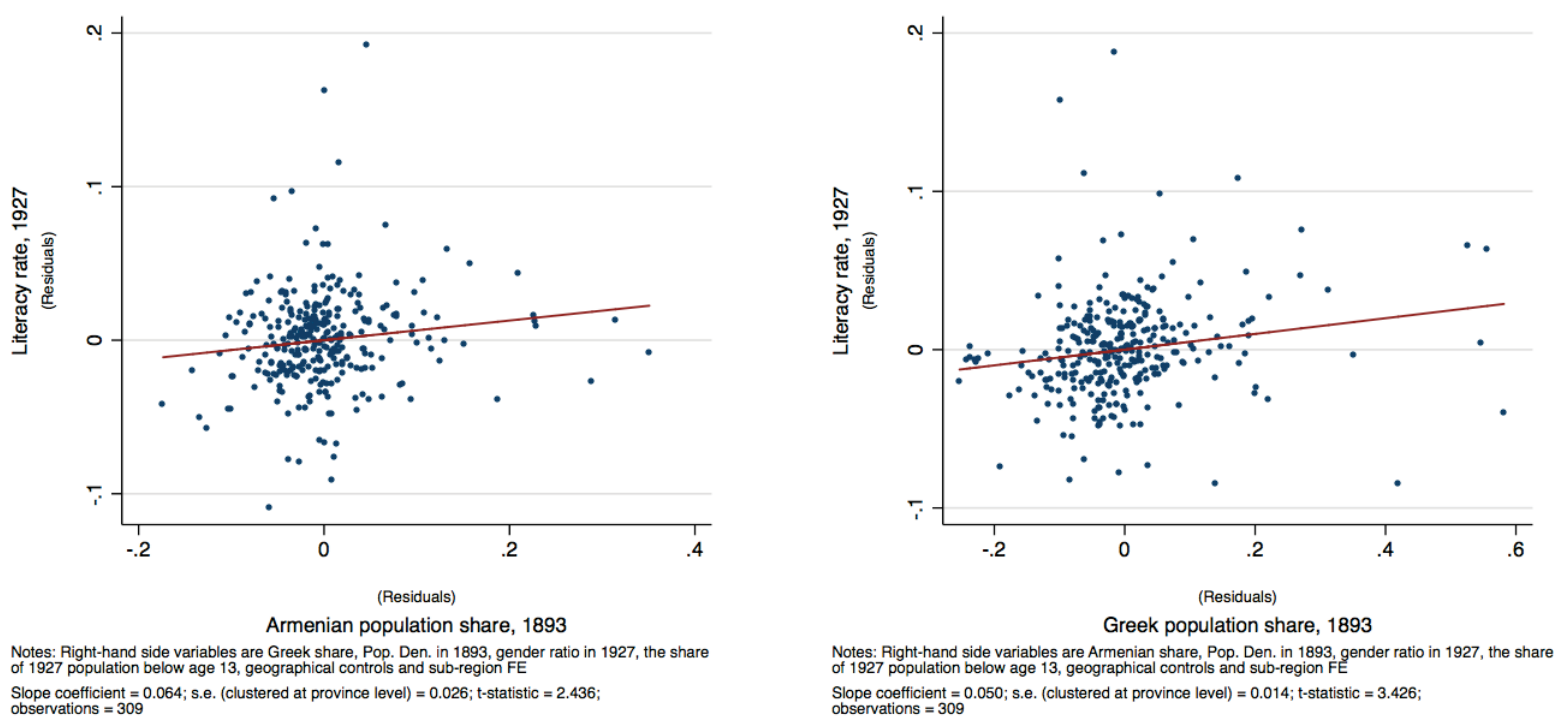

Figure 12: Historical Minority Presence and Literacy in 1927

is crucial to recall that $99 \%$ of Turkey was registered Muslim by 1927. Thus, literacy rates in 1927 capture to a large extent the human capital of remaining Muslims and not the direct contribution of non-Muslims. Figure 12 shows the relationships between the literacy rates in 1927, and Armenian and Greek shares in 1893, conditional on Greek or Armenian shares, population density in 1893, gender ratio in 1927, the share of population below 13 in 1927, baseline geographical controls, and subregion fixed effects. Both panels of Figure 12 suggest that literacy rates in 1927 among the remaining predominantly Muslim population are significantly higher in areas with greater share of historical Ottoman minorities in 1893. One percentage point increase in the historical Armenian share is associated with a 0.064 percentage point increase in the average literacy rate in 1927 , while the same effect for the Greek share is 0.050 percentage point. These coefficients are economically sizable given the average literacy rate at the time was $5.9 \%$. This means that, for example, a move from the 10th to the 90th percentile of the Armenian share (from 0 to 20\%) increases literacy rate by 1.28 percentage points which is more than one fifth of the average literacy rate of the time. These results support the human capital spillover hypothesis outlined above.

If the early spillovers of human capital and education persisted over time via intergenerational transmission of values, then, also in the contemporary period we should still observe greater levels of education in historically high minority areas. The results in Table 12 are supportive of this 
hypothesis, and suggest that historical Armenian and Greek presence is a significant and positive predictor of contemporary educational attainment at the district level.

In Panel A of Table 12, the outcome variable is high school completion rates in 2000. In Panel B we look at university completion rates in 2000. Results are qualitatively similar for both education outcomes. Column (1) shows that Armenian and Greek shares in 1893 are positive and significant predictors of educational attainment in contemporary Turkey. In column (2), we include the literacy rates in 1927 into the specification so as to understand how historical human capital spillovers mediate the effect of Ottoman minorities on current educational attainments. Literacy rates in 1927 are a significantly strong predictor of educational outcomes in $2000 .{ }^{81}$ Strikingly, once the literacy rates in 1927 are taken into account, the association between minority shares and contemporary education is mitigated. For example, when high school completion rates are the outcome variable, the Armenian and the Greek coefficients drop by 28 and 38 percents, respectively, upon controlling for literacy rates in 1927 (comparing Armenian and Greek share coefficients in columns (1) and (2) of Panel A). This suggests that part of the legacy of Ottoman minorities on current educational attainment is through their contribution to the historical human capital levels of their Muslim coinhabitants -as was evidenced in Figures 11 and 12.

To better identify the human capital channel we employ data on the locations of historical school buildings owned by various minority communities as of $1912 .{ }^{82}$ Then we create a variable by taking the ratio of the number of Armenian or Greek school buildings within a district to the size of the Muslim population in 1893. To the extent that school buildings captures the degree of human capital accumulation at the local level, this variable proxies the intensity of exposure to Armenian or Greek human capital by an average Muslim individual before the expulsions. It also allows us to better capture the variation in human capital of the members of each minority group who lived in different regions. This way we can test the human capital influence at the intensive margin. Typically, the degree of interaction across inter-ethnoreligious groups was greater in more

\footnotetext{
${ }^{81}$ In column (2) we also control for the share of 1927 population younger than 13 and the female-male ratio to isolate the part of literacy that is not driven by gender gap in educational attainment or the age structure of the population.

${ }^{82}$ These data are from the Hrant Dink Foundation who runs a project to map and preserve the cultural heritage of Anatolia before the minorities were removed. The project documents Armenian, Greek, Syriac, and Jewish cultural heritage. Although the data is the most comprehensive inventory minority buildings to date, it is not fully complete. Greek buildings are relatively underdocumented compared to Armenian buildings. The interactive map is available at http://turkiyekulturvarliklari.hrantdink.org/en/.
} 
TABLE 12: Minorities, their schools and educational attainment in 2000

\begin{tabular}{|c|c|c|c|c|c|c|c|c|}
\hline & $\begin{array}{l}(1) \\
\text { OLS }\end{array}$ & $\begin{array}{l}(2) \\
\text { OLS }\end{array}$ & $\begin{array}{l}(3) \\
\text { OLS }\end{array}$ & $\begin{array}{l}(4) \\
\text { OLS }\end{array}$ & $\begin{array}{l}(5) \\
\text { OLS }\end{array}$ & $\begin{array}{c}(6) \\
\text { IV-GMM }\end{array}$ & $\begin{array}{l}\text { (7) } \\
\text { OLS }\end{array}$ & $\begin{array}{c}(8) \\
\text { IV-GMM }\end{array}$ \\
\hline & \multicolumn{8}{|c|}{ PANEL A: High school Completion in 2000} \\
\hline Armenian population share, 1893 & $\begin{array}{c}0.109^{* * *} \\
{[0.030]}\end{array}$ & $\begin{array}{c}0.079^{* * *} \\
{[0.025]}\end{array}$ & $\begin{array}{l}0.059^{*} \\
{[0.034]}\end{array}$ & $\begin{array}{c}0.040 \\
{[0.030]}\end{array}$ & $\begin{array}{c}0.107^{* * *} \\
{[0.030]}\end{array}$ & $\begin{array}{c}0.251 * * * \\
{[0.090]}\end{array}$ & & \\
\hline Greek population share, 1893 & $\begin{array}{c}0.107^{* * * *} \\
{[0.030]}\end{array}$ & $\begin{array}{c}0.067^{* *} \\
{[0.030]}\end{array}$ & $\begin{array}{c}0.087^{* *} \\
{[0.038]}\end{array}$ & $\begin{array}{l}0.053 \\
{[0.037]}\end{array}$ & & & $\begin{array}{c}0.106^{* * *} \\
{[0.030]}\end{array}$ & $\begin{array}{c}0.469^{* * *} \\
{[0.157]}\end{array}$ \\
\hline Literacy rate in 1927 & & $\begin{array}{c}0.386^{* * *} \\
{[0.068]}\end{array}$ & & $\begin{array}{c}0.356^{* * *} \\
{[0.063]}\end{array}$ & & & & \\
\hline Pop. share of age <13 in 1927 & & $\begin{array}{c}0.024 \\
{[0.104]}\end{array}$ & & $\begin{array}{c}0.048 \\
{[0.102]}\end{array}$ & & & & \\
\hline Female-male ratio in 1927 & & $\begin{array}{l}-0.020 \\
{[0.024]}\end{array}$ & & $\begin{array}{l}-0.029 \\
{[0.026]}\end{array}$ & & & & \\
\hline $\begin{array}{l}\text { \# Armenian school buildings/Muslim in } 1893 \\
\text { in non-central kaza/sancak }\end{array}$ & & & 44.478 & 43.299 & & & & \\
\hline & & & {$[29.630]$} & $\begin{array}{l}43.299 \\
{[28.728]}\end{array}$ & & & & \\
\hline in central kaza/sancak & & & $\begin{array}{c}135.414 * * * \\
{[46.825]}\end{array}$ & $\begin{array}{c}135.375^{* * *} \\
{[46.113]}\end{array}$ & & & & \\
\hline \multicolumn{9}{|l|}{ \# Greek school buildings/Muslim in 1893} \\
\hline in non-central kaza/sancak & & & $\begin{array}{l}-0.308 \\
{[0.366]}\end{array}$ & $\begin{array}{l}-0.362 \\
{[0.347]}\end{array}$ & & & & \\
\hline in central kaza/sancak & & & 23.156 & 25.131 & & & & \\
\hline & & & {$[17.821]$} & [20.584] & & & & \\
\hline Central kaza/sancak & & & $\begin{array}{c}0.015^{* * *} \\
{[0.005]}\end{array}$ & $\begin{array}{l}0.007 \\
{[0.005]}\end{array}$ & & & & \\
\hline Observations & 757 & 757 & 757 & 757 & 757 & 757 & 757 & 757 \\
\hline Baseline Controls & $\checkmark$ & $\checkmark$ & $\checkmark$ & $\checkmark$ & $\checkmark$ & $\checkmark$ & $\checkmark$ & $\checkmark$ \\
\hline Subregion FE & $\checkmark$ & $\checkmark$ & $\checkmark$ & $\checkmark$ & $\checkmark$ & $\checkmark$ & $\checkmark$ & $\checkmark$ \\
\hline Hansen J statistic p-value & & & & & & 0.507 & & \\
\hline \multirow{4}{*}{ Kleibergen-Paap F-statistic } & & & & & & 13.935 & & 20.246 \\
\hline & (1) & $(2)$ & $(3)$ & $(4)$ & $(5)$ & (6) & $(7)$ & $(8)$ \\
\hline & OLS & OLS & OLS & OLS & OLS & IV-GMM & OLS & IV-GMM \\
\hline & \multicolumn{8}{|c|}{ PANEL B: University Completion in 2000} \\
\hline Armenian population share, 1893 & $\begin{array}{c}0.027^{* * *} \\
{[0.008]}\end{array}$ & $\begin{array}{c}0.017^{* *} \\
{[0.007]}\end{array}$ & $\begin{array}{c}0.011 \\
{[0.009]}\end{array}$ & $\begin{array}{c}0.006 \\
{[0.008]}\end{array}$ & $\begin{array}{c}0.026^{* * *} \\
{[0.008]}\end{array}$ & $\begin{array}{c}0.073^{* * *} \\
{[0.027]}\end{array}$ & & \\
\hline Greek population share, 1893 & $\begin{array}{c}0.045^{* * *} \\
{[0.010]}\end{array}$ & $\begin{array}{c}0.030^{* * *} \\
{[0.011]}\end{array}$ & $\begin{array}{c}0.041^{* * *} * \\
{[0.013]}\end{array}$ & $\begin{array}{c}0.029^{* *} \\
{[0.013]}\end{array}$ & & & $\begin{array}{c}0.045^{* * *} \\
{[0.010]}\end{array}$ & $\begin{array}{c}0.164^{* * *} \\
{[0.052]}\end{array}$ \\
\hline Literacy rate in 1927 & & $\begin{array}{c}0.139^{* * *} \\
{[0.024]}\end{array}$ & & $\begin{array}{c}0.131 * * * \\
{[0.023]}\end{array}$ & & & & \\
\hline Pop. share of age $<13$ in 1927 & & $\begin{array}{l}-0.032 \\
{[0.033]}\end{array}$ & & $\begin{array}{l}-0.025 \\
{[0.033]}\end{array}$ & & & & \\
\hline Female-male ratio in 1927 & & $\begin{array}{l}-0.003 \\
{[0.009]}\end{array}$ & & $\begin{array}{l}-0.005 \\
{[0.010]}\end{array}$ & & & & \\
\hline \# Armenian school buildings/Muslim in 1893 & & & & & & & & \\
\hline in non-central kaza/sancak & & & $\begin{array}{l}10.319 \\
6.964]\end{array}$ & $\begin{array}{l}10.068 \\
{[6.893]}\end{array}$ & & & & \\
\hline in central kaza/sancak & & & $\begin{array}{c}38.123^{* * *} \\
{[12.950]}\end{array}$ & $\begin{array}{c}37.476^{* * *} \\
{[11.900]}\end{array}$ & & & & \\
\hline \# Greek school buildings/Muslim in 1893 & & & & & & & & \\
\hline in non-central kaza/sancak & & & $\begin{array}{l}-0.189 \\
{[0.128]}\end{array}$ & $\begin{array}{c}-0.217^{*} \\
{[0.120]}\end{array}$ & & & & \\
\hline in central kaza/sancak & & & $\begin{array}{c}2.377 \\
{[5.622]}\end{array}$ & $\begin{array}{c}3.064 \\
{[5.990]}\end{array}$ & & & & \\
\hline Central kaza/sancak & & & $\begin{array}{c}0.005^{* * *} \\
{[0.002]}\end{array}$ & $\begin{array}{c}0.002 \\
{[0.002]}\end{array}$ & & & & \\
\hline Observations & 757 & 757 & 757 & 757 & 757 & 757 & 757 & 757 \\
\hline Baseline Controls & $\checkmark$ & $\checkmark$ & $\checkmark$ & $\checkmark$ & $\checkmark$ & $\checkmark$ & $\checkmark$ & $\checkmark$ \\
\hline Subregion FE & $\checkmark$ & $\checkmark$ & $\checkmark$ & $\checkmark$ & $\checkmark$ & $\checkmark$ & $\checkmark$ & $\checkmark$ \\
\hline Hansen J statistic p-value & & & & & & 0.699 & & \\
\hline Kleibergen-Paap F-statistic & & & & & & 13.935 & & 20.246 \\
\hline
\end{tabular}

Notes: This table presents results from the district level regressions of education outcomes (High School and University Completion rates in 2000) on historical minority shares, literacy rates in 1927 and the number of minority school buildings per Muslim in 1893, controlling for past population density, geographical baselines controls, and subregion fixed effects. The estimated effect associated with increasing minority share from the tenth to the ninetieth percentile of its cross-district distribution is expressed in terms of percentage points change in the share who successfully completed high school (Panel A) and university (Panel B). In IV regressions for Greeks, Greek share is instrumented by the number of ancient Greek sites within $40 \mathrm{~km}$ radius of the district. In IV regressions for Armenians, Armenian share is instrumented by distances to Van and Sis as two of the ancient Armenian kingdoms' capitals. Robust standard errors, clustered at the level of modern Turkish province (il), are reported in square brackets. *** denotes statistical significance at the 1 percent level, ** at $0^{\text {he }} 5$ percent level, and * at the 10 percent level. 
urban centers of the Empire compared to rural places where settlements are more dispersed and segregated. Thus, one would expect human capital spillovers to be stronger in more central urban locations. ${ }^{83}$ In column (3), we capture the effect of Armenian and Greek schools per Muslim in central and non-central locations on contemporary educational attainment. As expected, minority schools per Muslim enter positively in central locations. Higher Armenian schools per Muslim in 1893 positively and significantly predict education attainment in 2000. Although, the sign of the Greek schools per Muslim is also positive, it is not precisely estimated. ${ }^{84}$ In column (4), we include both minority buildings per Muslim and 1927 literacy rates into the specification. The association between historical minority shares and current education outcomes is much more diminished now. For instance, in column (4) of Panel A, the Armenian and Greek share coefficients are reduced by 63 and 50 percent, respectively, compared to column (1), and both lose statistical significance at the conventional levels.

Finally, in columns (5) to (8), we repeat the OLS regressions establishing positive correlations between Ottoman minorities and modern education outcomes with IV analysis. Previous results carry over. ${ }^{85}$

In sum, the evidence from this subsection suggests that the presence of historical Ottoman Armenian and Greek minorities positively impacted local human capital accumulation for the coinhabiting Muslims, and such positive spillovers persist to date influencing contemporary education outcomes.

\subsection{Confiscation of Minority Assets and the Rise of Muslim Capital}

After the Armenian deportations and the Greek-Turkish Population Exchange, some of the properties and the productive assets, such as land plots, shops and factories, that Armenians and Greeks had to leave behind, were plundered by the local residents or captured by the influential elites of the region. In most part though, these properties were confiscated by the state and were eventually

\footnotetext{
${ }^{83}$ Indeed, a series of studies show how cities can help disseminate knowledge (Glaeser et al., 1995; Gennaioli et al., 2013; Moretti, 2004)

${ }^{84}$ This could be due to the fact that minority building collection project is an on-going project, and at the moment, the data for Greek buildings are more incomplete than the data for Armenian buildings.

${ }^{85}$ We omit literacy rate and other demographic controls for the year 1927 as well as Greek and Armenian school buildings from the IV regressions since we do not have appropriate instruments for these endogenous regressors.
} 
sold to the public through auctions, most of the time for way below their real value (Üngör and Polatel, 2011)..$^{86}$

Using a simple framework provided in the Appendix A, we demonstrate that, under a set of reasonable scenarios regarding the post-expulsion transfer of minority assets among the remaining local population and the potential immigrants that arrive, asset concentration in a region (measured as a Gini index for asset holdings) increases with (i) the share of minorities in the population and (ii) the level of minority assets per capita. If, as predicted by the model, following the deportations and the population exchange, asset concentration was indeed more pronounced in regions with higher historical share of Armenians and Greeks, then we should see the impact of these historical shocks to persist or perhaps even become magnified over time. We argue that unequal capture of minority assets not only led to greater asset and wealth disparity among remaining Muslims, but it also facilitated investment in physical capital by the newly emerging Muslim bourgeoisie, and consequently, gave those regions with greater historical minority presence an advantage in establishing more viable businesses and larger scale industries over the early years of the Turkish Republic, which persists to date.

The goal of this section is to take this hypothesis to data. Using district-level information on land holdings of households in 1997, ${ }^{87}$ we investigate whether the expulsion of Armenian and Greek minorities had any persistent effect on concentration of land holdings which we argue is a proxy for

\footnotetext{
${ }^{86}$ On 27 September 1915, Talaat Pasha, then the Minister of Interior and the Minister of Finance of the government, drafted a "temporary law" titled "The law about the abandoned properties, debts and credits of the population who were sent elsewhere". With the directive of this law, special commissions known as the "Abandoned Property Commissions" (Emval-i Metruke Idare Komisyonları) and the "Liquidation Commissions" (Tasfiye Komisyonu) were established. These commissions were tasked with collecting detailed information about the assets of the deportees and assessing their value. Later on, the post-WWI parliament rejected the deportation and the abandoned properties laws as a violation of the Ottoman constitution. In 1920, the Istanbul Government ruled by Ali Riza ordered by decree that the Armenian properties that were liquidated through war-time regulations should be returned to their owners. However, over the period 1922-1925, a series of laws, passed first by the Ankara government of the Turkish national independence movement and then by the parliament of the newly established Turkish Republic, re-instituted the legal foundation for the liquidation and redistribution of the minority assets (Üngör and Polatel, 2011).

${ }^{87}$ With this information, we generate a land holdings concentration variable that is an approximation of a Gini index applied to the size distribution of land plots owned by households.
} 
concentration of asset holdings and wealth. ${ }^{88}$ We combine these data with the data on minority buildings per 1935 population to proxy for per person assets left behind by the minorities. ${ }^{89}$

Table 13 presents the results. The first prediction of our model is that, other things equal, in regions where minority communities were richer, we should observe greater asset concentration. Accordingly, in the first column we estimate the relationship between historical minority buildings per 1935 population and the asset concentration index for land holdings by households (conditional on our baseline controls). Although, historical Armenian buildings per 1935 population significantly and positively predict land concentration in 1997, Greek buildings have no effect. ${ }^{90}$ One concern here is omitted variable bias. The amount of historical minority buildings strongly correlate with minority population shares, which itself according to the second result from our model should have a positive effect on post-expulsion asset concentration. For these reasons, in column (2), we include the historical minority shares directly in the regression equation. Consistently with the predictions, both historical Armenian and Greek shares predict land concentration in 1997 positively, and the magnitude on the Armenian buildings coefficient is reduced. In contrast to Armenian buildings, Greek buildings correlate negatively with land concentration. This correlation is not significant at conventional levels, but certainly stronger than in column (1). ${ }^{91}$ In columns (3) to (6), we replicate the OLS regressions of land concentration on minority shares with the IV approach, and the previous conclusions carry over. ${ }^{92}$ This suggests that both Armenian and Greek presence at the end of the 19th century contributed to asset concentration in the early years of the Turkish Republic, and this effect persists to date.

\footnotetext{
${ }^{88}$ Clearly, the ideal way to test our asset concentration hypothesis would be to use historical data on the value of assets held by minorities and the Muslim population at the regional level and how they were distributed before and after the expulsions. Such data are unfortunately not available. We also do not have data on private property. Systematic records of confiscated properties and how they were distributed among the local Muslims are, to our knowledge, also not available to researchers. Therefore we use the number of community buildings as a rough proxy for how well off minorities were before the expulsions.

${ }^{89}$ Minority buildings data are from the Hrant Dink Foundation, measured as of 1912. In addition to school buildings, the variable records the number of churches, monasteries, chapels, hospitals and cemeteries that used to belong to Armenian and Greek communities. We normalize the number of minority buildings by the 1935 district population instead of the 1927 (the first census of the Turkish Republic) so that enough time has elapsed for the first wave of post-expulsion resettlements of Muslim immigrants and reallocation of minority property to have taken place. We do not choose later years because otherwise the population figures would be less representative of the Muslim population that was directly involved as beneficiaries in the initial capture and redistribution of the minority assets.

${ }^{90}$ It is important to note that the historical buildings data for Greeks are rather incomplete.

${ }^{91}$ It is not possible to say if this negative relationship reflects the difference between how the asset capture process and the subsequent redistribution of minority assets unfolded for Greeks compared to Armenians, or it is just an artifact of the fact that data on Greek buildings are less complete.

${ }^{92}$ We do not have separate instruments for minority buildings and therefore cannot include them in our IV analysis.
} 
TABLE 13: Minorities and their buildings: Implications for Contemporary Wealth Concentration

\begin{tabular}{|c|c|c|c|c|c|c|}
\hline & $\begin{array}{c}(1) \\
\text { OLS }\end{array}$ & $\begin{array}{l}(2) \\
\text { OLS }\end{array}$ & $\begin{array}{c}(3) \\
\text { OLS }\end{array}$ & $\begin{array}{c}(4) \\
\text { IV-GMM }\end{array}$ & $\begin{array}{l}(5) \\
\text { OLS }\end{array}$ & $\begin{array}{c}(6) \\
\text { IV-GMM }\end{array}$ \\
\hline & \multicolumn{6}{|c|}{ Land Holdings Concentration in 1997} \\
\hline Historical Armenian buildings per 1935 population & $\begin{array}{c}41.866^{* * *} \\
{[15.054]}\end{array}$ & $\begin{array}{c}33.615^{* *} \\
{[14.768]}\end{array}$ & & & & \\
\hline Historical Greek buildings per 1935 population & $\begin{array}{l}-0.216 \\
{[4.580]}\end{array}$ & $\begin{array}{l}-6.956 \\
{[4.729]}\end{array}$ & & & & \\
\hline Armenian population share, 1893 & & $\begin{array}{c}0.106^{* *} \\
{[0.042]}\end{array}$ & $\begin{array}{c}0.124^{* * *} \\
{[0.045]}\end{array}$ & $\begin{array}{c}0.304^{* *} \\
{[0.133]}\end{array}$ & & \\
\hline Greek population share, 1893 & & $\begin{array}{c}0.121^{* * *} \\
{[0.033]}\end{array}$ & & & $\begin{array}{c}0.101^{* * * *} \\
{[0.032]}\end{array}$ & $\begin{array}{c}0.769^{* * *} \\
{[0.247]}\end{array}$ \\
\hline Observations & 751 & 751 & 751 & 751 & 751 & 751 \\
\hline Baseline controls & $\checkmark$ & $\checkmark$ & $\checkmark$ & $\checkmark$ & $\checkmark$ & $\checkmark$ \\
\hline Subregion FE & $\checkmark$ & $\checkmark$ & $\checkmark$ & $\checkmark$ & $\checkmark$ & $\checkmark$ \\
\hline Effect of increasing Armenian share & & & & $5.849^{* *}$ & & - \\
\hline from the 10 -th to the 90 -th percentile & & & & {$[2.551]$} & & - \\
\hline Effect of increasing Greek share & & & & - & & $19.776^{* * *}$ \\
\hline from the 10 -th to the 90 -th percentile & & & & - & & {$[6.352]$} \\
\hline Hansen J statistic p-value & & & & 0.121 & & - \\
\hline Kleibergen-Paap F-statistic & & & & 14.321 & & 19.813 \\
\hline
\end{tabular}

Notes: This table presents results from the district level regressions of Land Holdings Concentration in 1997 on historical minority shares, and the number of minority buildings per 1935 population, controlling for past population density, geographical baselines controls, and subregion fixed effects. The estimated effect associated with increasing minority share from the tenth to the ninetieth percentile of its cross-district distribution is expressed in terms of percent change in the Land Holdings Concentration in 1997 variable. In IV regressions for Greeks, Greek share is instrumented by the number of ancient Greek sites within $40 \mathrm{~km}$ radius of the district. In IV regressions for Armenians, Armenian share is instrumented by distances to Van and Sis as two of the ancient Armenian kingdoms' capitals. Robust standard errors, clustered at the level of modern Turkish province $(i l)$, are reported in square brackets. *** denotes statistical significance at the 1 percent level, ** at the 5 percent level, and $*$ at the 10 percent level.

Overall, the results from Table 13 are supportive of our asset transfer hypothesis. One reason why historical minority shares predict land holdings concentration in 1997 is that minorities were presumably holding a disproportionately larger share of land vis-a-vis their representation in the population. As our simple model illustrates, the resulting historical inequality in land holdings persisted over time due to the unequal redistribution of confiscated lands and other property after the expulsions. We further argue that concentration of land holdings should be positively correlated with investment in physical capital and hence with economic activity. This correlation could be due to two main reasons that are not mutually exclusive. One reason could be the direct effect of concentration in land holdings and other valuable property on wealth concentration which in turn might have facilitated investment, especially during the early stages of Turkish economic development when capital was scarce and financing constraints were more binding. The second reason could be that land concentration also mirrors the amount of productive assets (shops, factories, etc.) in high minority regions. If, as we previously argued, these assets 
remained concentrated in the hands of a few influential households it might eventually result in greater concentration of land holdings as well. Consequently, land concentration, as a proxy for expropriated physical capital, would predict higher economic activity, since it might have given high minority regions a head start position in the process of industrialization and regional development. We turn to this in the next subsection.

\subsection{Relevance of Intermediating Channels in Explaining Average Luminosity}

In Table 14, we evaluate the relevance of intermediating human capital and asset channels in explaining contemporary economic activity measured by luminosity. ${ }^{93}$ We regress average luminosity on minority shares, educational attainment and land concentration measures to see the extent to which the positive minority influence on economic development could be explained through accumulated human capital and the contribution of minority assets to wealth concentration.

TABLE 14: Relevance of Intermediating Channels in Explaining Average Luminosity, 2007-2013

\begin{tabular}{|c|c|c|c|c|c|c|c|c|}
\hline & $\begin{array}{c}(1) \\
\text { OLS }\end{array}$ & $\begin{array}{c}(2) \\
\text { OLS }\end{array}$ & $\begin{array}{c}(3) \\
\text { OLS }\end{array}$ & $\begin{array}{c}(4) \\
\text { OLS }\end{array}$ & $\begin{array}{c}(5) \\
\text { OLS }\end{array}$ & $\begin{array}{c}(6) \\
\text { OLS }\end{array}$ & $\begin{array}{c}(7) \\
\text { OLS }\end{array}$ & $\begin{array}{c}(8) \\
\text { OLS }\end{array}$ \\
\hline & \multicolumn{8}{|c|}{ Log(Average Luminosity 2007-2013) } \\
\hline Armenian population share, 1893 & $\begin{array}{c}1.073^{* * *} \\
{[0.304]}\end{array}$ & $\begin{array}{c}0.909^{* * *} \\
{[0.297]}\end{array}$ & $\begin{array}{c}0.928^{* * *} \\
{[0.290]}\end{array}$ & $\begin{array}{c}0.778^{* * *} \\
{[0.282]}\end{array}$ & $\begin{array}{c}0.411 \\
{[0.287]}\end{array}$ & $\begin{array}{c}0.564^{* *} \\
{[0.278]}\end{array}$ & $\begin{array}{l}0.550^{*} \\
{[0.298]}\end{array}$ & $\begin{array}{c}0.710^{* *} \\
{[0.287]}\end{array}$ \\
\hline Greek population share, 1893 & $\begin{array}{c}1.294^{* * *} \\
{[0.275]}\end{array}$ & $\begin{array}{c}1.071^{* * *} \\
{[0.291]}\end{array}$ & $\begin{array}{c}1.169^{* * *} \\
{[0.267]}\end{array}$ & $\begin{array}{c}0.963^{* * *} \\
{[0.283]}\end{array}$ & $\begin{array}{c}0.626^{* *} \\
{[0.247]}\end{array}$ & $\begin{array}{c}0.524^{* *} \\
{[0.238]}\end{array}$ & $\begin{array}{c}0.759^{* * *} \\
{[0.246]}\end{array}$ & $\begin{array}{c}0.651^{* *} \\
{[0.244]}\end{array}$ \\
\hline Literacy rate in 1927 & & $\begin{array}{c}2.532^{* * *} \\
{[0.872]}\end{array}$ & & $\begin{array}{c}2.403^{* * *} \\
{[0.834]}\end{array}$ & $\begin{array}{c}0.531 \\
{[0.664]}\end{array}$ & $\begin{array}{c}0.344 \\
{[0.591]}\end{array}$ & & \\
\hline High school completion rate in 2000 & & & & & $\begin{array}{c}4.905^{* * *} \\
{[0.474]}\end{array}$ & & $\begin{array}{c}5.111^{* * *} \\
{[0.520]}\end{array}$ & \\
\hline University completion rate in 2000 & & & & & & $\begin{array}{c}14.422^{* * *} \\
{[1.695]}\end{array}$ & & $\begin{array}{c}14.831^{* * *} \\
{[1.807]}\end{array}$ \\
\hline Land Holdings Concentration in 1997 & & & $\begin{array}{c}1.207 * * * \\
{[0.366]}\end{array}$ & $\begin{array}{c}1.157^{* * *} \\
{[0.354]}\end{array}$ & $\begin{array}{c}1.048^{* * *} \\
{[0.322]}\end{array}$ & $\begin{array}{c}1.118^{* * *} \\
{[0.337]}\end{array}$ & & \\
\hline Observations & 753 & 753 & 753 & 753 & 753 & 753 & 753 & 753 \\
\hline Baseline controls & $\checkmark$ & $\checkmark$ & $\checkmark$ & $\checkmark$ & $\checkmark$ & $\checkmark$ & $\checkmark$ & $\checkmark$ \\
\hline Subregion FE & $\checkmark$ & $\checkmark$ & $\checkmark$ & $\checkmark$ & $\checkmark$ & $\checkmark$ & $\checkmark$ & $\checkmark$ \\
\hline
\end{tabular}

Notes: This table presents results from the district level regressions of average luminosity between 2007-2013 on historical minority shares, educational attainment variables, and land concentration in 1997, controlling for past population density in 1927, geographical baselines controls, and subregion fixed effects. Robust standard errors, clustered at the level of modern Turkish province (il), are reported in square brackets. *** denotes statistical significance at the 1 percent level, $* *$ at the 5 percent level, and $*$ at the 10 percent level.

For comparison purposes, column (1) of Table 14 shows the regression of luminosity on minority shares. In column (2), when we additionally control for literacy rates in 1927, the

\footnotetext{
${ }^{93}$ Educational attainment and land concentration measures are reported for the years 2000 and 1997 respectively. Therefore, to alleviate reverse causality issues we use the average of district level luminosity between 2007-2013 instead of the year 2000 .
} 
magnitude of the minority share coefficients goes down, although they are still significant at the 1 percent level. In column (3), instead, we control for land holdings concentration in 1997. Although, the minority share coefficients are again reduced compared to column (1), the reduction is less than that in column (2), suggesting that the intermediating effect on economic activity of literacy rates in 1927 is stronger than that of land concentration. Furthermore, in columns (5) and (6), we additionally control for contemporary educational attainment as high school and university completion rates. In this case, the coefficients on minority shares are less than half of their magnitudes in column (1), and their statistical significance is also reduced. Notice that, in columns (5) and (6), the coefficient on literacy rate in 1927 is insignificant, suggesting that once contemporary education is taken into account literacy rate in 1927 has no effect on modern economic activity. We observe a similar pattern of large reduction in minority coefficients in columns (7) and (8) when we only control for contemporary educational attainment. This suggests that the greatest intermediating effect of historical minority presence on today's economic activity is through their contribution to local human capital. This should not come as a suprise as the neo-classical theory suggests that a positive capital shock (minority asset transfer in our case) should eventually peter out. Although our findings in Table 14 do not necessarily reflect a causal effect, they nonetheless are consistent with a positive minority legacy on subsequent human capital accumulation and economic development.

Lastly, we conduct Sobel-Goodman tests to see whether the reductions in the point estimates of minority shares in Table 14 -when the intermediating channels are controlled for-are statistically significant. The sizes of these so called 'indirect' effects of Armenian and Greek presence on economic activity that go through literacy rate in 1927, high school completion rate in 2000, university completion rate in 2000, and land holdings concentration in 1997 are reported in Table 15 along with their standard errors. ${ }^{94}$ The mediated effects for all four variables are statistically significant at least at the 5 percent level. However, the magnitudes of the intermediating channels vary. The fraction of the total 'Armenian effect' on luminosity that is mediated by land holdings concentration is only 14 percent, while the corresponding fraction is even lower, 10 percent, for Greeks. Importantly, consistent with our conclusions from Table 14, the largest intermediating channels are contemporary

\footnotetext{
${ }^{94}$ We used sgmediation module for STATA to carry out the Sobel-Goodman mediation tests. Reported significance levels are based on bootstrapped standard errors with case resampling (1000 replications).
} 
educational attainment. The greatest mediating variable for the Armenian effect is high school completion rate in 2000 accounting for 49 percent of the total Armenian effect, whereas the greatest mediating variable for the total Greek effect is university completion rate in 2000 accounting for 50 percent. Inversely, university completion rate mediates 34 percent of the total Armenian effect, and the high school completion rate mediates 41 percent of the total Greek effect.

TABle 15: Minority Presence and Average Luminosity: Mediating Role of Human Capital and Asset Transfer Channel in Explaining Contemporary Economic Activity

\begin{tabular}{|c|c|c|c|c|c|}
\hline & & \multicolumn{4}{|c|}{ Mediating Variable } \\
\hline & & Literacy Rate, 1927 & High School, 2000 & University, 2000 & Land Concentration, 1997 \\
\hline \multirow{3}{*}{ Armenian share } & Direct effect & $\begin{array}{c}0.909^{* * *} * \\
{[0.321]}\end{array}$ & $\begin{array}{c}0.551^{* *} \\
{[0.277]}\end{array}$ & $\begin{array}{c}0.711^{* *} \\
{[0.277]}\end{array}$ & $\begin{array}{c}0.928^{* * *} * \\
{[0.308]}\end{array}$ \\
\hline & Mediated effect & $\begin{array}{c}0.165^{* *} \\
{[0.066]}\end{array}$ & $\begin{array}{c}0.523^{* * *} \\
{[0.156]}\end{array}$ & $\begin{array}{c}0.363^{* * *} \\
{[0.119]}\end{array}$ & $\begin{array}{c}0.145^{* *} \\
{[0.069]}\end{array}$ \\
\hline & Fraction of total effect mediated & 0.15 & 0.49 & 0.34 & 0.14 \\
\hline \multirow{3}{*}{ Greek share } & Direct effect & $\begin{array}{c}1.071^{* * *} \\
{[0.268]}\end{array}$ & $\begin{array}{c}0.760^{* * *} \\
{[0.229]}\end{array}$ & $\begin{array}{c}0.652^{* * *} \\
{[0.236]}\end{array}$ & $\begin{array}{c}1.169^{* * *} \\
{[0.251]}\end{array}$ \\
\hline & Mediated effect & $\begin{array}{c}0.223^{* * *} \\
{[0.074]}\end{array}$ & $\begin{array}{c}0.534^{* * *} \\
{[0.138]}\end{array}$ & $\begin{array}{c}0.642^{* * *} \\
{[0.136]}\end{array}$ & $\begin{array}{c}0.125^{* *} \\
{[0.054]}\end{array}$ \\
\hline & Fraction of total effect mediated & 0.17 & 0.41 & 0.50 & 0.10 \\
\hline
\end{tabular}

Notes: This table presents results from the Sobel-Goodman tests on the direct and the mediated effect of Armenian and Greek shares on average luminosity between 2007-2013, controlling for past population density in 1927, geographical baselines controls, and subregion fixed effects. The mediating variables are literacy rate in 1927 , high school completion rate in 2000, university completion rate in 2000 , and land concentration in 1997. Bootstrapped standard errors with case resampling (1000 replications) are reported in square brackets. *** denotes statistical significance at the 1 percent level, ** at the 5 percent level, and ${ }^{*}$ at the 10 percent level.

In sum, our results from this subsection suggest that the historical minority presence contributes to current regional development to a great extent through its legacy on local human capital, and, to a small extent, through its legacy on wealth concentration.

\section{$7 \quad$ A Case Study: Province of Kayseri}

In this section, we offer an overview of the history of Kayseri Province with a focus on the historical role Armenian and Greek minorities played in its socioeconomic life. Using data on location of minority buildings and luminosity, we complement our discussion with empirical evidence on the economic legacy of minorities at the township/village level .

Kayseri Province is an ideal candidate for a case study for several reasons. The primary reason is that among all Turkish provinces, Kayseri has the most complete list of historical Armenian and Greek community buildings as recorded by the TKVE Project. This is crucial since data on historical minority populations are not available at township/village level, and therefore, we need 
to rely on proximity to minority buildings as a proxy for long-term local exposure to Armenian and Greek influence. The second reason is that historically both the Greek and Armenian communities had quite a sizeable representation in Kayseri. Therefore, in Kayseri we are able to exploit withinprovince variation in minority exposure that is reasonably high to conduct a statistically meaningful local analysis for both groups. Since historical homelands of each group are quite distinct, we do not have a similar degree of spatial overlap in many of other provinces. Another advantage of focusing on Kayseri for a case study is that the history of Armenians and Greeks of the region is better documented in secondary sources than for most other provinces in our sample. Finally, an unusually large number of businessmen from Kayseri have received country-wide fame as exceptionally successful entrepreneurs. Also, it is widely acknowledged that Kayseri merchants' adeptness in trade stands out among others from elsewhere in Turkey. Anecdotally, this success has been partly attributed to a strong minority influence on the economic life of Kayseri and on the human capital of its local population. Starting with such strong priors, failing to find a systematic link between the spatial distribution of minorities and luminosity within Kayseri would shed doubt on the presence of localized effects that we want to test in general. Yet, absence of a significant relationship would of course not undermine the broader effects we have already documented by exploiting cross-district variation at the country level.

Kayseri is a province in central Turkey (see Figure S.2 in the Online Appendix) with a current population of 1.25 million. Kayseri has been an ancient settlement as early as the Hittite Empire. ${ }^{95}$ With the rise of Christianity, Kayseri, called Caesarea Cappadociae in Roman, became home to early Christian settlers. ${ }^{96}$ During the Byzantine Empire, it has risen to the status of an important metropolitan see, and served as the residential see of the Eastern Orthodox Church until 1923, as well as the seat of an Armenian diocese with Surp Garabed Monastery as its epicenter. The area was conquered by the Seljuk Turks in the 11th century to be sacked by the Mongols shortly after. It came under total Ottoman control in the 16th century.

Although the presence of Muslim population in the area increased over the centuries, Kayseri has always remained a melting pot where Christians and Muslims thrived together. In the 16th and the 17th centuries, Kayseri had one of the highest non-Muslim concentration in the region

\footnotetext{
${ }^{95}$ E.g. ancient Hittite-Assyrian colony of Kultepe from the 3rd millennium BC is located 20km northeast of the city of Kayseri.

${ }^{96}$ With its own ecclesiastic centre established by St. Basil the Great.
} 
(Kekecoglu, 2007). At the end of the 19th century, one third of the population was Christian (Karpat, 1985). In the 1893 census, total number of Muslims in Kayseri province equaled 120,357, whereas that of Armenians and Greeks equaled 35,819 and 24,895, respectively. Thus, shares of Armenians and Greeks in total population were 20 and 14 percent, respectively.

Historically, Christian minorities played a big role in developing Kayseri's commercial environment, advanced craftsmanship (jewelry, leather, carpets, and textile manufacturing), and entrepreneurial skills of local population. In the 17th century, Kayseri was known in the markets of Amsterdam and Venice for its non-Muslim merchants. They were successful not only in trade but also in manufacturing. For example, around 1856, the textile factory built by Hasirciyan brothers contained 300 weaving stalls (Erkiletlioglu, 2006). In addition, Kayseri has been a historical center of education. It is the site of one of the earliest schools of medicine in the early 13th century, the Giyasiye Şifahiye. Before the foundation of the Turkish Republic, there were 56 institutes of education in Kayseri (Kévorkian, 2011). Some prominent examples of education institutes are Torkomyan Institute from the 16th century, Haygyan Institute (founded around 1800), and Hayguhyan and Aramyan Girls' Colleges (Kévorkian, 2011). Relatedly, Erciyes University in modern Kayseri also descended from schools founded in 1206 and 1956.

Moreover, from a historical perspective, Kayseri is the epitome of a multi-cultural society that flourished economically (Aktan, 1996; Kekecoglu, 2007). The degree of coexistence and interaction between Muslims and non-Muslims was remarkable. For instance, there were several mixed neighborhoods in various towns where Muslims and Christians coexisted peacefully (Aktan, 1996). The commercial relationships between Muslims and non-Muslims were very dynamic. Merchants had their trade and business links, whereas young boys helped their fathers or were apprentices with a skilled artisan. Significantly, the extent of economic integration was such that Muslims and non-Muslims not only traded and interacted on a constant basis, but they also had joint enterprises (Kekecoglu, 2007). ${ }^{97}$

Kayseri also provides a striking example of how confiscation and redistribution of Armenian property facilitated the emergence of a Muslim bourgeoisie in the aftermath of deportations. Part of the abandoned residential property was reallocated to Muslim refugees and immigrants who arrived

\footnotetext{
${ }^{97}$ For example, Parsihoglu Sahbaz ran a joint trading company, called Anadolu Kumpanyasi, together with Bodan, the son of Boyacioglu Karabet, and Migirdic, the son of Tazik. Kazancioglu Haci Agop and Kasagici Haci Efendi were merchant partners (Bayrak, 2003).
} 
from the regions of Eastern Anatolia following the Russian occupation. Part of the valuable goods and property in Armenian shops was used to meet the needs of the army and the local residents, while the rest was auctioned by the Abandoned Properties (Emval-i Metruke) Commission and bought for extremely low prices by Muslim-owned companies that were established during the First World War. ${ }^{98}$ Historical records show that companies that benefited most from this asset transfer were founded by the local elite who were either members of or connected to the Committee of Union and Progress in power (Gözel Durmaz, 2015).

Starting with the early republican period of 1920s, Kayseri has undergone rapid industrialization. It specializes in the manufacture of sugar, cement, textiles, home appliances, and aircraft spare parts. It is also a centre for goldsmiths and carpet manufacturers. Today, Kayseri maintains its economic importance, and is often dubbed as a prime example of the so-called Anatolian Tigers due to its economic growth success since 1980s. It is well-acknowledged for its traders and businessmen, and has produced successful capitalist families, such as Sabanci, Dedeman, Has, Boydak, Hattat, Ozyegin, and Ozilhan, who have become prominent actors in the Turkish economy.

To empirically evaluate the legacy of Armenian and Greek communities in the Province of Kayseri, we carry out a sub-province level analysis. To that end, we rely on the minority community buildings data from TKVE project that we have already employed in Section 6. Given that we do not have minority figures at the township/village level from historical censuses, we proxy the longrun presence of minorities with the number of historical minority buildings within a given radius around a town/village. According to the authors of TKVE Project, the Province of Kayseri has the most completely documented inventory of minority buildings. ${ }^{99}$ This gives us the most reliable sub-province level variation in minority presence we can possibly exploit across townships/villages.

The top and the bottom maps in Figure 13 show the distribution of Armenian and Greek community buildings in the Province of Kayseri, respectively. Although some minority buildings tend to cluster around certain urban centers like the city of Kayseri, there is still substantial variation across the province at large. In the more rural parts of the province, Armenian and Greek

\footnotetext{
${ }^{98}$ Before the war, there were no joint-stock company in Kayseri. Two such companies, Köy Iktisat Bankası and Kayseri Milli Iktisat Anonim Sirketi, were founded during the war and substantially increased their assets due to this capital transfer.

${ }^{99}$ See http://turkiyekulturvarliklari.hrantdink.org/en/kayseri/.
} 
presence does not seem to overlap greatly. Armenians are largely concentrated in the northeast and the south of the province, while the Greeks in the north and the west.
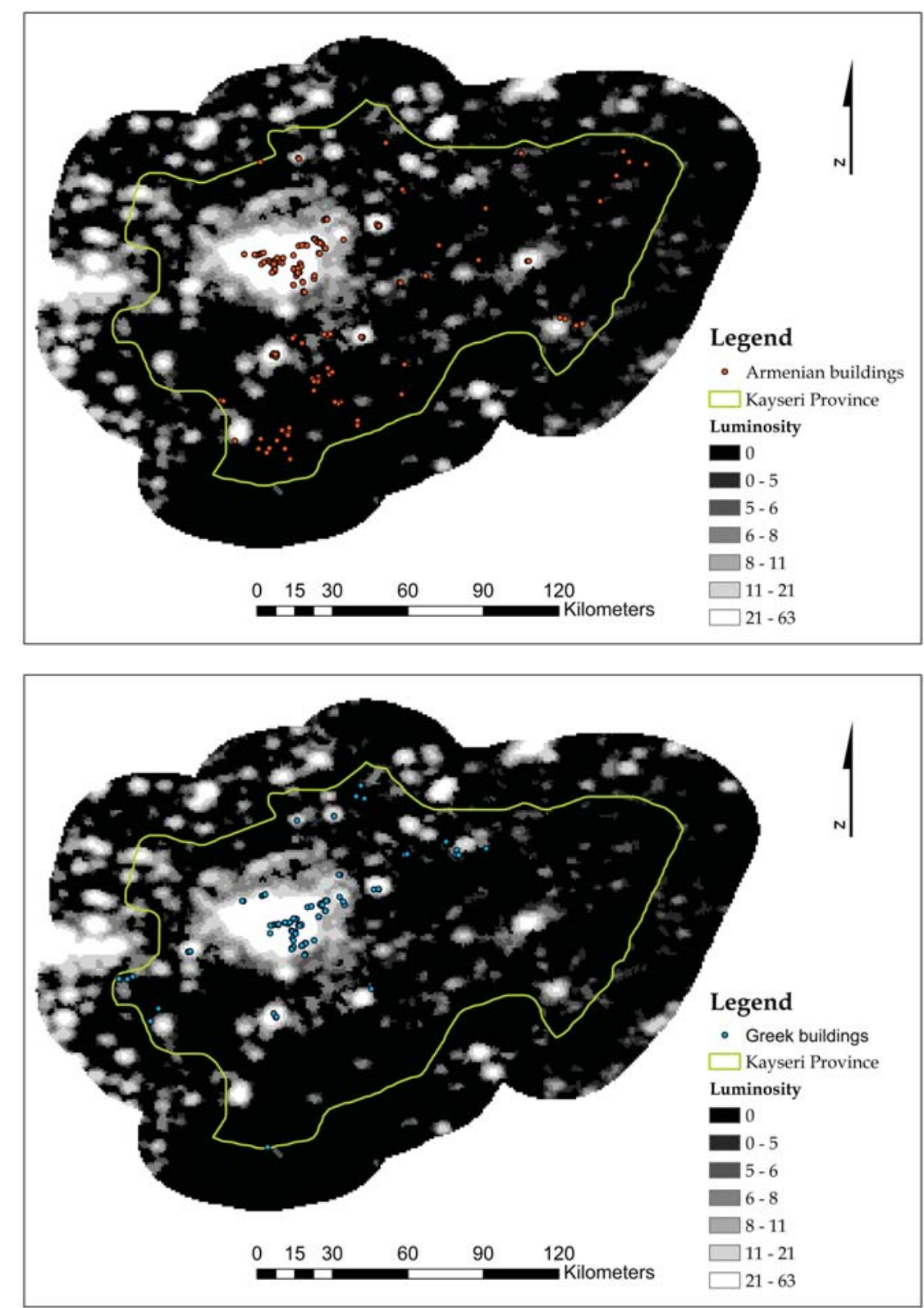

Figure 13: Distribution of Historical Minority Buildings and Luminosity in Kayseri Province

Our unit of analysis is a locality, i.e. either a township or a village. To construct our measures of minority exposure, we compute, for several distance cutoffs between 3 to $50 \mathrm{~km}$, the number of Armenian/Greek buildings that are located within a given distance to the centroid of each locality. We generate our outcome variable similarly by computing average luminosity within 
a given radius around the centroid of a given locality. We regress average luminosity within a given radius around each township/village on the number of minority buildings within a specified radius controlling for subdistrict (bucak) fixed effects. ${ }^{100}$ More specifically, we estimate equations of the form

$$
y_{i}(r)=\alpha_{r, g, b, d}+\beta_{r, g, b, d} N(i, g, b, d)+\delta_{i}+\varepsilon_{i}
$$

where $y_{i}(r)$ is the mean luminosity over the period 1992-2013 averaged over all pixels within a distance of $r=1,2,3,5,10$ kilometers to the locality $i .{ }^{101} N(i, g, b, d)$ denotes the number of community buildings of type $b$ that used to belong to minority group $g$ and lie within a distance of $d \mathrm{~km}$ to locality $i . \delta_{i}$ denote bucak (subdistrict) fixed effects. ${ }^{102}$ For both Armenians and Greeks, we run separate OLS regressions using several combinations of luminosity radius $r$, building type $b$ (all community buildings or just schools) and distance cutoff $d$ to count the number of buildings of a given type. We cluster standard errors at bucak level.

Figures 14 and 15 show coefficient plots from those regressions where $r=5 \mathrm{~km}$ and distance cutoff for minority buildings vary between $3 \mathrm{~km}$ and $50 \mathrm{~km} .{ }^{103}$ Each coefficient corresponds to a different regression and is scaled to show the percentage change in luminosity in response to one additional minority building within a given distance to township/village centroid. We also plot 95 percent confidence intervals for the estimated coefficients. Figure 14 presents our results for local Armenian legacy. Estimates on the left panels are based on all Armenian community buildings, while those presented in the right panels are based on Armenian school buildings only. The sample of analysis on the top panels includes all localities, while the sample used for the bottom panels includes only villages. Findings suggest that, in the Province of Kayseri, townships and villages with greater proximity to historical Armenian buildings are more developed today. Although the results are stronger for the sample of all localities, they are not entirely driven by urban locations and are also significantly positive in the village sample. Consistent with the human capital channel, more school buildings in close proximity are associated with greater light density. Importantly,

\footnotetext{
${ }^{100}$ There are 23 bucaks in the Province of Kayseri.

${ }^{101}$ To be more accurate, we transform the average level of luminosity $\operatorname{lum}_{i}(r)$ such that $y_{i}(r)=\ln (0.01+\operatorname{lum}(r))$.

${ }^{102}$ Since bucak is a very small administrative unit in terms of area, we do not control for micro-geography.

${ }^{103}$ Results with average luminosity within 3 and $10 \mathrm{~km}$ are in Figures S.3 and S.4 in the Online Appendix, and are similar. Also note that the results with average luminosity and minority buildings within 1 and $2 \mathrm{~km}$ are qualitatively similar.
} 

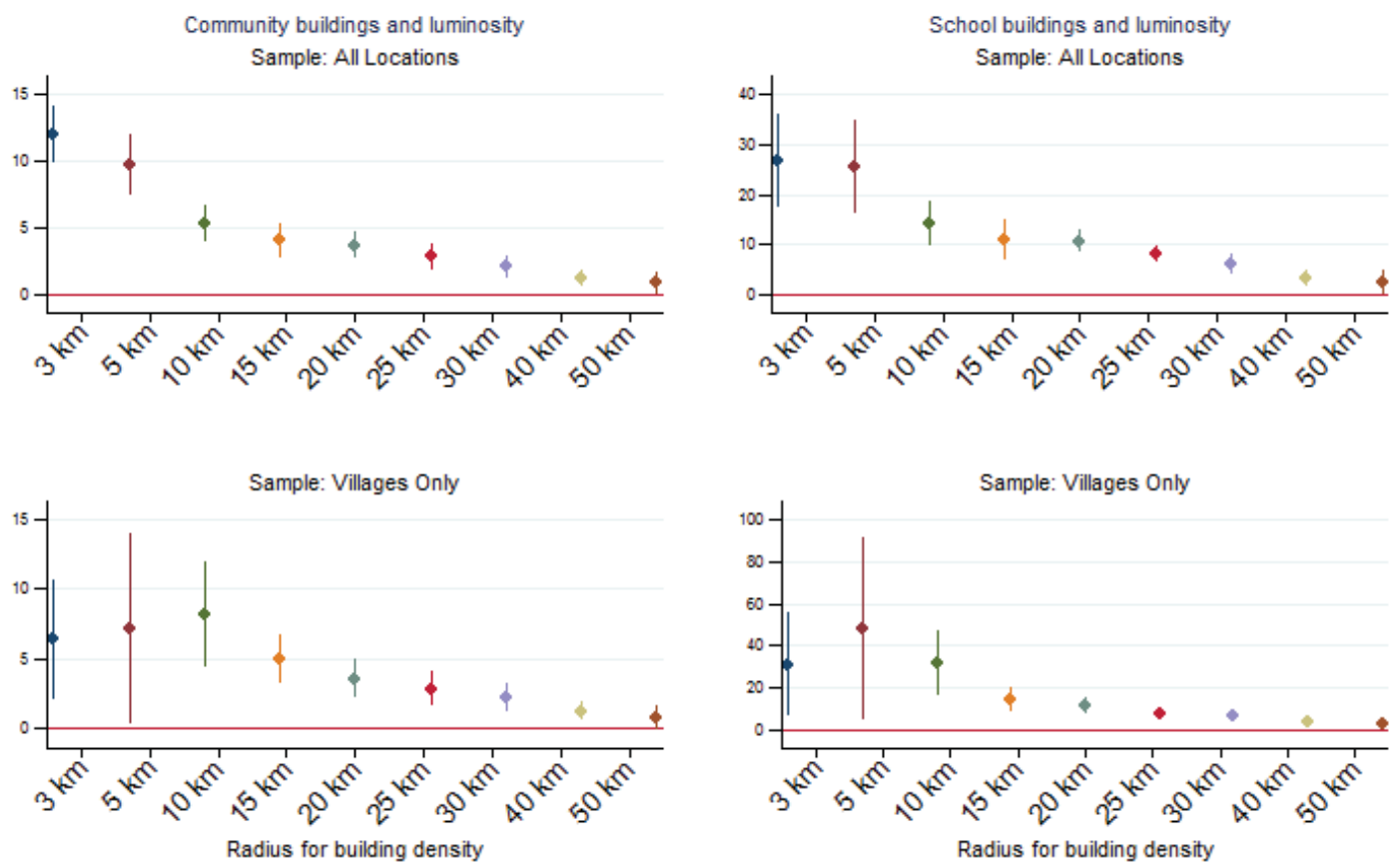

Note: All locations sample contains 443 observations. Village sample contains 395 observations. Plotted coefficients show the percentage change in average luminosity in response to one more building within a given distance to town/village centroid. Regressions include subdistrict (bucak) fixed effects. Standard errors are clustered at subdistrict level. $95 \%$ confidence intervals are drawn for each point estimate.

Figure 14: Historical Armenian Buildings and Economic Activity in Kayseri Province

the estimated coefficients for school buildings are larger than the overall effects we find using all community buildings. For example, one additional Armenian school building within 3km implies about $26.6 \%$ increase in average luminosity, while the corresponding number is about $12 \%$ for all Armenian community buildings. For villages, this difference is starker. In the village sample, one additional Armenian school building within 3km is accompanied by an increase of about $31 \%$ in average luminosity, while the corresponding magnitude is only $6.3 \%$ when we use all Armenian community buildings. Importantly, the marginal influence of minority buildings on local luminosity tends diminish in size as we move away from the center of localities, suggesting that not only the number of buildings surrounding the locality but also their proximity matter. Figure 15 presents the same set of results for Greek community buildings. Like for Armenians, locations with greater long-term Greek presence appear to be systematically more developed today. Yet, consistent with the human capital channel, the effect of school buildings is larger than that of all community buildings. In the sample of all localities, having one additional Greek school building within 3km 

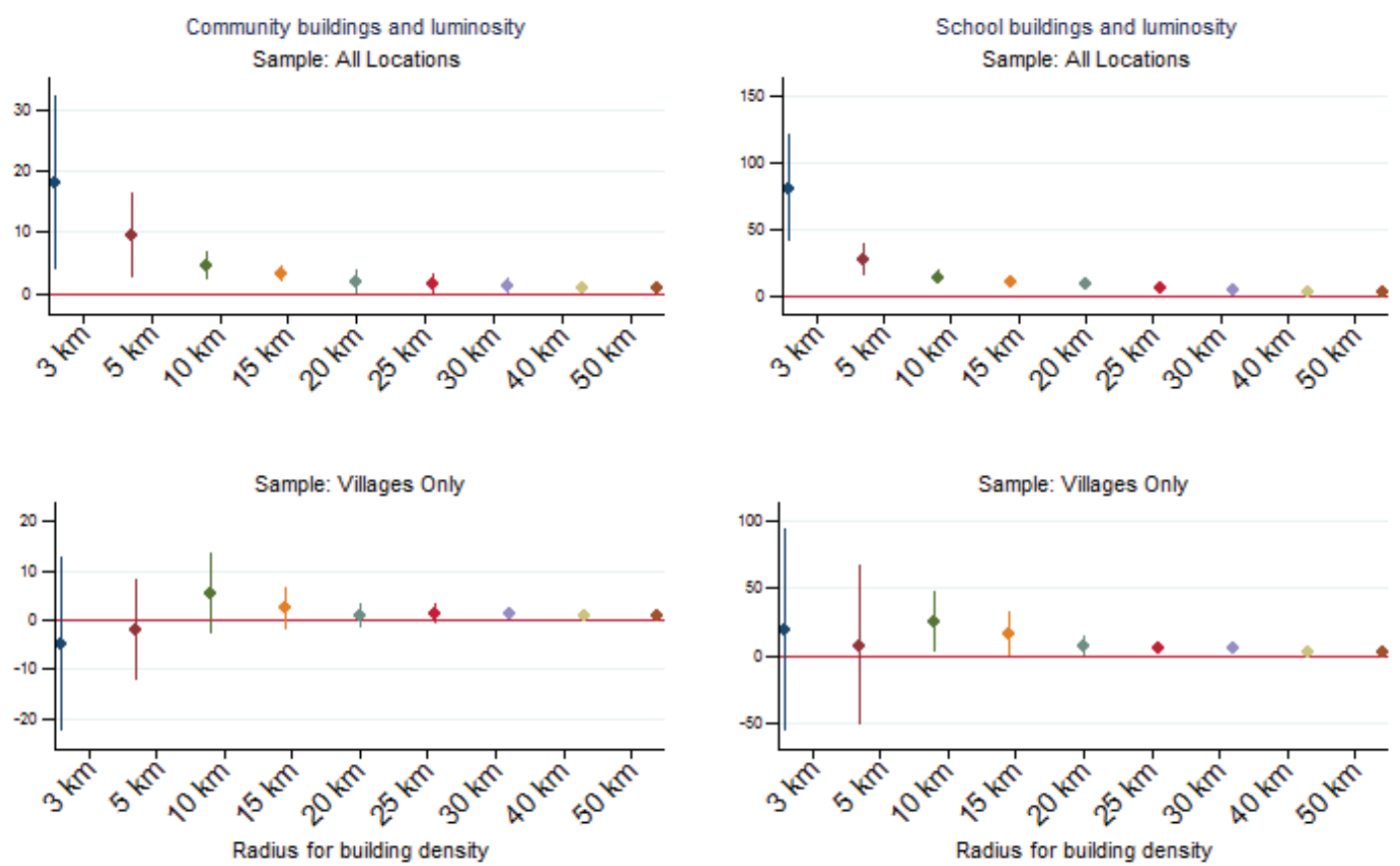

Note: All locations sample contains 443 observations. Village sample contains 395 observations. Plotted coefficients show the percentage change in average luminosity in response to one more building within a given distance to town/village centroid. Regressions include subdistrict (bucak) fixed effects. Standard errors are clustered at subdistrict level. $95 \%$ confidence intervals are drawn for each point estimate.

FiguRE 15: Historical Greek Buildings and Economic Activity in Kayseri Province

corresponds to an increase of about $80.7 \%$ in average luminosity, while the same figure is about $18 \%$ for all Greek buildings. In the village sample, we do not find much significance for all community buildings, although our results are somewhat more significant and generally larger in magnitude for Greek schools. Taken together Greek influence on development seem to be largely driven by more urbanized localities. This result is not very surprising since a large majority of Greek buildings in Kayseri are concentrated around the city of Kayseri and nearby townships rather than smaller villages (see the maps in Figure 13).

Lastly, for the subsample of townships only, we have data on educational breakdown of the population in 2012.104 Thus, to specifically look into the human capital legacy of minorities, we regress the share of township population with high school degree or above on the number of minority buildings within a specified radius controlling for subdistrict (bucak) fixed effects. ${ }^{105}$

\footnotetext{
${ }^{104}$ This corresponds to 48 observations.

${ }^{105}$ When we run the same set of regressions without subdistrict fixed effects (due to degrees of freedom concerns), the results are unaltered.
} 
Figure 16 presents the results for Armenian and Greek buildings in the top and the bottom panels,

\section{Dependent Variable: Share of 6+ population with high school degree or above}

Sample: Townships in Kayseri
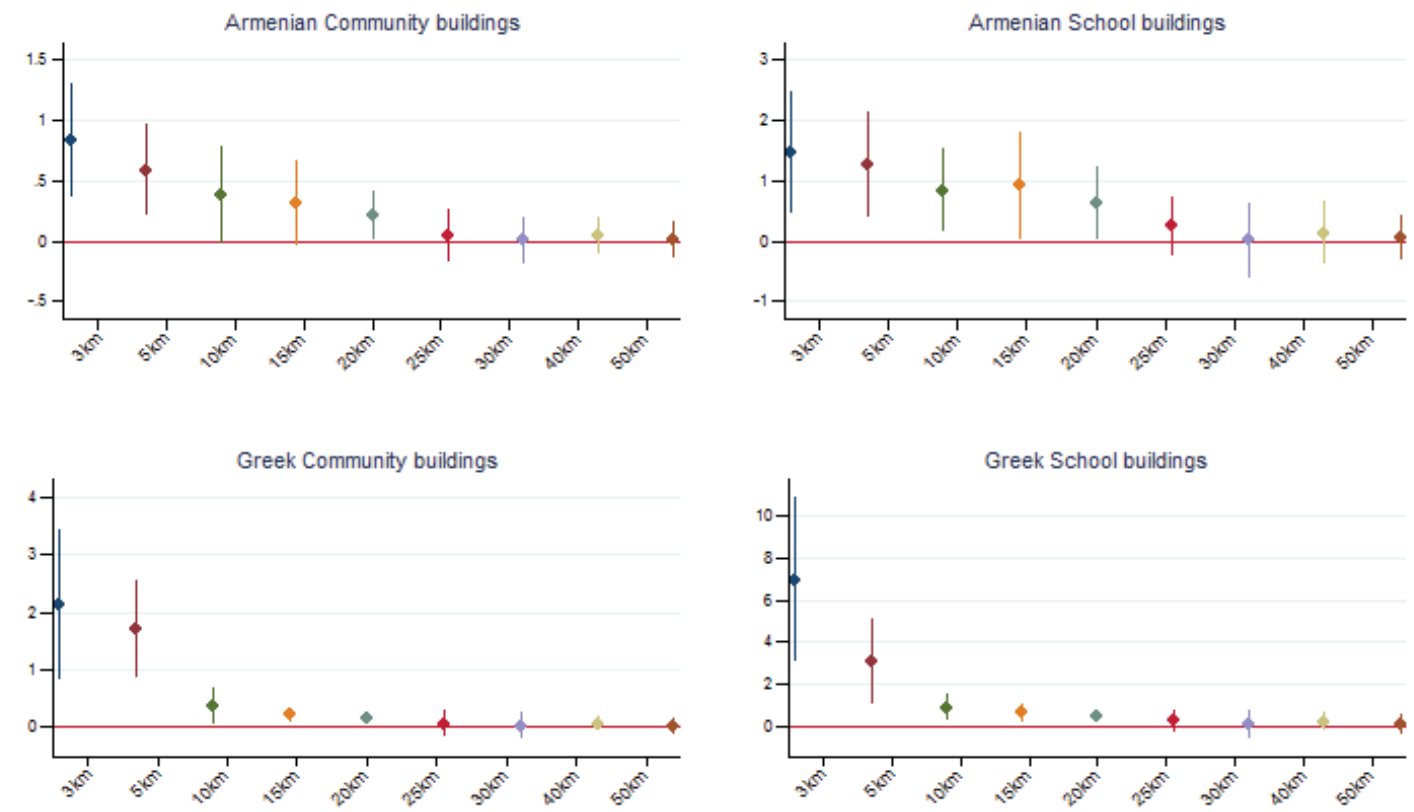

Note: Sample contains 48 townships. Plotted coefficients show the percentage point change in the

fraction of population in response to one more minority building within a given distance to township centroid. Regressions include subdistrict (bucak) fixed effects. Standard errors are clustered at subdistrict level. $95 \%$ confidence intervals are drawn for each point estimate.

Figure 16: Historical Minority Buildings and Educational Attainment in Kayseri Province

respectively. While left panel includes all community buildings, right panel includes school buildings only. Overall, the results are consistent with the human capital channel and confirm the legacy of minorities on local human capital. One additional Armenian community building within $3 \mathrm{~km}$ of townships is associated with a 0.8 percentage point increase in the share of high school or above graduates. Instead, the corresponding increase is about 1.5 percentage points for Armenian school buildings, further supporting the human capital channel. On the other hand, one additional Greek community building corresponds to a 2.1 percentage points increase in the share of high school or above graduates, while this figure is about 7 percentage points for Greek school buildings. Thus, we conclude that historical presence of minorities is associated with higher local human capital today, and this association is stronger in places with greater minority human capital exposure. ${ }^{106}$

\footnotetext{
${ }^{106}$ Also, we find that the role of proximity to minority buildings in explaining luminosity is reduced when we control for the share of high school or above graduates (in regressions not shown here), suggesting that the influence of minorities on development is mediated through human capital.
} 


\section{Concluding Remarks}

This paper studies the long-run economic legacy of highly-skilled minorities and the channels of persistence, long after those minorities are expelled en masse. We offer evidence that the centurieslong presence of the two largest non-Muslim minorities of the Ottoman Empire, Armenians and Greeks, has significantly shaped the regional patterns of Turkish development. In particular, we find that, in modern day Turkey, districts with greater presence of historical Armenians and Greeks about a century ago are more densely populated, more urbanized, and more developed today.

We provide evidence on the channels through which Armenian and Greek presence might have shaped the regional outcomes. In particular, we show that Muslim residents of districts with greater exposure to Greek and Armenian presence were more educated in the past and are more educated today. This result might be a systematic indication of the positive externalities created by Armenian and Greek human capital on Muslim co-residents in the same localities. We also explore the intermediating role of minority asset transfer to remaining population, and show that the asset transfer channel appears less important for current development.

Taken together, our results bear significance beyond its particular historical context. They suggest that a social and institutional environment that is conducive to peaceful co-existence of different ethno-religious groups can foster beneficial outcomes for the society at large. More specifically, positive externalities and spillovers of human capital across groups might have longlasting effects that go beyond their originators. While a large body of empirical work on ethnic diversity generally points to adverse consequences at global and national levels, our results seem to lend some qualified support for an optimistic view of historical diversity over the long-run. 


\section{References}

Abadie, A. and G. W. Imbens, "Large Sample Properties of Matching Estimators for Average Treatment Effects," Econometrica, 2006, 74 (1), 235-267.

_ , D. Drukker, J. Leber Herr, and G. W. Imbens, "Implementing Matching Estimators for Average Treatment Effects in Stata," The Stata Journal, 2004, 4 (3), 290-311.

Acemoglu, Daron, Simon Johnson, and James A Robinson, "Reversal of Fortune: Geography and Institutions in the Making of the Modern World Income Distribution," The Quarterly Journal of Economics, 2002, 117 (4), 1231-1294.

_, Tarek A. Hassan, and James A Robinson, "Social Structure And Development: A Legacy Of The Holocaust In Russia," Quarterly Journal of Economics, 2011, 126, 895-946.

Adalian, Rouben Paul, Historical dictionary of Armenia, Scarecrow Press, 2010.

Akçam, Taner, A shameful act: The Armenian genocide and the question of Turkish responsibility, Macmillan, 2006.

_, The young Turks' crime against humanity: the Armenian Genocide and ethnic cleansing in the Ottoman empire, Princeton University Press, 2012.

Aktan, Ali, "Osmanli Belgelerine Gore Kayseri'deki Gayrimüslim Tebaanın Durumu," Technical Report, KYTSB 1996.

Altonji, Joseph G., Todd E. Elder, and Christopher R. Taber, "Selection on Observed and Unobserved Variables: Assessing the Effectiveness of Catholic Schools," Journal of Political Economy, February 2005, 113 (1), 151-184.

Altuğ, Sumru, Alpay Filiztekin, and Şevket Pamuk, "Sources of long-term economic growth for Turkey, 1880-2005," European Review of Economic History, 2008, 12 (3), 393-430.

Arşivleri, Genel Müdürlüğü Devlet, "Osmanlı Belgelerinde Ermeniler (Armenians in Ottoman Documents 1915-1920)," 1995, 97, 134-145. 
Bayrak, Saban, 18-19. Yüzyılda Kayseri'nin Ticari Hinterlandı, Vol. IV. Kayseri ve Yoresi Tarih Sempozyumu Bildirileri, E. U. Kayseri ve Yoresi Tarih Arastırmaları Merkezi Yayını, Kayseri, 2003.

Becker, Sascha O and Andrea Ichino, "Estimation of Average Treatment Effects Based on Propensity Scores," The Stata Journal, 2002, 2 (4), 358-377.

_ and Ludger Woessmann, "Was Weber wrong? A Human Capital Theory of Protestant Economic History," Quarterly Journal of Economics, 2009, 124 (2), 531-596.

Benjamin, Braude and Lewis Bernard, Christians and Jews in the Ottoman Empire, Vol. 1: The Central Lands, New York-London, Holmes \& Meier, 1982.

Botticini, Maristella and Zvi Eckstein, "Jewish Occupational Selection: Education, Restrictions, or Minorities?," The Journal of Economic History, 12 2005, 65, 922-948.

_ and _, "From Farmers To Merchants, Conversions And Diaspora: Human Capital And Jewish History," Journal of the European Economic Association, 2007, 5 (5), 885-926.

_ and _, The Chosen Few, Princeton University Press, 2012b.

Braudel, Fernand, Civilization and Capitalism, 15th-18th Century: The wheels of commerce, Vol. 2, University of California Press, 1982.

Brenner, Robert, "Agrarian Class Structure and Economic Development in Pre-Industrial Europe," Past and Present, 1976, 70, 30-75.

Browning, Robert, History, language and literacy in the Byzantine world, Vol. 299, Variorum, 1989.

Burckhardt, Jacob, The Greeks and Greek Civilization, St. Martin's Press, 1998.

Chaney, Eric and Richard Hornbeck, "Economic Dynamics in the Malthusian Era: Evidence from the 1609 Spanish Expulsion of the Moriscos," The Economic Journal, 2015.

Davis, Donald R and David W Weinstein, "Bones, Bombs, And Break Points: The Geography Of Economic Activity," American Economic Review, 2002, 92, 1269-1289. 
Doll, Christopher NH, Jan-Peter Muller, and Jeremy G Morley, "Mapping regional economic activity from night-time light satellite imagery," Ecological Economics, 2006, 57 (1), $75-92$.

Donaldson, Dave and Richard Hornbeck, "Railroads and American Economic Growth: A "Market Access" Approach," The Quarterly Journal of Economics, 2016, pp. 799-858.

Dündar, Fuat, Modern Türkiye'nin şifresi, Vol. 225, İletişim, 2008.

Durmaz, Oya Gözel, "The Distribution of the Armenian Abandoned Properties in an Ottoman Locality: Kayseri (1915-18)," Middle Eastern Studies, 2015, 51 (5), 838-853.

Eldem, Edhem, "Capitulations and Western Trade," in Suraiya Faroqhi, ed., The Cambridge History of Turkey, vol. 3, The Later Ottoman Empire, 1603-1839, Cambridge: Cambridge University Press, 2006, pp. 283-335.

Elvidge, Christopher D, Kimberly E Baugh, Eric A Kihn, Herbert W Kroehl, and Ethan R Davis, "Mapping city lights with nighttime data from the DMSP Operational Linescan System," Photogrammetric Engineering and Remote Sensing, 1997, 63 (6), 727-734.

Erkiletlioglu, Halit, Geniş Kayseri Tarihi, Kisisel Yayinlar, 2006.

Friedman, Saul S, A History of the Middle East, McFarland, 2006.

Gennaioli, Nicola, Rafael La Porta, Florencio Lopez de Silanes, and Andrei Shleifer, "Human Capital and Regional Development," The Quarterly Journal of Economics, 2013, 105, 164.

Gerber, Haim, Economy and Society in an Ottoman City: Bursa, 1600-1700, Vol. 3, Hebrew University, 1988.

Glaeser, Edward L, JoséA Scheinkman, and Andrei Shleifer, "Economic growth in a crosssection of cities," Journal of monetary economics, 1995, 36 (1), 117-143.

_, Rafael La Porta, Florencio Lopez de Silanes, and Andrei Shleifer, "Do Institutions Cause Growth?," Journal of Economic Growth, 2004, 9 (3), 271-303. 
Grada, Cormac O, Black '47 and Beyond: The Great Irish Famine in History, Economy, and Memory, Princeton University Press, 2000.

Grosfeld, Irena, Alexander Rodnyansky, and Ekaterina Zhuravskaya, "Persistent Antimarket Culture: A Legacy of the Pale of Settlement after the Holocaust," American Economic Journal: Economic Policy, 2013, 5 (3), 189-226.

Grosjean, Pauline, "The institutional legacy of the Ottoman Empire: Islamic rule and financial development in South Eastern Europe," Journal of Comparative Economics, 2011, 39, 1-16.

Haldon, John F, Byzantium in the Seventh Century: the Transformation of a Culture, Cambridge University Press, 1990.

Haywood, John, "with Brian Catchpole, Simon Hall and Edward Barratt," Cassell's Atlas of World History, 2001.

Heldring, Leander, James A. Robinson, and Sebastian Vollmer, "Monks, Gents and Industrialists: The Long-Run Impact of the Dissolution of the English Monasteries," Working Paper 21450, National Bureau of Economic Research August 2015.

Henderson, J. Vernon, Adam Storeygard, and David N. Weil, "Measuring Economic Growth from Outer Space," American Economic Review, 2012, 102 (2), 994-1028.

Hirschon, Renée, Crossing the Aegean: an appraisal of the 1923 compulsory population exchange between Greece and Turkey, Berghahn Books, 2003.

Hornung, Erik, "Immigration and the Diffusion of Technology: The Huguenot Diaspora in Prussia," American Economic Review, 2014, 104 (1), 84-122.

Houshamadyan Project: Palu-Interethnic relations

Houshamadyan Project: Palu-Interethnic relations, http://www.houshamadyan.org/ en/mapottomanempire/vilayetdiyarbekir/palu/socio-economic-structure/interethnic-relations. html. Accessed: 2016-06-13.

İçduygu, Ahmet, "International Migration and Human Development in Turkey," Human Development Research Paper (HDRP) Series, 2009, 52 (2009). 
Inalcik, Halil, "Bursa I-XV. Asir Sanayi ve Ticaret Tarihine Dair Vesikalar," TTK Belleten, 1960, 24 (93), 45-102.

Issawi, Charles and Charles P Assawi, The economic history of Turkey, 1800-1914, University of Chicago Press Chicago, 1980.

Jedwab, Remi, Edward Kerby, and Alexander Moradi, "History, path dependence and development: Evidence from colonial railroads, settlers and cities in Kenya," The Economic Journal, 2015.

_, Noel Johnson, and Mark Koyama, "Bones, Bacteria and Break Points: The Heterogeneous Spatial Effects of the Black Death and Long-Run Growth," Technical Report, Mimeo 2016.

Johnson, Noel D and Mark Koyama, "Jewish Communities and City Growth in Preindustrial Europe," Available at SSRN, 2016.

Karpat, Kemal H., Ottoman population, 1830-1914: demographic and social characteristics, Madison: University of Wisconsin Press, 1985.

Kekecoglu, Sonay, "Seriyye Sicillerine Gore Kayseri'de Gayrimüslimler (1800-1850)," Working Paper, Cumhuriyet Universitesi Sosyal Bilimler Enstitusu $200 \%$.

Keshishian, Varty, "Houshamadyan Project: Sandjak of Marash-Commerce," http: //www.houshamadyan.org/en/mapottomanempire/vilayetaleppo/sandjakofmarash/economy/ industry-and-commerce.html 2011. Accessed: 2016-06-13.

Kévorkian, Raymond, The Armenian genocide: a complete history, IB Tauris, 2011.

Khachikyan, Armen, History of Armenia: A Brief Review, Yerevan: Edit Print, 2010.

Kuran, Timur, "The Economic Ascent of the Middle East's Religious Minorities: The Role of Islamic Legal Pluralism," The Journal of Legal Studies, 2004, 33 (2), 475-515.

_, "Why the Middle East is economically underdeveloped: historical mechanisms of institutional stagnation," The Journal of Economic Perspectives, 2004, 18 (3), 71-90.

_, The long divergence: How Islamic law held back the Middle East, Princeton University Press, 2012. 
_ and Jared Rubin, "The Financial Power of the Powerless: Socio-Economic Status and Interest Rates under Partial Rule of Law," Economic Research Initiatives at Duke (ERID) Working Paper No. 175, 2016. Available at SSRN: http://ssrn.com/abstract=2512930 or http://dx.doi.org/10.2139/ssrn.2512930.

— and Scott Lustig, "Judicial Biases in Ottoman Istanbul: Islamic Justice and Its Compatibility with Modern Economic Life," Journal of Law and Economics, 2012, 55 (3), pp. 631-666.

Lapidus, Ira M, Muslim cities in the later Middle Ages, Cambridge, Mass.: Harvard University Press., $196 \%$.

Law, Robin, The Slave Coast Of West Africa, 1550-1750: The Impact Of The Atlantic Slave Trade On An African Society, Oxford University Press, 1991.

Lovejoy, Paul E, Transformations in Slavery: A History of Slavery in Africa, Cambridge University Press, 2000.

Matossian, Bedross Der, "The Armenian Commercial Houses and Merchant Networks in the 19th Century Ottoman Empire," Turcica, 2007, 39, 147-174.

-, "The Taboo within the Taboo: The Fate of Armenian Capital at the End of the Ottoman Empire," European Journal of Turkish Studies, 2011.

Michalopoulos, Stelios and Elias Papaioannou, "Pre-Colonial Ethnic Institutions and Contemporary African Development," Econometrica, 2013, 81 (1), 113-152.

Miguel, Edward and Gérard Roland, "The long-run impact of bombing Vietnam," Journal of Development Economics, 2011, 96 (1), 1-15.

Moretti, Enrico, "Workers' education, spillovers, and productivity: evidence from plant-level production functions," The American Economic Review, 2004, 94 (3), 656-690.

Mutlu, Servet, Doğu Sorununun Kökenleri: Ekonomik Açıdan, Ötüken Yayınları, 2002.

_. "Late Ottoman population and its ethnic distribution," Turkish Journal of Population Studies, 2003, 25, 3-38. 
North, Douglass C. and Thomas Robert Paul, The Rise of the Western world: A New Economic History, Cambridge University Press, 1973.

Nunn, Nathan, "The Long-Term Effects of Africa's Slave Trades," The Quarterly Journal of Economics, 2008, 123 (1), 139-176.

Oikonomidês, Nikólaos and John Springer Langdon, Literacy in Thirteenth-Century Byzantium: An Example from Western Asia Minor, Artistide D. Caratzas, 1993.

O'Rourke, Kevin, "The Economic Impact of the Famine in the Short and Long Run," American Economic Review, 1994, 84 (2), 309-313.

Pamuk, Sevket, The Ottoman Empire and the European Capitalism, 1820-1913: Trade, Investment and Production, Cambridge University Press, $198 \%$.

Pascali, Luigi, "Banks and development: Jewish communities in the Italian Renaissance and current economic performance," Review of Economics and Statistics, 2016, 98 (1), 140-158.

Pinkovskiy, Maxim L, "Economic discontinuities at borders: Evidence from satellite data on lights at night," Technical Report 2013.

Postan, Michael M, Essays on Medieval Agriculture and General Problems of the Medieval Economy, Cambridge University Press, 1973.

Rosenbaum, P. R. and D. P. Rubin, "The Central Role of the Propensity Score in Observational Studies for Causal Effects," Biometrika, 1983, 70 (1), 41-55.

Saleh, Mohamed et al., "On the Road to Heaven: Self-Selection, Religion, and Socio-Economic Status," Technical Report, Toulouse School of Economics (TSE) 2015.

Sezen, Tahir, Osmanlı yer adları:(alfabetik sırayla), Vol. 21, TC Başbakanlık Devlet Arşivleri Genel Müdürlüğ̈̈, 2006.

Smith, Jeffrey A. and Petra E. Todd, "Does matching overcome LaLonde's critique of nonexperimental estimators?," Journal of Econometrics, 2005, 125 (1-2), 305-353.

Sombart, Werner, "The Jews and Modern Capitalism," translated by M. Epstein (New Brunswick, NJ: Transaction, 1982), 1951, 41. 
Sonyel, Salahi R, Minorities and the Destruction of the Ottoman Empire, Ankara: Turkish Historical Society, 1993.

Spitzer, Yannay, "Pale in Comparison The Economic Ecology of the Jews as a Rural Service Minority," memo, 2015.

_, "Pogroms, Networks, and Migration: The Jewish Migration from the Russian Empire to the United States, 1881-1914," Technical Report, Mimeo., Hebrew University of Jerusalem 2015.

- and Ariell Zimran, "Migrant Self-Selection: Anthropometric Evidence from the Mass Migration of Italians to the United States, 1907-1925," Manuscript, Dept. Econ., Northwestern Univ, 2014 .

Toprak, Zafer, Turkiye'de Milli Iktisat: 1908-1918, Dogan Kitap, 2012.

Turgay, Uner A, "Trade and Merchants in Nineteenth-Century Trabzon: Elements of Ethnic Conflict," in Benjamin Braude and Bernard Lewis, eds., The Central Lands. Vol. 1 of Christians and Jews in the Ottoman Empire, New York: Holmes 63 Meier, 1982, pp. 287-318.

Üngör, Uğur and Mehmet Polatel, Confiscation and destruction: the Young Turk seizure of Armenian property, A\&C Black, 2011.

Vryonis, Speros, The decline of medieval Hellenism in Asia Minor: and the process of Islamization from the eleventh through the fifteenth century, Vol. 4, University of California Press, 1971.

Waldinger, Fabian, "Peer Effects in Science: Evidence from the Dismissal of Scientists in Germany," Review of Economic Studies, 2012, 79, 838-861.

Weber, Max, "Economy and society: An outline of interpretive society," New York: Bedminster, 1968.

_, Talcott Parsons, and Richard Henry Tawney, The Protestant Ethic and the Spirit of Capitalism. Translated by Talcott Parsons... With a Foreword by RH Tawney, G. Allen 8 Unwin, 1930.

Whelan, Karl, "Economic Geography and the Long-run Effects of the Great Irish Famine," The Economic and Social Review, 1999, 30 (1), 1-20. 
Zürcher, Erik-Jan, "Greek and Turkish refugees and deportees 1912-1924," Turkology Update Leiden Project Working Papers Archive, Department of Turkish Studies, Universiteit Leiden, 2003.

Zurcher, Erik Jan, Turkey: a modern history, IB Tauris, 2004. 


\section{Appendices}

\section{A Minority Share and Post-Expulsion Asset Concentration}

In this appendix section, we lay out a simple framework of asset redistribution from an expelled minority group (Greeks or Armenians) to other groups (local Muslim population and the Muslim immigrants who settle after the expulsions). Our aim is to demonstrate that, holding other things constant, the degree of post-expulsion asset concentration (measured as a Gini index for asset holdings) increases with initial minority share in the population and per capita minority asset holdings.

There are two periods $(t=1,2) . t=1$ and $t=2$ denote the period before and after the expulsion of the minority group, respectively. In period 1 , there are two groups $j=m, n$ in a given region. $m$ stands for local Muslims and $n$ stands for the non-Muslim minority group. Total population size in period 1 is given by $N_{1}$. We denote the share of minority group in period 1 by $\lambda_{1}$. For convenience, we assume that within each group, period 1 asset holdings are the same. The values of period 1 assets per member in groups $m$ and $n$ are given by $y^{m}$ and $y^{n}$, respectively.

In period 2, all members of the minority group are expelled, and Muslim immigrants of size $n_{2}^{i}$ settle in the region. ${ }^{107}$ We let $\alpha$ denote the exogenously given replacement rate so that $n_{2}^{i}=\alpha \lambda_{1} N_{1}$. Thus, total population in period 2 is given by $N_{2}=\left[1-\lambda_{1}+\alpha \lambda_{1}\right] N_{1}$. To keep things simple, we also assume that all of minority assets are confiscated.

The assets that group $n$ leaves behind is equal to $A=\lambda_{1} N_{1} y^{n}$. These are divided among the local Muslims and the new immigrants. Part of the confiscated property is allocated to the Muslim immigrants that arrived after the expulsion. We denote the amount of transfer per immigrant by $y^{i}$

The remaining assets are captured by (or auctioned to) local Muslims. Only $s$ fraction of the local Muslims (e.g. local Muslim elite) are able to get a share from A. Hence, the remainder of minority property after the transfers to immigrants is equally divided among an influential local elite of size $s\left(1-\lambda_{1}\right) N_{1}$. As a result, in period 2, there are three Muslim groups distinguished

\footnotetext{
${ }^{107}$ Note that model predictions do not change in the absence of migrant replacement.
} 
by their asset holdings: Rich local Muslims $(r l)$, poor local Muslims $(p l)$ and immigrants $(i)$. The share of group $r l$ in period 2 population is given by

$$
\lambda_{2}^{r l}=\frac{s\left(1-\lambda_{1}\right)}{1-\lambda_{1}+\alpha \lambda_{1}}
$$

Asset per person in this group is equal to whatever they had in the first period plus the amount they obtain from the division of remaining minority property:

$$
y_{2}^{r l}=y^{m}+\frac{\lambda_{1} N_{1} y^{n}-\alpha \lambda_{1} N_{1} y^{i}}{s\left(1-\lambda_{1}\right) N_{1}}=\frac{s\left(1-\lambda_{1}\right) y^{m}+\lambda_{1}\left(y^{n}-\alpha y^{i}\right)}{s\left(1-\lambda_{1}\right)}
$$

The share of poor local Muslims in period 2 population is given by

$$
\lambda_{2}^{p l}=\frac{\left(1-\lambda_{1}\right)(1-s)}{1-\lambda_{1}+\alpha \lambda_{1}} .
$$

Since they do not receive any transfer, their period 2 asset holding is simply equal to $y_{2}^{p l}=y^{m}$.

We denote the amount of assets owned by each immigrant in period 2 by $y_{2}^{i}$. Assuming -for simplicity- that immigrants arrive without any property $y_{2}^{i}$ is equal to the amount of minority assets transfered to each immigrant, i.e. $y_{2}^{i}=y^{i}$. Population share of immigrants in period 2 is given by

$$
\lambda_{2}^{i}=\frac{\alpha \lambda_{1}}{1-\lambda_{1}+\alpha \lambda_{1}}
$$

We assume that each group is populated by a continuum of agents. We also assume that the transfer to immigrants is strictly below the assets owned by poor local Muslims, i.e., $y^{i}<y_{2}^{p l}=y^{m}$. Hence, the groups are ranked by their per capita asset holdings as $y_{2}^{i}<y_{2}^{p l}<y_{2}^{r l}$. Since agents in 
each group are homogenous with respect to their asset holdings, ranking of individuals within each group is irrelevant. Denote the average asset holding per capita in the region in period 1 by

$$
\bar{y}_{1}\left(\lambda_{1}\right) \equiv \lambda_{1} y^{n}+\left(1-\lambda_{1}\right) y^{m} .
$$

Consistent with our historical setting, we assume that minorities were on average wealthier than Muslims, i.e., $y^{n}>y^{m}$. Hence, average asset holdings per capita in the region is an increasing function of the share of the minorities $\lambda_{1}$ in period 1 .

Then, with a bit of algebra one can show that in period 2 , the share of the poorest $\lambda$ fraction of the population owns $L(\lambda)$ fraction of total assets where

$$
L(\lambda)= \begin{cases}L^{i}(\lambda):=\psi\left(\lambda_{1}\right) \frac{y_{2}^{i}}{\bar{y}_{1}\left(\lambda_{1}\right)} \lambda & \text { if } \lambda \in\left[0, \lambda_{2}^{i}\right] \\ L^{p l}(\lambda):=L^{i}\left(\lambda_{2}^{i}\right)+\psi\left(\lambda_{1}\right) \frac{y^{m}}{\bar{y}_{1}\left(\lambda_{1}\right)}\left(\lambda-\lambda_{2}^{i}\right) & \text { if } \lambda \in\left(\lambda_{2}^{i}, \lambda_{2}^{i}+\lambda_{2}^{p l}\right] \\ L^{r l}(\lambda):=L^{p l}\left(\lambda_{2}^{i}+\lambda_{2}^{p l}\right)+\psi\left(\lambda_{1}\right) \frac{y_{2}^{r l}}{\bar{y}_{1}\left(\lambda_{1}\right)}\left(\lambda-\lambda_{2}^{i}-\lambda_{2}^{p l}\right) & \text { if } \lambda \in\left(\lambda_{2}^{i}+\lambda_{2}^{p l}, 1\right]\end{cases}
$$

where

$$
\psi\left(\lambda_{1}\right):=1-\lambda_{1}+\alpha \lambda_{1}
$$

in other words, $L(\lambda)$ is the Lorenz curve for asset holdings. Using the Lorenz curve, we can derive the resulting Gini index as

$$
G=\left(\lambda_{2}^{i}+\lambda_{2}^{p l}\right)\left(1-L^{i}\left(\lambda_{2}^{i}\right)\right)-\left(1-\lambda_{2}^{i}\right) L^{p l}\left(\lambda_{2}^{i}+\lambda_{2}^{p l}\right)
$$

Proposition 1. Asset concentration $G$ (measured as inequality) in period 2 increases with the level of period 1 assets per non-Muslim minority member $y^{n}$ and the share of minorities $\lambda_{1}$ in period 1 population. 
Proof. Combining the expressions in equations (3)-(10), we can rewrite the gini index for asset holdings as

$$
G=G\left(\lambda_{1}\right):=A\left(\lambda_{1}\right)+B\left(\lambda_{1}\right)\left[1-C\left(\lambda_{1}\right) y^{m}\right]-D\left(\lambda_{1}\right) y^{i}
$$

where

$$
\begin{gathered}
A\left(\lambda_{1}\right):=\frac{\alpha \lambda_{1}}{\psi\left(\lambda_{1}\right)}, \\
B\left(\lambda_{1}\right):=\frac{(1-s)\left(1-\lambda_{1}\right)}{\psi\left(\lambda_{1}\right)}, \\
C\left(\lambda_{1}\right):=\frac{1-\lambda_{1}}{\overline{y_{1}}\left(\lambda_{1}\right)} \text { and } \\
D\left(\lambda_{1}\right):=\frac{\alpha \lambda_{1}\left[\left(1-\lambda_{1}\right)(2-s)+\alpha \lambda_{1}\right]}{\psi\left(\lambda_{1}\right) \overline{y_{1}}\left(\lambda_{1}\right)} .
\end{gathered}
$$

First note that the above expression depends on $y^{n}$ only through its impact on the average assets per capita in the region $\overline{y_{1}}\left(\lambda_{1}\right)$ which is given by equation $(7)$. In particular, we have

$$
\begin{gathered}
\frac{\partial \bar{y}_{1}\left(\lambda_{1}\right)}{\partial y^{n}}=\lambda_{1}>0 \\
\frac{\partial A\left(\lambda_{1}\right)}{\partial \bar{y}_{1}\left(\lambda_{1}\right)}=0, \quad \frac{\partial B\left(\lambda_{1}\right)}{\partial \bar{y}_{1}\left(\lambda_{1}\right)}=0, \quad \frac{\partial C\left(\lambda_{1}\right)}{\partial \bar{y}_{1}\left(\lambda_{1}\right)}<0, \quad \frac{\partial D\left(\lambda_{1}\right)}{\partial \bar{y}_{1}\left(\lambda_{1}\right)}<0 \\
\frac{\partial G\left(\lambda_{1}\right)}{\partial C\left(\lambda_{1}\right)}<0 \quad \text { and } \quad \frac{\partial G\left(\lambda_{1}\right)}{\partial D\left(\lambda_{1}\right)}<0
\end{gathered}
$$

Thus, we can conclude that $G$ is increasing in $y^{n}$. To prove the second claim, note that

$$
\frac{\partial \overline{y_{1}}\left(\lambda_{1}\right)}{\partial \lambda_{1}}=y^{n}-y^{m}>0
$$

where the inequality follows from our assumption that non-Muslim minorities were richer than Muslims. Next, one can show with some algebra that

$$
\frac{\partial D\left(\lambda_{1}\right)}{\partial \lambda_{1}}<0
$$

So it remains to show that the sum of the first two terms in equation (11) is increasing in $\lambda_{1}$,i.e.

$$
\frac{\partial A\left(\lambda_{1}\right)}{\partial \lambda_{1}}+\frac{\partial B\left(\lambda_{1}\right)}{\partial \lambda_{1}}\left[1-C\left(\lambda_{1}\right) y^{m}\right]-B\left(\lambda_{1}\right) y^{m} \frac{\partial C\left(\lambda_{1}\right)}{\partial \lambda_{1}}>0
$$


The first term in equation (21) is positive and the third term is negative. However, the second term is negative. So the sign of the above expression depends on whether the first and third terms combined dominate the second term which is negative. With some algebra we can show that the sign of the above expression is equal to the sign of the following expression

$$
\begin{gathered}
\alpha\left[\left(1-\lambda_{1}\right) y^{m}+\lambda_{1} y^{n}\right]^{2}+(1-s)\left[\left(1-\lambda_{1}\right)^{2} y^{n} y^{m}-\alpha \lambda_{1}^{2}\left(y^{n}\right)^{2}\right]= \\
\alpha\left[\left(1-\lambda_{1}\right)^{2}\left(y^{m}\right)^{2}+2 \lambda_{1}\left(1-\lambda_{1}\right) y^{n} y^{m}\right]+(1-s)\left(1-\lambda_{1}\right)^{2} y^{n} y^{m}+\alpha s \lambda_{1}^{2}\left(y^{n}\right)^{2}>0
\end{gathered}
$$

This completes the proof.

\section{B Data Appendix}

\section{B.1 Variable Definitions and Sources}

Population Density: Natural logarithm of district population per square kilometer. It is computed using the Turkish Population Censuses and the surface area of each district as reported by the National Mapping Agency of Turkey under the Ministry of National Defense. Census results can be accessed through TurkStat's web application.

As for the 1893 population density, where it is necessary, we use a proxy. 1893 census figures are reported for Ottoman districts (kazas), and information about their boundaries are not available. This makes it impossible to compute population density as the areas of kaza are not known. Therefore, we use the sum of areas of all modern districts that were name-matched to a given kaza as a proxy for total area of that kaza. Using this proxy, we construct population density figures in 1893 for each kaza.

Urbanization Rate: The share of district population who lives within the municipal boundaries that define the district centers. It is computed using data from the Turkish Population Census on the distribution of the population within and outside the district centers.

Average Luminosity: The variable measures for a given year the density of time-stable nighttime lights at the district level. The information on light density comes from the Defense Meteorological Satellite Program's (DMSP) Operational Linescan System. DMSP reports images of the earth at 
night captured from 20:30 to 22:00 local time. The satellites detect lights from human settlements, fires, gas flares, lightning, and the aurora. Light density measure is a six-bit number (ranging from 0 to 63) calculated for every 30 -second area (approximately 1 square kilometer). Overlaying all images captured during a calendar year, dropping images where lights are shrouded by cloud or overpowered by the aurora or solar glare (near the poles), and removing ephemeral lights like fires and lightning, an annual composite image of time-stable lights are created. We compute district level luminosity by averaging across all light density pixels that fall within the district boundaries.

Historical Minority Population Shares: There are two potential sources of data on historical population of minorities. The first one is the Ottoman General Census of 1881/82-1893. The second one is the Population Statistics of the Ottoman State in 1914, i.e. the year before the mass deportations of Armenians started. The 1914 statistics were prepared using the figures from the 1905/1906 census, and adjusting for births and deaths registered in the subsequent years. Various tribes in Eastern Anatolia could not be counted, and hence, the information on the population size of these tribes was based on estimates. More importantly for the purpose of our analysis, the major problem with the 1914 population figures is that, in several regions of the Eastern and Southeastern Anatolia, the tensions between Armenians and the state forces have intensified during the final years of the reign of Sultan Abdulhamid II. Armenian national movement also gained momentum in this period. In some regions, Armenians organized armed self-defense forces in response to attacks by Kurdish tribesmen and irregulars. Armenian revolutionary activity in the East and the ensuing violence were met with a heavily armed response by the central government. In the mid-1890s, several massacres took place against the Armenians in the eastern provinces of the Ottoman Empire. These massacres were carried out by the Hamidian Regiments -irregular corps armed by the state and named after the sultan. They led to 200,000 to 300,000 dead according to some estimates (Akçam, 2006). During this period, several regions in the East of Anatolia have been the stage of the Armenian uprisings, and the clashes between Armenian militia and Ottoman Empire's forces including the Sasun Rebellion of 1894, the Zeitun Rebellion of 1895-1896 and the 1896 Defense of Van. The incidents continued in the immediate aftermath of the Young Turk Revolution of 1908. In April 1909, anti-Armenian pogroms in Adana Vilayet resulted in the deaths of as many as 20,000- 
30,000 Armenians (Adalian, 2010). The casualties caused by sporadic clashes between state forces and the Armenian rebels, the civilians who died during the massacres committed against Armenians over the period between 1894 and 1914, and the people who migrated elsewhere to escape from violence all make the 1914 population figures less suitable for an analysis of the long-term legacy of Armenian communities in Anatolia. In addition, the Young Turk government, who took power in 1908 and initiated the Turkification of Anatolia, had incentives to under-report minority figures to deny them higher representation in the state and the military, which makes 1914 population numbers less reliable (Üngör and Polatel, 2011).

Therefore, in the construction of the historical population measures, we use data on Greek, Armenian and total population reported by the Population Census of the Ottoman Empire that was conducted during the period 1881-1893. The census measures were reported either at the kaza (Ottoman district) or independent sancak level (when there is no kaza designation). The variables measure for each modern district in 2000, the share in total population of Armenian and Greek inhabitants of the Ottoman location (kaza or sancak) that was matched with this district. In rare cases when a given modern district is matched with multiple Ottoman kazas, the minority population shares reflect the overall share of these populations in the combination of these kazas. 1881-1893 Ottoman Census was the first census where females were also counted. The census used several ethnic-confessional categories for the Christian population. The 1893 population data used in this study were published for the first time by Karpat (1985). As Karpat (1985) puts it, "These population records issued in 1893 represent the most complete and reliable Ottoman population figures compiled in the nineteenth century. Unlike earlier general population statistics, these gave precise and detailed information on the population of all areas, noting the districts and regions where the census was not completed and providing estimates for the areas not subjected to individual census and registration. The figures in these statistics were considered definitive and reliable, and were used as a basis for official statistics concerning the Ottoman population and for subsequent administrative measures." Armenian share in Ottoman district $d$ is computed as

$$
\text { Armenian Share }_{d}=\frac{\text { Armenian Population }_{d}}{\text { Total Population }_{d}}
$$


Greek population share is calculated likewise.

Estimated Minority Population Shares: In Table S.1, we include in our sample those regions with incomplete population counts, and for Ottoman districts in these regions we impute estimated population shares as follows: For each Ottoman province or sancak with incomplete census counts, first we take the estimated (but admittedly unreliable) figure for uncounted population as reported by the census authorities. Records suggest that almost all these uncounted groups are nomadic Muslim tribes. Therefore, we distribute the uncounted population to each Ottoman district in that given province or sancak based on what fraction of the Muslim province/sancak population lived in that particular district. Formally, the estimated Armenian share in such a district is computed as

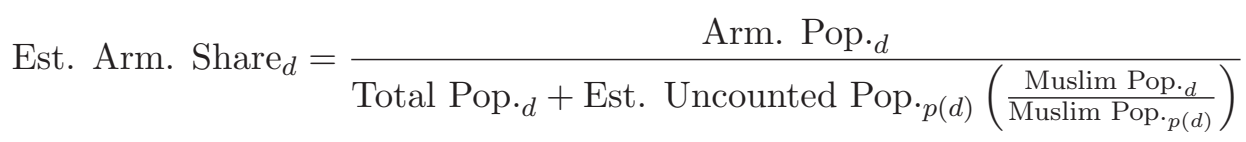

where $p(d)$ denotes the Ottoman province or sancak where district $d$ is located. Estimated Greek share is calculated likewise.

Longitude and Latitude: The latitude and longitude of the district centers in degrees. The values are retrieved via the GPS Visualizer's address locator web application and utilizing the Bing Maps database on location names and coordinates.

Average Elevation and Standard Deviation of Elevation: Average elevation and the standard deviation of elevation in a given district. Raw elevation data are downloaded from DIVA-GIS in Grid format. These data are a version of the CGIAR SRTM dataset (originally provided at 3 seconds resolution) aggregated to 30 seconds resolution. Average elevation is simply the mean of the values corresponding to those elevation grids that fall within a given district. Standard deviation of elevation is the standard deviation across the same grids. They are computed using ArcGIS®software. The original variable is given in meters. In regressions we rescale average 
elevation and standard deviation of elevation by dividing these measures by 1000 .

Lake: A dummy which takes a value of 1 if a lake overlaps (partly or partially) with the territory of the district and 0 otherwise. The shapefile is downloaded from DIVA-GIS in vector format. The primary source is the Digital Chart of the World. The spatial computations are made using ArcGIS®software.

Sea: A dummy which takes a value of 1 if a district is adjacent (touches) a sea body, i.e., Marmara Sea, Black Sea, Mediterranean Sea or Aegean Sea, and 0 otherwise. The shapefile is downloaded from DIVA-GIS in vector format. The primary source is the GADM database of Global Administrative Areas (version 1.0). The spatial computations are made using ArcGIS®software.

Major River: A dummy which takes a value of 1 if a major river goes through any part of the district territory and 0 otherwise. The shapefile for rivers is downloaded from DIVA-GIS in vector format. The primary source is the Digital Chart of the World. Major rivers are spatially selected by cross-checking with Turkey's Map of Rivers and Lakes created by Ramazan Saygili. The spatial computations are made using ArcGIS@software.

Mean Annual Temperature and Precipitation: These variables show average annual temperature and precipitation over the period 1960-1990. Data for these climatic indicators are retrieved from GAEZ data portal and they are provided at the grid cell level. We compute averages across cells that fall within modern district boundaries using ArcGIS®software. Finally, we rescale the resulting averages by dividing by 1000 .

Suitability for Cultivation of the Crop with Greatest Potential: This is a combined measure of suitability for main agricultural products in Turkey. It shows the maximum value of the indices of suitability for cultivation among the following eight crops that historically dominate agricultural production of Turkey: sugar beet, wheat, barley, olive, tobacco, potato, cotton, tea. The suitability data for these crops are borrowed from GAEZ data portal. We use crop suitability indices that are estimated for low input level rain-fed cereals. The index for each crop is provided for individual grid cells with values ranging between 0 and 10000 . We compute averages across the grid cells that 
fall within modern district boundaries using ArcGIS@software. Finally, we rescale the resulting averages by dividing by 1000 .

Distance to Railroad in 1910: The logarithm of distance of a district (in kilometers) to the nearest railroad in 1910. The image file showing the Anatolian railroads in 1910 is downloaded here and digitized using ArcGIS@software. Distance calculations are also made using ArcGISß.

Distance to Major 19th Century Port: The logarithm of distance of a district (in kilometers) to the nearest major 19th century port. The following were the major ports of the 19th century: The ports of Constantinople (Istanbul), Izmir (Smyrna), Samsun, Trabzon, Mersin, and Iskenderun (Alexandretta). The spatial computations are made using ArcGIS@software.

Log Distance to War Front (1919-1922): Logarithm of distance to the nearest war front during the Turkish War of Independence that took place during the period 1919-1922. The spatial computations are made using ArcGIS®software.

Log WWI Soldier Casualty: Logarithm of total number of soldiers in the Ottoman Army who died in battle during the First World War and whose birth province contains the district in question. The casualty data are retrieved from the List of Martyrs provided by the Turkish Ministry of National Defense.

Share of immigrants in province who arrived and were settled during 1921-1929: The number of immigrants in a given province in Turkey who settled during 1921-1929 period. We divide this number by 1927 province population. Source: Turkish Statistical Yearbook, 1930, Vol. 3.

Share of Kurdish Speakers in province in 1927: Source data give us the number of Kurdish speakers in the total population in a given province in 1927. These data come from the 1927 population Census of the Republic of Turkey.

Central kaza/sancak dummy: A dummy which takes a value of 1 if the district in question is matched either to the central kaza (the central Ottoman district) of a sancak or to the central 
sancak of a vilayet (Ottoman province) -the latter applies only for those vilayets which only have sancak subdivisions. The variable captures the location of historical economic centers and more urbanized places.

Distance to Istanbul: The logarithm of distance of a district (in kilometers) to Istanbul. The spatial computations are made using ArcGIS $®$ software. The shapefile is downloaded from DIVAGIS in vector format. The primary source is the GADM database of Global Administrative Areas (version 1.0). The spatial computations are made using ArcGIS®software.

Distance to Nearest National Border: The logarithm of distance of a district (in kilometers) to the nearest modern border of Turkey with any of its neighbors. The spatial computations are made using ArcGIS®)software. The shapefile is downloaded from DIVA-GIS in vector format. The primary source is the GADM database of Global Administrative Areas (version 1.0). The spatial computations are made using ArcGISßsoftware.

Distance to Anatolian Silk Road: The logarithm of distance of a district (in kilometers) to the nearest Anatolian Silk Road. The spatial computations are made using ArcGIS®software. The primary source is the Old World Trade Routes (OWTRAD) Project.

Distance to Ottoman Trade Routes: The logarithm of distance of a district (in kilometers) to the nearest Ottoman Trade route. The spatial computations are made using ArcGIS®software. The primary source is the Old World Trade Routes (OWTRAD) Project.

Distance to Historical Armenian Kingdom Capitals: The logarithm of distance of a district (in kilometers) to the historical Armenian Kingdom capitals. We calculate four separate distance variables for four separate Armenian Kingdom capitals. These capitals were Van (860-590 BC), Artashat (176-77 BC, 69-120 AD), Tigranakert/Silvan (77-69 BC), and Sis/Kozan (1198-1375). The spatial computations are made using ArcGISßsoftware.

Number of Ancient Greek Sites: The logarithm of one plus the number of ancient Greek sites within a radius of 20 to $50 \mathrm{~km}$ of a given district. The spatial computations are made using ArcGISßsoftware. The primary source is the Ancient-Greece project. 
Education Outcomes in 2000: We use 2000 Census figures to compute district level high school and university completion rates among the population aged 6 and above. We exclude from this base population those respondents whose education status is unknown. High school graduates consist of those who completed either a high school or a vocational school that is equivalent to a high school. Census results can be accessed through TurkStat's web application.

Number of Armenian and Greek School Buildings per Muslim in 1893: Ratio between the number of Armenian or Greek school buildings within a district as of 1912 and the number of Muslims in that district in 1893. The spatial computations are made using ArcGISßsoftware. The primary source for minority school buildings is the Hrant Dink Foundation's Revealing and Advocating the Multi-Cultural Heritage of Anatolia Project.

Land Holdings Concentration in 1997: Source data for our measure of land concentration come from 1997 Village Inventory published by State Institute of Statistics of the Turkish Republic. This inventory provides various statistics based on the information collected from all localities with a village status and aggregated to the district level. We use data on land plots owned by households that are grouped into 11 land size brackets. For each district, we have information about (i) number of individual land plots, (ii) total size of land plots, and (iii) number of land owning households that fall into each land size bracket. Since we do not have household level data on the size of land holdings, we approximate a Lorenz curve for land size distribution among households under two strong but inevitable assumptions. We assume that (a) within each land size bracket, total land is distributed equally among households in that bracket, and (b) treat households owning multiple land plots as separate households. Under these assumptions, we can order households by the size of their land holdings into 11 categories $(\mathrm{k}=1,2, \ldots, 11)$ and compute for each district (1) the cumulative share of households $\mathrm{X}(\mathrm{k})$ that fall into a land size category of $\mathrm{k}$ or below, and (2) the cumulative share $\mathrm{Y}(\mathrm{k})$ of total land (in terms of size) in the district that is owned by these households such that $\mathrm{X}(11)=1$ and $\mathrm{Y}(11)=1$. Using this Lorenz curve for discrete categories of households, we approximate an index, akin to Gini, for land distribution that is equal to $G=1-\sum_{j=1}^{11}[X(j)-X(j-1)] *[Y(j)+Y(j-1)]$ where $\mathrm{X}(0)=\mathrm{Y}(0)=0$.

Number of Armenian and Greek Buildings per 1935 population: Ratio between the 
number of Armenian or Greek buildings within a district as of 1912 and 1935 population of that district. The spatial computations are made using ArcGIS®software. The primary source for minority buildings is the Hrant Dink Foundation's Revealing and Advocating the Multi-Cultural Heritage of Anatolia Project.

\section{Share of Township Population in Kayseri Province in 2012 with High School Degree} and Above: To construct this variable, we use data on the educational breakdown of the township (belde) populations residing in Kayseri Province obtained from the 2012 Address Based Population Registry System (ADNKS) which is provided by the Turkish Statistical Institute (TUIK). The raw data are available at the neighborhood (mahalle) level for people above the age of six. Information is available only for those neighborhoods with a population above 50, and all neighborhood-education cells with fewer than 15 people are censored. Population of foreign citizens are not included in the sums. For all neighborhoods with censored education cells, we impute numbers for the censored cells as follows: If, in neighborhood $\mathrm{j}$ situated in district $\mathrm{i}$, the population figure for a given education cell (say high school graduates) is censored, we first compute the average of the shares of high school graduates across all neighborhoods in district i. Then we apply this average share of high school graduates to the total population of neighborhood j. If the resulting number of high school graduates is strictly below 15 , then we impute this number for that cell. Otherwise, we impute 14 as the population of high school graduates. This measure is only available for non-village locations in Kayseri. Hence, it is available only for 48 locations. 


\section{Online Appendix}

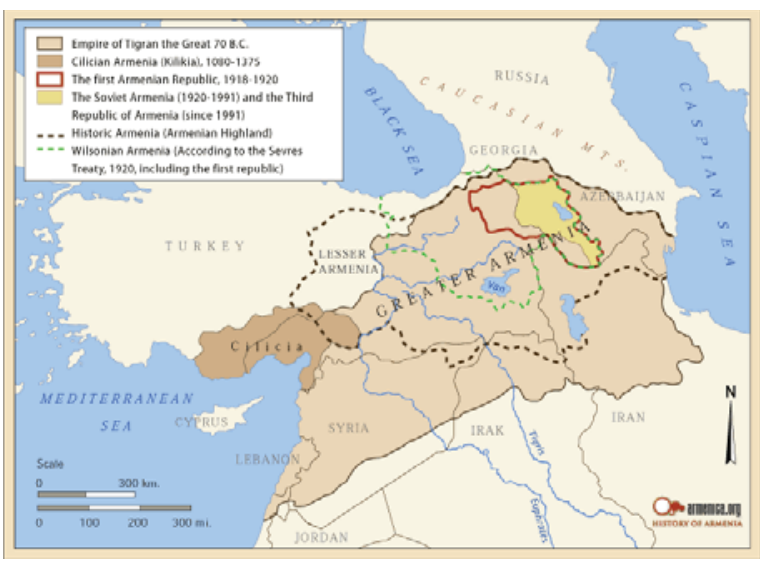

(A) Armenian Homeland throughout History

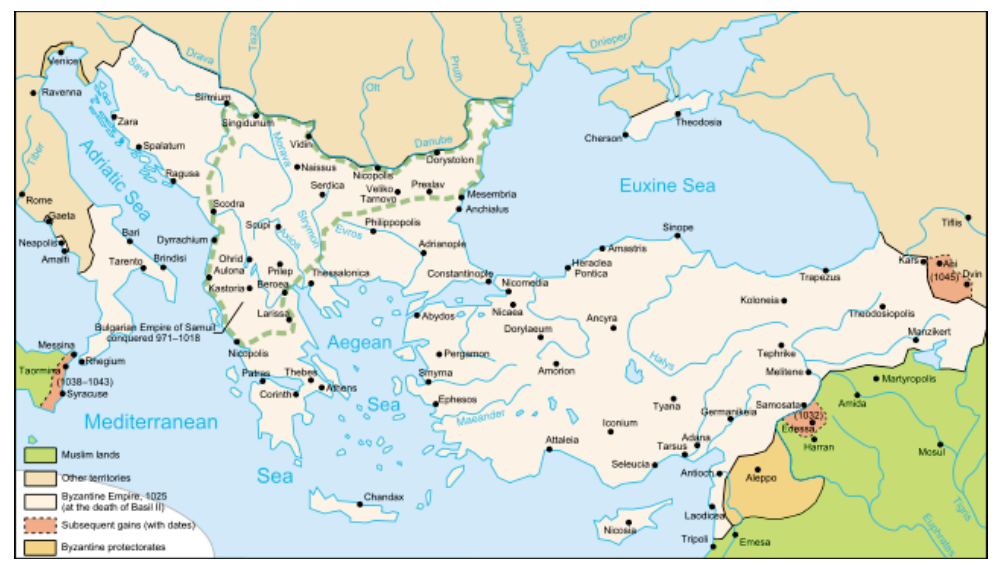

(B) The Byzantine Empire by 1025

Figure S.1: Armenian and Greek Homelands 


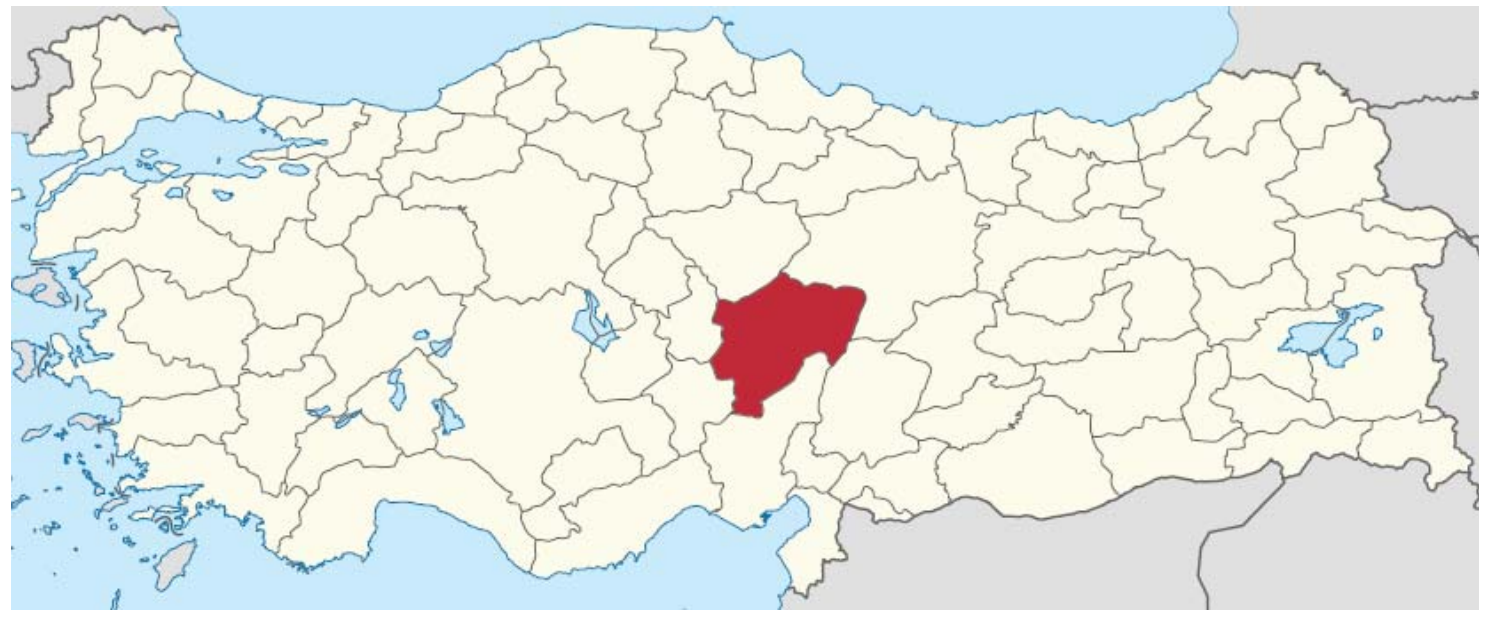

Figure S.2: Province of Kayseri 
Dependent Variable: Average luminosity (1992-2013) within 3km of Village/Town
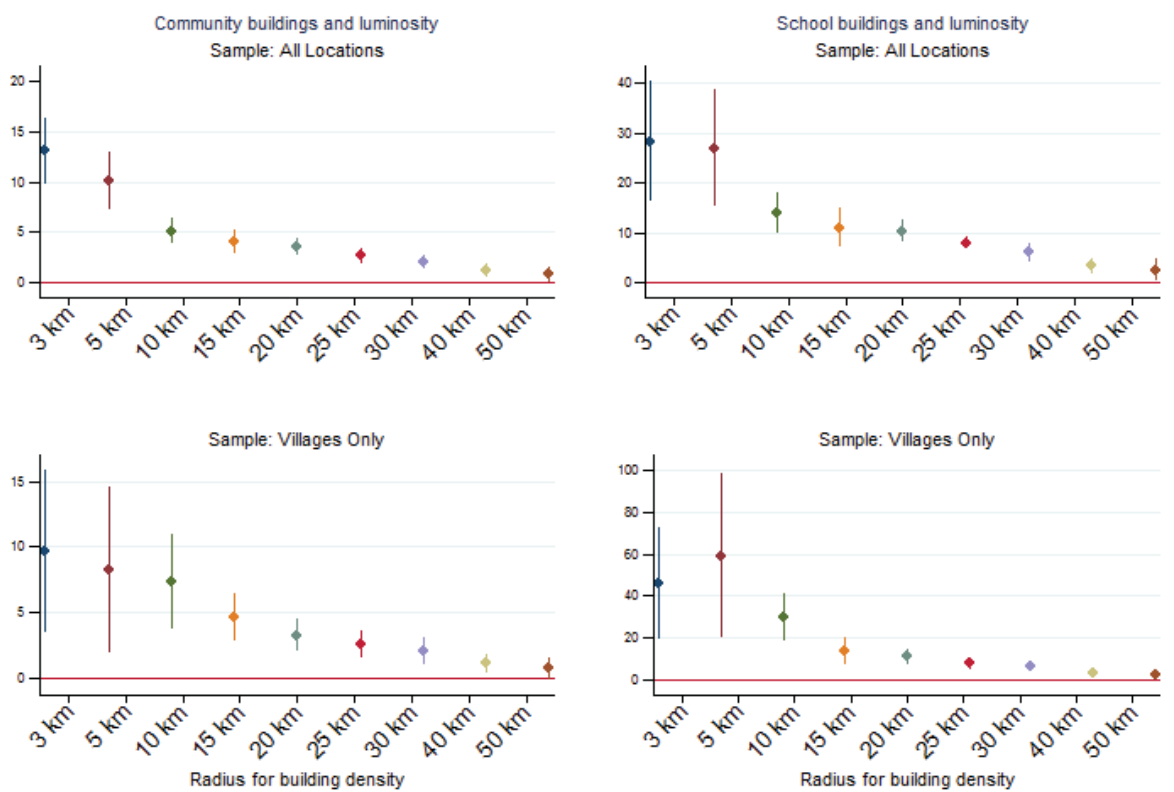

Dependent Variable: Average luminosity (1992-2013) within 10km of Village/Town
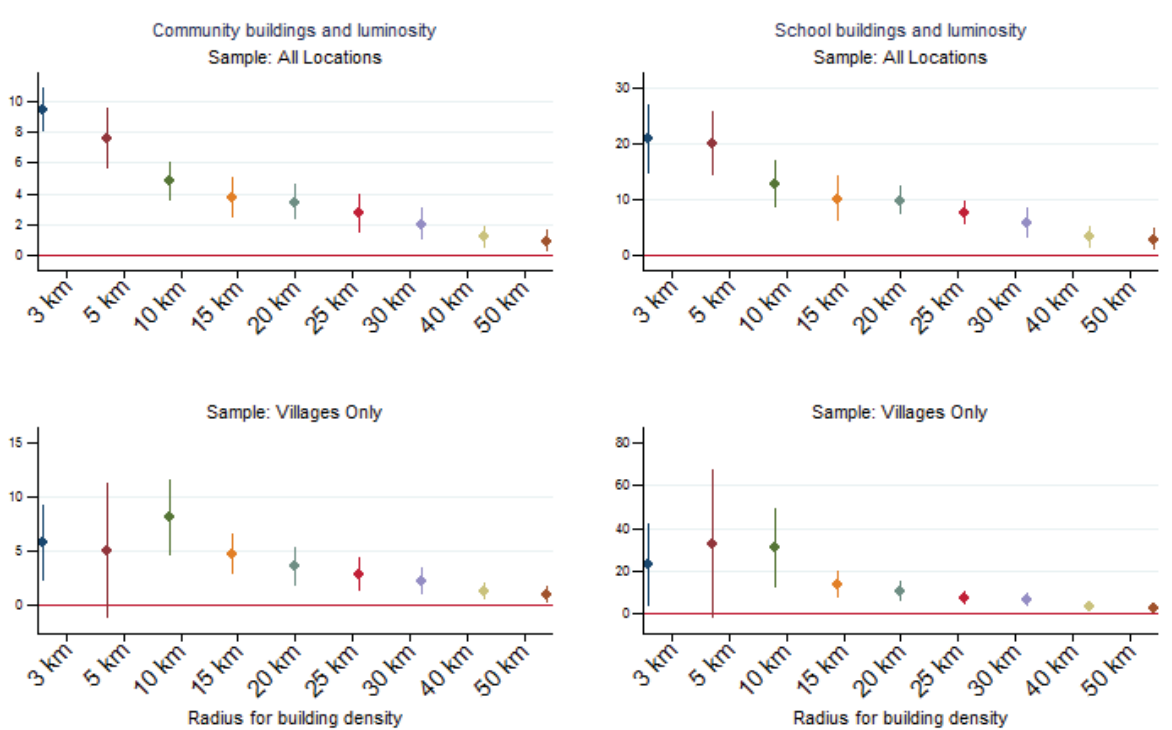

Note: All locations sample contains 443 observations. Village sample contains 395 observations. Plotted coefficients show the percentage change in average luminosity in response to one more building within a given distance to town/village centroid. Regressions include subdistrict (bucak)
fixed effects. Standard errors are clustered at subdistrict level. $95 \%$ confidence intervals are drawn for each point estimate.

FiguRE S.3: Historical Armenian Buildings and Economic Activity in Kayseri Province 
Dependent Variable: Average luminosity (1992-2013) within 3km of Village/Town
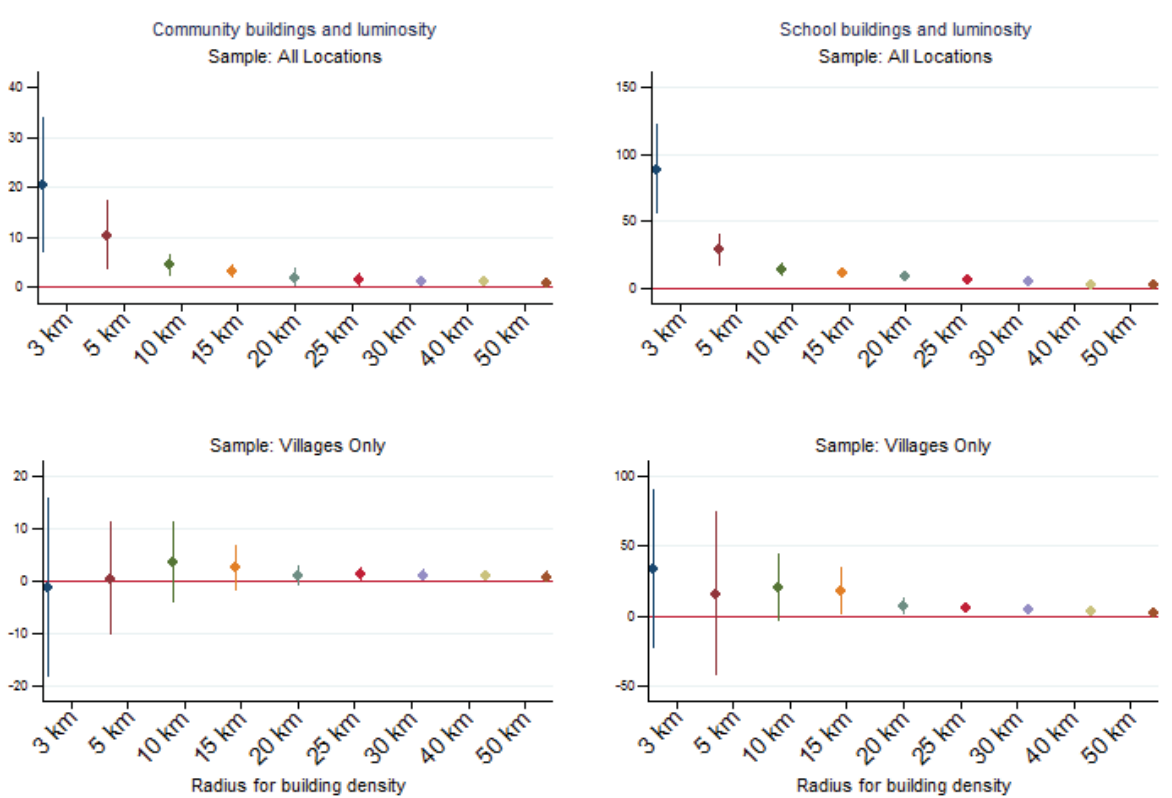

Dependent Variable: Average luminosity (1992-2013) within 10km of Village/Town
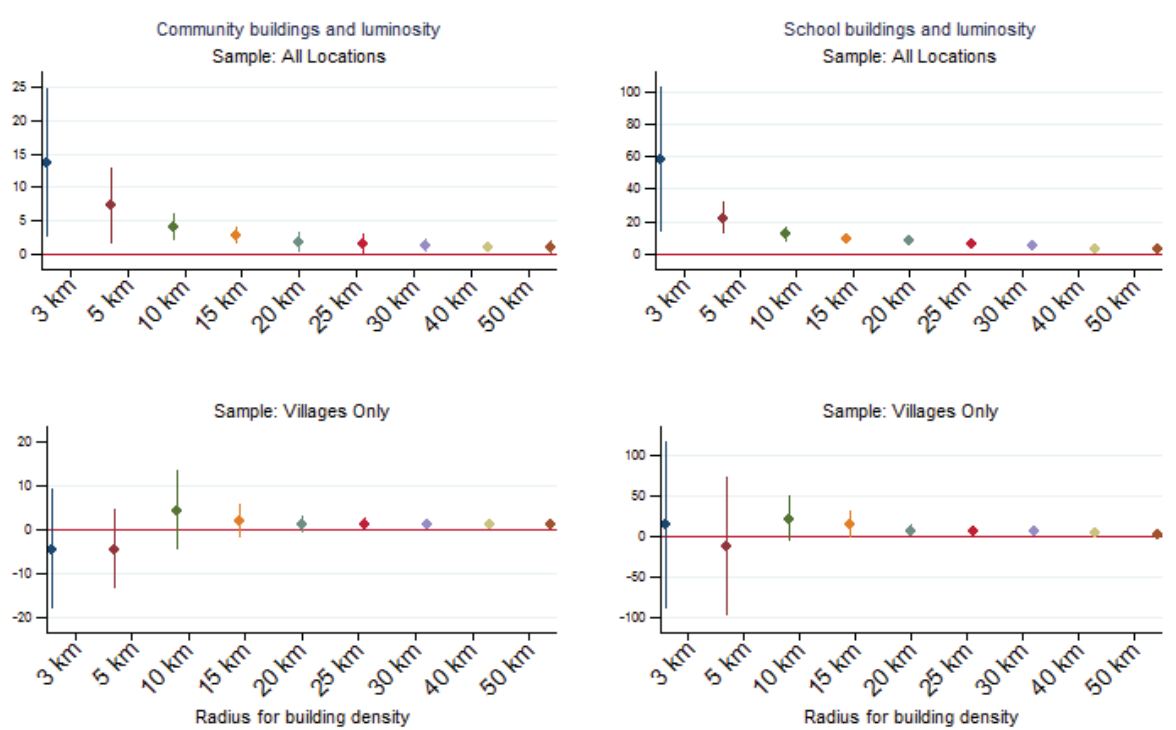

Note: All locations sample contains 443 observations. Village sample contains 395 observations. Plotted coefficients show the percentage change in average luminosity in response to one more building within a given distance to town/village centroid. Regressions include subdistrict (bucak)
fixed effects. Standard errors are clustered at subdistrict level. $95 \%$ confidence intervals are drawn for each point estimate.

FiguRE S.4: Historical Greek Buildings and Economic Activity in Kayseri Province 
TABLE S.1: Robustness of Main Results to Using Estimated Minority Shares for Incomplete Census Districts

\begin{tabular}{|c|c|c|c|c|c|}
\hline & $(1)$ & $(2)$ & $(3)$ & (4) & $(5)$ \\
\hline & Population Density & Urbanization & \multicolumn{3}{|c|}{ Luminosity } \\
\hline & OLS & OLS & OLS & IV GMM & IV GMM \\
\hline Estimated Armenian share, 1881-1893 & $\begin{array}{c}1.040^{* * *} \\
{[0.353]}\end{array}$ & $\begin{array}{c}0.438^{* * *} \\
{[0.097]}\end{array}$ & $\begin{array}{c}0.945^{* *} \\
{[0.394]}\end{array}$ & $\begin{array}{l}1.961^{*} \\
{[1.064]}\end{array}$ & \\
\hline Estimated Greek share, 1881-1893 & $\begin{array}{c}0.900^{* * *} \\
{[0.299]}\end{array}$ & $\begin{array}{c}0.186^{* * *} \\
{[0.060]}\end{array}$ & $\begin{array}{c}1.256^{* * *} \\
{[0.274]}\end{array}$ & & $\begin{array}{c}6.544^{* * *} \\
{[2.124]}\end{array}$ \\
\hline Log(Population density, 1927) & $0.681 * * *$ & $0.070 * * *$ & $0.561^{* * *}$ & $0.559 * * *$ & $0.536^{* * *}$ \\
\hline Observations & 859 & 859 & 859 & 859 & 859 \\
\hline Baseline controls & Yes & Yes & Yes & Yes & Yes \\
\hline Modern subregion dummies & Yes & Yes & Yes & Yes & Yes \\
\hline Adjusted R-squared & 0.471 & 0.115 & 0.488 & & \\
\hline Kleibergen-Paap F-statistic & & & & 20.844 & 20.076 \\
\hline Partial R2 on excluded instruments & & & & 0.144 & 0.035 \\
\hline Hansen J statistic p-value & & & & 0.257 & \\
\hline
\end{tabular}

Notes: This table presents results from the regressions of Log Population Density in 2000, Urbanization Rate in 2000, and Log Average Luminosity in 2000 on estimated historical minority shares for incomplete census regions, controlling for past population density, geographical variables, and subregion fixed effects. In column (4), the excluded instruments are the Log distances to Van, Sis and Silvan. In column (5), the excluded instrument is the number of Ancient Greek sites within $50 \mathrm{~km}$. Robust standard errors, clustered at the modern Turkish province (il) level, are reported in parentheses. *** denotes statistical significance at the 1 percent level, ** at the 5 percent level, and $*$ at the 10 percent level. 
TABle S.2: Mean Difference Tests for Treated and Control Districts

\begin{tabular}{|c|c|c|c|c|}
\hline Panel A: Armenian Treatment & Mean Treated & Mean Control & Mean Difference & P-Value \\
\hline Longitude & 33.46 & 33.32 & -0.14 & 0.66 \\
\hline Latitude & 39.39 & 39.24 & -0.15 & 0.17 \\
\hline Average Elevation & 912.62 & 891.55 & -21.07 & 0.56 \\
\hline Std. Elevation & 241.69 & 270.04 & $28.35^{* *}$ & 0.01 \\
\hline Lake & 0.30 & 0.28 & -0.02 & 0.57 \\
\hline Sea & 0.20 & 0.23 & 0.02 & 0.48 \\
\hline Major Rivers & 0.26 & 0.30 & 0.04 & 0.23 \\
\hline Temperature & 0.01 & 0.01 & 0.00 & 0.11 \\
\hline Precipitation & 0.63 & 0.66 & $0.03^{*}$ & 0.07 \\
\hline Suitability to Cultivation & 4.26 & 4.12 & -0.14 & 0.24 \\
\hline$N$ & 758 & 758 & 758 & 758 \\
\hline Panel B: Greek Treatment & Mean Treated & Mean Control & Mean Difference & P-Value \\
\hline Longitude & 34.42 & 32.38 & $-2.04^{* * *}$ & 0.00 \\
\hline Latitude & 39.06 & 39.56 & $0.50^{* * *}$ & 0.00 \\
\hline Average Elevation & 950.71 & 853.84 & $-96.87 * *$ & 0.01 \\
\hline Std. Elevation & 252.82 & 259.38 & 6.56 & 0.54 \\
\hline Lake & 0.33 & 0.25 & $-0.08^{* *}$ & 0.01 \\
\hline Sea & 0.25 & 0.18 & $-0.07^{* *}$ & 0.02 \\
\hline Major Rivers & 0.26 & 0.31 & $0.06^{*}$ & 0.09 \\
\hline Temperature & 0.01 & 0.01 & $-0.00 * *$ & 0.04 \\
\hline Precipitation & 0.61 & 0.68 & $0.07^{* * *}$ & 0.00 \\
\hline Suitability to Cultivation & 4.13 & 4.24 & 0.12 & 0.33 \\
\hline$N$ & 758 & 758 & 758 & 758 \\
\hline Panel C: Greek Treatment (Trimmed) & Mean Treated & Mean Control & Mean Difference & P-Value \\
\hline Longitude & 32.72 & 32.59 & -0.13 & 0.68 \\
\hline Latitude & 39.29 & 39.52 & $0.23^{*}$ & 0.06 \\
\hline Average Elevation & 885.06 & 913.28 & 28.23 & 0.47 \\
\hline Std. Elevation & 251.44 & 252.05 & 0.61 & 0.96 \\
\hline Lake & 0.28 & 0.26 & -0.03 & 0.47 \\
\hline Sea & 0.31 & 0.19 & $-0.12^{* * *}$ & 0.00 \\
\hline Major Rivers & 0.24 & 0.28 & 0.04 & 0.32 \\
\hline Temperature & 0.01 & 0.01 & -0.00 & 0.10 \\
\hline Precipitation & 0.63 & 0.64 & 0.02 & 0.33 \\
\hline Suitability to Cultivation & 4.24 & 4.32 & 0.08 & 0.54 \\
\hline$N$ & 602 & 602 & 602 & 602 \\
\hline
\end{tabular}

Notes: This table reports mean difference tests for exogenous covariates by minority treatment indicators. Minority treatment indicators are set to one for districts with above median minority shares after having filtered out the subregion fixed effects. Panel A reports mean difference tests by Armenian Treatment Indicator. Panel B reports mean difference tests by Greek Treatment indicator. Panel C reports mean difference tests by at the 1 percent level, $* *$ at the 5 percent level, and ${ }^{*}$ at the 10 percent level. 
Table S.3: Minority Presence and Average Luminosity, Matching Estimates: Robustness of the results in Table 7 to alternative propensity score matching methods

\begin{tabular}{|c|c|c|c|c|c|}
\hline & (1) & (2) & (3) & $(4)$ & (5) \\
\hline & \multicolumn{5}{|c|}{ Propensity Score Matching } \\
\hline & $\begin{array}{l}\text { Nearest Neighbour } \\
\text { (Equal Weights) }\end{array}$ & Radius $(\mathrm{r}=0.1)$ & $\begin{array}{c}\text { Gaussian } \\
\text { Kernel }\end{array}$ & $\begin{array}{c}\text { Epanechnikov } \\
\text { Kernel }(\mathrm{bw}=0.06)\end{array}$ & $\begin{array}{c}\text { Epanechnikov } \\
\text { Kernel }(b w=0.04)\end{array}$ \\
\hline & \multicolumn{5}{|c|}{ Panel A: Armenian Treatment Estimates (Dep.Var.: Log Average Luminosity in 2000) } \\
\hline Armenian Treatment & 0.239 & 0.274 & 0.264 & 0.255 & 0.26 \\
\hline Armenian Treatment (Bias Adjusted) & 0.215 & 0.273 & 0.259 & 0.256 & 0.235 \\
\hline Bootstrapped Standard Errors & {$[0.106]^{* *}$} & {$[0.076]^{* * *}$} & {$[0.083]^{* * *}$} & {$[0.067]^{* * *}$} & {$[0.067]^{* * *}$} \\
\hline Analytical Standard Errors & $(0.100)^{* *}$ & $(0.078)^{* * *}$ & - & - & - \\
\hline Treatment Districts & 372 & 372 & 372 & 372 & 372 \\
\hline Control Districts & 201 & 379 & 379 & 379 & 379 \\
\hline Common Support & Yes & Yes & Yes & Yes & Yes \\
\hline Balancing Property Satisfied & Yes & Yes & Yes & Yes & Yes \\
\hline Observations & 573 & 751 & 751 & 751 & 751 \\
\hline
\end{tabular}

Panel B: Greek Treatment Estimates (Dep.Var.: Log Average Luminosity in 2000)

Greek Treatment

Greek Treatment (Bias Adjusted)

0.342
0.368
$[0.100]^{* * *}$
$(0.110)^{* * *}$
279
152
Yes
Yes
431

0.43
0.418
$[0.080]^{* * *}$
$(0.086)^{* * *}$
279
322
Yes
Yes
601

0.37
0.386
$[0.091]^{* * *}$
-
279
322
Yes
Yes
601

0.349
0.341
$[0.081]^{* * *}$
-
279
322
Yes
Yes
601

0.353

0.348

Bootstrapped Standard Errors

Analytical Standard Errors

Treatment District

Common Support

Balancing Property Satisfied

Observations

431

601

$[0.083]^{* * *}$

Notes: This table presents the propensity score matching estimates of the average treatment effect of the Armenian and Greek treated districts (ATT), in Panels A and B respectively. Armenian and Greek Treatment indicators are equal to one for above median shares of respective distritilion The be fea, rive for thall

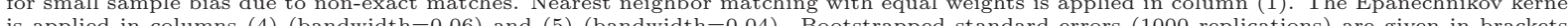
is applied * at the 10 percent level. 
TABle S.4: Minority Presence and Average Luminosity: Further robustness checks for matching estimates, Robustness to alternative treatment definitions

\begin{tabular}{|c|c|c|c|c|c|c|c|}
\hline \multirow[t]{2}{*}{$\begin{array}{l}\text { Panel A: Robustness to alternative treatment definitions } \\
\text { Treatment }=1 \text { if minority share is above the sample median of the raw data }\end{array}$} & \multirow{2}{*}{$\begin{array}{l}(1) \\
\text { OLS }\end{array}$} & \multirow{2}{*}{$\begin{array}{l}(2) \\
\text { OLS }\end{array}$} & \multirow{2}{*}{$\begin{array}{c}\text { (3) } \\
\text { Covariate Matching } \\
\text { Nearest Neighbour }\end{array}$} & \multicolumn{4}{|c|}{ Propensity Score Matching } \\
\hline & & & & Nearest Neighbour & Radius $(\mathrm{r}=0.05)$ & Kernel $(\mathrm{bw}=0.02)$ & $\begin{array}{c}\text { (7) } \\
\text { Stratification }\end{array}$ \\
\hline & \multicolumn{7}{|c|}{ Armenian Treatment Estimates } \\
\hline Armenian Treatment & 0.358 & 0.338 & 0.299 & 0.219 & 0.312 & 0.293 & 0.29 \\
\hline Armenian Treatment (Bias Adjusted) & & & 0.232 & 0.179 & 0.307 & 0.278 & 0.28 \\
\hline Bootstrapped Standard Errors & {$[0.116] * * *$} & {$[0.110] * * *$} & & {$[0.115]^{*}$} & {$[0.088] * * *$} & {$[0.089]^{* * *}$} & {$[0.086]^{* * *}$} \\
\hline Analytical Standard Errors & $(0.112)^{* * * *}$ & $(0.107)^{* * *}$ & $(0.097)^{* * *}$ & $(0.109)^{* *}$ & $(0.086)^{* * * *}$ & - & - \\
\hline Treatment Districts & & & 313 & 313 & 313 & 313 & 313 \\
\hline Control Districts & & & 290 & 161 & 290 & 290 & 290 \\
\hline Common Support & No & Yes & Yes & Yes & Yes & Yes & Yes \\
\hline Balancing Property Satisfied & & & & Yes & Yes & Yes & Yes \\
\hline \multirow[t]{2}{*}{ Observations } & 758 & 603 & 603 & 474 & 603 & 603 & 603 \\
\hline & \multicolumn{7}{|c|}{ Greek Treatment Estimates } \\
\hline Greek Treatment & 0.482 & 0.552 & 0.44 & 0.582 & 0.565 & 0.539 & 0.567 \\
\hline Greek Treatment (Bias Adjusted) & & & 0.44 & 0.598 & 0.574 & 0.55 & 0.56 \\
\hline Bootstrapped Standard Errors & {$[0.107]^{* * * *}$} & {$[0.136] * * *$} & & {$[0.172]^{* * *}$} & {$[0.108]^{* * *}$} & {$[0.141]^{* * *}$} & {$[0.119]$ **** } \\
\hline Analytical Standard Errors & $(0.107) * * *$ & $(0.139)^{* * * *}$ & $(0.135)^{* * *}$ & $(0.147)^{* * *}$ & $(0.110)^{* * * *}$ & - & $(0.116)^{* * *}$ \\
\hline Treatment Districts & & & 154 & 154 & 153 & 154 & 154 \\
\hline Control Districts & & & 153 & 83 & 153 & 153 & 153 \\
\hline Common Support & No & Yes & Yes & Yes & Yes & Yes & Yes \\
\hline Balancing Property Satisfied & & & & Yes & Yes & Yes & Yes \\
\hline Observations & 758 & 307 & 307 & 237 & 306 & 307 & 307 \\
\hline \multirow{3}{*}{$\begin{array}{l}\text { Panel B: Robustness to alternative treatment definitions } \\
\text { Treatment }=1 \text { if minority share is above } 1 \%\end{array}$} & (1) & (2) & $\stackrel{(3)}{\text { Covariate Matching }}$ & \multicolumn{4}{|c|}{$\begin{array}{c}(5) \\
\text { Propensity Score Matching }\end{array}$} \\
\hline & OLS & OLS & Nearest Neighbour & Nearest Neighbour & Radius $(\mathrm{r}=0.05)$ & Kernel $(\mathrm{bw}=0.02)$ & Stratification \\
\hline & \multicolumn{7}{|c|}{ Armenian Treatment Estimates } \\
\hline Armenian Treatment & 0.269 & 0.27 & 0.189 & 0.202 & 0.279 & 0.202 & 0.236 \\
\hline Armenian Treatment (Bias Adjusted) & & & 0.149 & 0.191 & 0.28 & 0.201 & 0.236 \\
\hline Bootstrapped Standard Errors & {$[0.110]^{* *}$} & {$[0.107]^{* *}$} & & {$[0.094]^{* *}$} & {$[0.080]^{* * *}$} & {$[0.079]^{* * *}$} & {$[0.086]^{* * *}$} \\
\hline Analytical Standard Errors & $(0.108)^{* *}$ & $(0.108)^{* * *}$ & $(0.089)^{*}$ & $(0.109)^{*}$ & $(0.083)^{* * * *}$ & - & $(0.084)^{* * * *}$ \\
\hline Treatment Districts & & & 477 & 477 & 477 & 477 & 477 \\
\hline Control Districts & & & 275 & 175 & 275 & 275 & 275 \\
\hline Common Support & No & Yes & Yes & Yes & Yes & Yes & Yes \\
\hline Balancing Property Satisfied & $=$ & - & - & Yes & Yes & Yes & Yes \\
\hline \multirow[t]{2}{*}{ Observations } & 758 & 752 & 752 & 652 & 752 & 752 & 752 \\
\hline & \multicolumn{7}{|c|}{ Greek Treatment Estimates } \\
\hline Greek Treatment & 0.429 & 0.393 & 0.317 & 0.444 & 0.496 & 0.488 & 0.509 \\
\hline Greek Treatment (Bias Adjusted) & & & 0.36 & 0.415 & 0.497 & 0.489 & 0.506 \\
\hline Bootstrapped Standard Errors & {$[0.099]^{* * *}$} & {$[0.116]^{* * *}$} & & {$[0.174]^{* *}$} & {$[0.118]^{* * *}$} & {$[0.145]^{* * *}$} & {$[0.139]^{* * *}$} \\
\hline Analytical Standard Errors & $(0.096)^{* * * *}$ & $(0.117)^{* * * *}$ & $(0.137)^{* * *}$ & $(0.150)^{* * *}$ & $(0.117)^{* * *}$ & 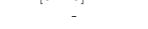 & - \\
\hline Treatment Districts & & & 185 & 185 & 184 & 185 & 184 \\
\hline Control Districts & & & 145 & 89 & 144 & 145 & 146 \\
\hline Common Support & No & Yes & Yes & Yes & Yes & Yes & Yes \\
\hline Balancing Property Satisfied & - & - & - & Yes & Yes & Yes & Yes \\
\hline Observations & 758 & 330 & 330 & 274 & 328 & 330 & 330 \\
\hline
\end{tabular}

Notes: This table presents the covariate and propensity score matching estimates of the average treatment effect of the Armenian and Greek treated districts (ATT). In Panel A, Armenian and Greek Treatment indicators are equal to one for above median shares of respective distributions of the raw data. In Panel B, Armenian and Greek Treatment indicators are equal to one for above $1 \%$ shares of respective distributions of the raw data. The baseline exogenous variables that are used in the matching procedure are longitude, latitude, elevation, standard deviation of elevation, lake, sea, river dummies, temperature, precipitation, and suitability to cultivation. To ensure that balancing property is satisfied, we trim the sample for the Armenian treatment to the propensity score interval of [0.3,0.7] in Panel A, and for the Greek treatment to the propensity score interval of $[0.4,0.6]$ in Panel A and to $[0.3,0.7]$ in Panel B. We show two sets of ATT estimates that are either uncorrected or corrected for small sample bias due to non-exact matches. Nearest neighbor matching with random draw is applied in column (4). The Epanechnikov kernel (bandwidth=0.02) is applied in column (6). Bootstrapped standard errors (1000 replications) are given in brackets, while analytical standard errors are given in parentheses (both type of standard errors are clustered at the province level for OLS). *** denotes statistical significance at the 1 percent level, ** at the 5 percent level, and * at the 10 percent level. 